\title{
Sweden: Financial Sector Assessment Program Update-Detailed Assessment of Observance on Insurance Core Principles
}

This Detailed Assessment of Observance on Insurance Core was prepared by a staff team of the International Monetary Fund as background documentation for the periodic consultation with the member country. It is based on the information available at the time it was completed in September, 2011. The views expressed in this document are those of the staff team and do not necessarily reflect the views of the government of Sweden or the Executive Board of the IMF.

The policy of publication of staff reports and other documents by the IMF allows for the deletion of market-sensitive information.

Copies of this report are available to the public from

International Monetary Fund • Publication Services

$70019^{\text {th }}$ Street, N.W. • Washington, D.C. 20431

Telephone: (202) 623-7430 • Telefax: (202) 623-7201

E-mail: publications@imf.org Internet: http://www.imf.org

\section{International Monetary Fund Washington, D.C.}


FinANCIAL SECtor Assessment Program UPdate

\section{SWEDEN}

INSURANCE CORE PRINCIPLES

\section{DETAILED ASSESSMENT OF OBSERVANCE}

SEPTEMBER 2011 
Glossary 3



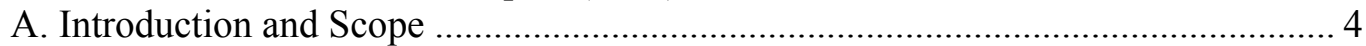

B. Information and Methodology Used for Assessment............................................. 4

C. Overview - Institutional and Macro Prudential Setting ..................................... 5

Market Structure and Industry Performance ................................................. 5

Institutional Framework and Arrangements ................................................. 13

Key Findings and Recommendations ................................................... 14

II. Detailed Principle-by-Principle Assessment Methodology ............................................. 24

Tables

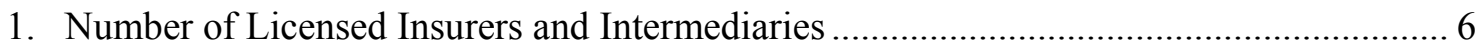

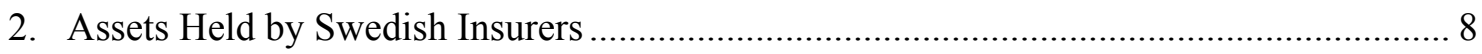

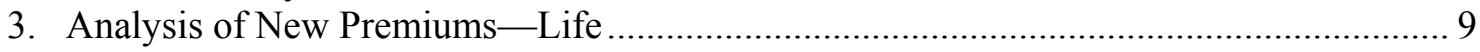

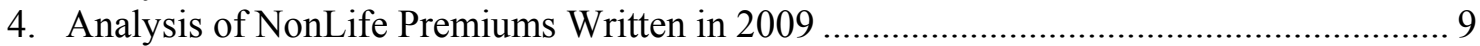

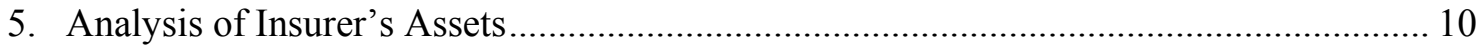

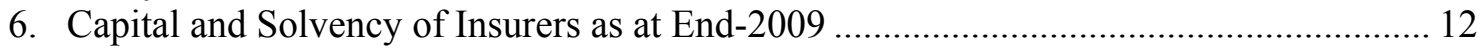

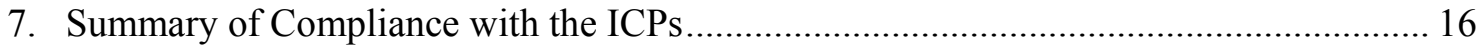

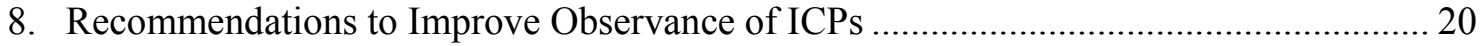

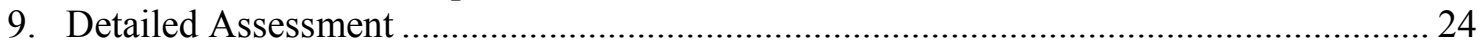

Figures

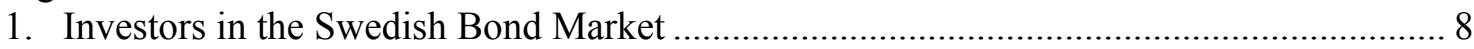

2. The Yield on 10-Year Swedish Government Bond, 10-Year Swedish Interest Rate

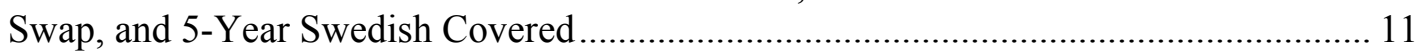

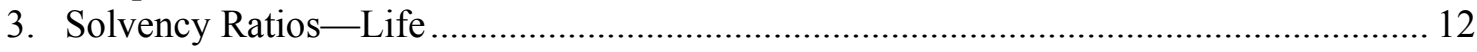

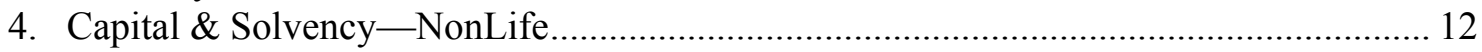

Appendix

I. Key Recommendations of the 2002 FSAP and Their Implementation............................ 72 


\section{GLOSSARY}

\begin{tabular}{|c|c|}
\hline AML-CFT & Anti-Money Laundering and Combating the Financing of Terrorism \\
\hline ARA & Annual Reports Act \\
\hline ARIUA & Annual Reports for Insurance Undertakings Act \\
\hline ARN & National Board for Consumer Complaints \\
\hline CDD & Customer due diligence \\
\hline CEIOPS & $\begin{array}{l}\text { Committee of European Insurance and Occupational Pensions } \\
\text { Supervisors }\end{array}$ \\
\hline CIB & The Swedish Consumers' Insurance Bureau \\
\hline DG & Director-General \\
\hline FAFT & Financial Action Task Force \\
\hline $\mathrm{FF}$ & Swedish Insurance Federation (Försäkringsförbundet) \\
\hline FI & Finansinspektionen (Swedish FSA) \\
\hline FIBA & Foreign Insurance Business Act \\
\hline EEA & European Economic Area \\
\hline EU & European Union \\
\hline $\mathrm{FIO}$ & Financial Supervisory Authority Instructions Ordinance \\
\hline FSAP & Financial Sector Assessment Program \\
\hline IBA & Insurance Business Act (1982:713), Försäkringsrörelselagen \\
\hline IAIS & International Association of Insurance Supervisors \\
\hline ICA & Insurance Contracts Act \\
\hline ICPs & Insurance Core Principles \\
\hline IFRS & International Financial Reporting Standards \\
\hline IMF & International Monetary Fund \\
\hline $\mathrm{MD}$ & Managing Director \\
\hline MoU & Memorandum of Understanding \\
\hline MoF & Ministry of Finance \\
\hline MLTFO & Money Laundering and Terrorist Financing Ordinance \\
\hline MTFs & Multilateral Trading Facilities \\
\hline RPA & Rights of Priority Act \\
\hline SCA & Swedish Consumer Agency \\
\hline SECA & Swedish Economic Crime Authority \\
\hline Secrecy Act & Public Access to Information and Secrecy Act (2009:400) \\
\hline SIG & Swedish Instrument of Government \\
\hline SIMA & Swedish Insurance Mediation Act \\
\hline SNDO & Swedish National Debt Office \\
\hline SOU & Statens Offentliga Utredningar \\
\hline SSFCA & Supplementary Supervision of Financial Conglomerates Act \\
\hline STR & Suspicious Transactions Reports \\
\hline ULP & Unit-Linked Policies \\
\hline
\end{tabular}




\section{Assessment of Insurance Core Principles}

\section{A. Introduction and Scope}

1. This assessment provides an update on the significant regulatory and supervisory developments in the insurance sector of Sweden since 2002. The current assessment was conducted by Su Hoong Chang (Insurance Supervision Advisor contracted by the International Monetary Fund (IMF)) during March 9-22, 2011. Sweden undertook an initial Financial Sector Assessment Program (FSAP) in 2002, which included a formal assessment of its observance with the Insurance Core Principles (ICPs) issued by the International Association of Insurance Supervisors (IAIS) in 2000. The Swedish authorities have largely addressed the recommendations arising from the 2002 assessment (Appendix 1).

\section{The current assessment is benchmarked against the ICPs issued by the}

IAIS in 2003. This update assessment also took account of the relevant IAIS standards and guidance that complements the ICPs, including the ICP materials adopted by the IAIS in October 2010. ${ }^{1}$ These are noted by way of additional comments, where appropriate, and have no impact on the rating of the ICPs.

\section{B. Information and Methodology Used for Assessment}

3. The level of observance for each ICP reflects the assessment of the essential criteria only. Advanced criteria are not taken into consideration in assessing observance of the ICPs but are noted, where applicable. Each ICP is rated in terms of the level of observance as follows:

- "Observed"-where all the essential criteria are observed or where all the essential criteria are observed except for those that are considered not applicable.

- "Largely observed" - where only minor shortcomings exist, which do not raise any concerns about the authorities' ability to achieve full observance.

- "Partly observed"-where, despite progress, the shortcomings are sufficient to raise doubts about the authorities' ability to achieve observance.

- "Not observed"-where no substantive progress toward observance has been achieved.

4. The assessment is based solely on the laws, regulations and other supervisory requirements and practices that are in place at the time of the assessment. Ongoing regulatory initiatives are noted by way of additional comments.

\footnotetext{
${ }^{1}$ At the time of assessment, the IAIS was in the process of updating the ICPs and the corresponding standards, and guidance material. The IAIS has issued some ICP materials at its October 2010 general meeting, which may be revised for alignment and consistency when the revised ICP will be adopted in October 2011.
} 
In particular, the parliament has passed a new Insurance Business Act (IBA), which will come into effect on April 1, 2011. A comprehensive self-assessment and other pertinent information provided by the authorities facilitated the assessment. The assessor also met a number of Swedish insurers as well as industry and professional associations, and has benefitted from their valuable inputs and insightful views.

5. The assessor is grateful to the authorities for the full cooperation, thoughtful logistical arrangements and co-coordination of various meetings with industry participants. In-depth discussions with and briefings by officials from the Swedish Financial Supervisory Authority (FI) facilitated a robust and meaningful assessment of the Swedish regulatory and supervisory regime for the insurance sector.

\section{Overview-Institutional and Macro Prudential Setting}

\section{Market Structure and Industry Performance}

6. The insurance sector in Sweden is well developed and mature, with an insurance density (premium per capita) of US\$3,540 and insurance penetration of 8.2 percent, compared to the average for Europe of US\$1,862 and 7.6 percent, respectively. ${ }^{2}$ Around 50 percent of household financial assets are held in life insurance products. ${ }^{3}$ The insurance industry had about 19,700 employees as at end-2009, of which more than 14,000 were employed by nonlife insurers.

7. The total number of insurers conducting business in Sweden has remained relatively stable (Table 1 ). The net reduction of 9 insurers over the five years period from 2006 to 2010 was mainly attributable to a significant increase of 20 captive insurers, offset by the exit of 17 nonlife insurers and 14 livestock insurers. There have been a number of acquisitions since $2004,{ }^{4}$ with increasing level of foreign ownership. Prior to 2000, life insurers offering unit-linked policies (ULP) were required to set up specialized unit-linked insurance companies. Although this requirement had since been waived, most life insurers still maintain their unit-linked subsidiaries. Friendly societies are small insurers owned by policyholders and some societies insure occupational pension funds. Livestock insurers are also small players, with aggregate assets of about SEK10 million as at end-2010.

8. The captive insurance segment has grown markedly over the last $\mathbf{1 0}$ years, driven mainly by tax advantages. Captive insurers are typically owned by large commercial groups and municipalities to insure/reinsure selected intra-group risks. About 130 Swedish industrial groups have established captives, of which 30 are

\footnotetext{
${ }^{2}$ Swiss Re Sigma 2/10.

${ }^{3}$ Swedish Insurance Federation.

${ }^{4} 2006$ - Skandia (a life insurer) was acquired by Old Mutual plc of U.K. and South Africa. 2007 - SPP (an occupational pension insurer) was acquired by Storebrand ASA of Norway. 2009 - TrygVesta of Denmark acquired Moderna (a nonlife insurer), which now operates as a Swedish branch.
} 
domiciled in Sweden. Factors contributing to the growth of captives include legislative amendment facilitating licensing of captives and deferral of tax in respect of premiums paid to captive (re)insurers. In addition, captive subsidiaries of Swedish parents are eligible to make tax-free transfers to/from their parents. Of the 49 licensed captives as at end-2009, 33 are pure captives, i.e., they do not write any third party liability risks while 16 captives write liability insurance involving third party claimants, mainly general liability insurance and some third party motor liability insurance. Eight of the captives are licensed to write direct insurance and four are authorized to conduct reinsurance activities while the rest conduct both direct and reinsurance business.

Table 1. Sweden: Number of Licensed Insurers and Intermediaries

\begin{tabular}{lrrrrr}
\hline As at end of: & $\mathbf{2 0 0 6}$ & $\mathbf{2 0 0 7}$ & $\mathbf{2 0 0 8}$ & $\mathbf{2 0 0 9}$ & $\mathbf{2 0 1 0}$ \\
\hline Domestic insurers & & & & & \\
$\quad$ Life insurance & 32 & 33 & 33 & 33 & 33 \\
$\quad$ Nonlife insurance & 174 & 157 & 159 & 146 & 157 \\
$\quad$ Unit-linked & 12 & 11 & 10 & 9 & 10 \\
$\quad$ Reinsurance & 3 & 5 & 5 & 5 & 5 \\
$\quad$ Captive insurance & 29 & 41 & 46 & 49 & 49 \\
$\quad$ Friendly societies & 81 & 79 & 78 & 78 & 82 \\
$\quad$ Livestock & 111 & 104 & 101 & 95 & 97 \\
$\quad$ Sub-total & 442 & 430 & 432 & 415 & 433 \\
Association of Underwriters & 1 & 1 & 1 & 1 & 1 \\
& 443 & 431 & 433 & 416 & 434 \\
Insurance intermediaries & & & & & \\
$\quad$ Insurance mediation employees & 2,024 & 2,334 & 2,865 & 3,642 & 3,860 \\
$\quad$ Insurance mediation & 881 & 917 & 923 & 984 & 1,044 \\
& & & & & \\
Foreign branches in Sweden & 26 & 30 & 30 & 28 & 29 \\
Swedish insurers' branches abroad & 33 & 40 & 48 & 47 & 47 \\
Insurance groups & 23 & 37 & 42 & 53 & 60 \\
\hline
\end{tabular}

Source: Fl's Swedish Data - FSAP.

\section{The number of insurance intermediaries ${ }^{5}$ has increased significantly since}

2006. Sweden implemented the European Union (EU) Directive on Insurance Mediation (2002/92/EC) in 2005, which requires intermediaries to be licensed and supervised. Industry feedback suggests that it is easier to obtain an insurance intermediary license to market collective investment schemes, which contributed to the high number of insurance intermediaries. Bancassurance is one of the main distribution channels of life insurance products. Of the four large Swedish banks, three are registered as "tied intermediary" (see $\boldsymbol{I C P} 24$ ) of their related insurance subsidiaries and one is licensed as an insurance intermediary.

\footnotetext{
${ }^{5}$ Insurance intermediary is defined as a person who presents or suggests insurance contracts or carries out other preparatory work before the execution of an insurance contract; enters into insurance contracts on behalf of a third party; or provides assistance in the management and performance of insurance contracts. (Cpt 1 s 1 of SIMA).
} 
10. The Swedish insurance industry is concentrated. While there are a large number of small local nonlife insurers and friendly societies, the market is dominated by a few large insurers/groups. All major banks have insurance subsidiaries and some large insurers have their own bank subsidiaries. Notably, the number of insurance groups more than doubled from 23 to 60 , as at end-2010. ${ }^{6}$ The five largest insurance groups accounted for approximately 50 percent of total assets as at end-2009. ${ }^{7}$ The top five life insurers accounted for 61 percent of assets of the life sector while the top five nonlife insurers have about 55 percent market share in terms of gross premiums in 2009.

\section{Assets held by the insurance industry as at end-2009 totaled SEK} $\mathbf{2 , 9 6 7}$ billion, of which life and unit-linked insurers accounted for $\mathbf{7 7}$ percent (see Table 2). Assets held by insurers represented 95 percent of GDP as at end-2009. ${ }^{8}$ As at end-2009, insurers were the largest investor category in the Swedish bond market. Insurer' investments in bonds have been increasing steadily and reached SEK 1,125 billion as at end-2009 (see Figure 1), or approximately 50 percent of the total amount outstanding.

12. Life and unit-linked insurers offer a diversified range of products, the bulk of which relate to pension insurance. Traditional policies range from pure protection policies such as term insurance to policies that combine both protection and investment, i.e., savings with guarantees and where the insurer determines the investment policy and distribution of surplus. ULPs are generally issued in respect of occupational pension insurance, private pension insurance, endowment and capital pension insurance. ${ }^{9}$ ULPs are, in effect, investment products as life insurance coverage is not mandatory and policyholders bear all the investment risks. The analysis of new life insurance business is presented in Table 3. The occupational pension market is dominated by insurers owned by employers' organization and trade unions. Foreign risks written by life and unit-linked insurers are immaterial.

\section{Motor insurance is the dominant class of nonlife insurance and Swedish nonlife insurers write a significant level of foreign risks ${ }^{10}$ (see Table 4). Motor} insurances accounted for 22 percent of total premiums written in 2009 while foreign risks made up 34 percent. The dominance of motor insurance is partly attributable to the comprehensive range of social insurance and the increasing use of captive insurance

\footnotetext{
${ }^{6}$ In 2007, FI found that 47 insurers failed to report that they were part of insurance groups. (FI Report 208:16)

${ }^{7}$ Skandia, SEB, Folksam, AFA and LF Liv.

${ }^{8}$ The financial system's total assets amounted to about 550 percent of GDP, of which 65 percent belonged to the four largest banking groups.

${ }^{9}$ Some life insurers offer pension products exclusively.

${ }^{10}$ Foreign risks are those that do not qualify as Swedish risks (i.e., risks located in Sweden or where the insurers are residents in Sweden or having a permanent establishment in Sweden.)
} 
by large industrial groups. The bulk of the foreign risks were written by foreign branches of Swedish nonlife insurers. Although insurers are required to report foreign risks accepted to FI, there is no analysis of foreign risk by lines of business or geographical location. In Sweden, the market for credit insurance and surety insurances dominated by branches of European insurers.

Table 2. Sweden: Assets Held by Swedish Insurers

(In SEK millions)

\begin{tabular}{|c|c|c|c|c|}
\hline & 2006 & 2009 & Change & $\begin{array}{c}\text { Percentage } \\
\text { Share of } \\
\text { Total }\end{array}$ \\
\hline Life insurance & $1,749,656$ & $1,853,027$ & 103,371 & 62 \\
\hline Nonlife insurance & 503,514 & 541,712 & 38,198 & 18 \\
\hline Unit-linked policies & 346,927 & 436,416 & 89,489 & 15 \\
\hline Reinsurance & 6,183 & 8,873 & 2,689 & 0 \\
\hline Captive insurance & 11,322 & 21,609 & 10,286 & 1 \\
\hline Friendly societies & 129,001 & 105,567 & $(23,434)$ & 4 \\
\hline & $2,746,604$ & $2,967,203$ & 220,599 & 100 \\
\hline $\begin{array}{l}\text { Percentage of } \\
\text { nominal GDP }\end{array}$ & 93 & 95 & & \\
\hline
\end{tabular}

Source: Fl's Swedish Data - FSAP.

Figure 1. Sweden: Investors in the Swedish Bond Market

(In SEK billions)

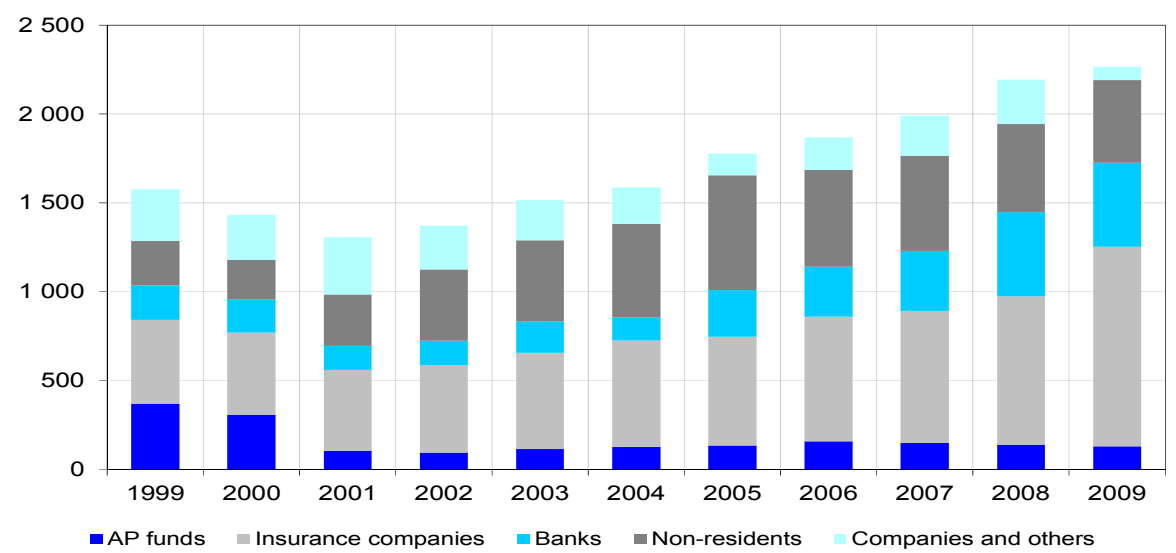

Source: Riksbanken, the Swedish financial market 2010. 
Table 3. Sweden: Analysis of New Premiums-Life

(In SEK millions)

\begin{tabular}{lrrrr}
\hline & 2006 & 2007 & 2008 & 2009 \\
\hline Traditional & 80,104 & 80,630 & 88,802 & 91,781 \\
& $59 \%$ & $62 \%$ & $63 \%$ & $60 \%$ \\
Unit-linked & & & & \\
& 55,030 & 49,594 & 52,357 & 60,548 \\
& $41 \%$ & $38 \%$ & $37 \%$ & $40 \%$ \\
\hline
\end{tabular}

Source: Fl's Swedish Data - FSAP.

Table 4. Sweden: Analysis of NonLife Premiums Written in 2009

\begin{tabular}{|l|r|r|r|r|}
\hline & Gross & Percentage & Net & $\begin{array}{r}\text { Retention } \\
\text { Percent }\end{array}$ \\
\hline Motor third party (mandatory) & 8,807 & 9 & 8,421 & 96 \\
\hline Motor - others & 12,838 & 13 & 12,403 & 97 \\
\hline Business and houseowner & 12,821 & 13 & 10,433 & 81 \\
\hline Household and homeowner & 11,671 & 12 & 9,978 & 85 \\
\hline Accident \& health & 5,968 & 6 & 5,639 & 94 \\
\hline Foreign risks & 32,704 & 34 & 27,363 & 84 \\
\hline Others * & 11,163 & 12 & 8,866 & 79 \\
\hline & 95,972 & 100 & 83,104 & 87 \\
\hline
\end{tabular}

Source: Fl's Swedish Data - FSAP.

* Others include marine, credit, aviation and animal insurances.

14. Insurers' investments are mainly concentrated in bonds and equities, representing 37 percent and 52 percent of total assets as at end-2010, respectively (Table 5). In particular, life insurers held 56 percent of their assets in equities (mainly in respect of ULPs) and are heavily exposed to equity risk, as evidenced during the crisis in 2008. Their equity portfolios have recovered with the market rebound since 2009. Investments in equities rose by another 15 percent (SEK 202 billion) in 2010 to reach SEK 1,539 billion as at end-2010, partly attributable to higher market valuation. The significant bond portfolios expose life insurers to interest rate risks.

15. Both life and nonlife insurers are susceptible to developments in global financial markets through their holdings of foreign investments, which totaled SEK 933 billion (32 percent of total assets) as at end-2010. Swedish insurers held approximately SEK 665 billions of sovereign bonds as at end-2009, of which 78 percent were issued by Swedish government. Another 9 percent and 7 percent were issued by authorities in Germany and the United States, respectively. The level of sovereign bond has remained largely unchanged in 2010, and the main exposure was to German sovereign bonds. 
16. Life insurers' investments are sensitive to interest rate changes, but the impact is even greater on their technical provisions. Long-term interest rates have been declining and reached a record low in 2010 (Figure 2). Lower interest rates increase insurers' technical provisions mainly due to the discounting rate used to calculate the present value of insurers' policy commitments. On the asset side, there are reinvestment risks due to scarcity of suitable long-term investments ${ }^{11}$ to match their long-term commitments. Swedish life insurers invest more than 30 percent of their assets in debt securities, with significantly shorter maturities compared to their long-term liabilities. Based on FI's calculation in 2009, a one percent decrease in interest rates for all maturities would mean an increase in the value of life insurers' liabilities by around SEK 150 billion. The Swedish interest-bearing assets would only increase SEK 35 billion, so the net effect would be SEK115 billion given a one percent decrease in the discount rate. ${ }^{12}$

Table 5. Sweden: Analysis of Insurer's Assets

\begin{tabular}{|c|c|c|c|c|c|c|}
\hline & 2009 & & & 2010 & & \\
\hline & & & Of which & & & Of which \\
\hline & in 'SEK mn & & Foreign & in 'SEK mn & & Foreign \\
\hline \multicolumn{7}{|c|}{ Life \&Unit Linked ${ }^{1}$} \\
\hline Bonds & 846,567 & $38 \%$ & 269,785 & 830,255 & $34 \%$ & 255,888 \\
\hline Equities & $1,186,032$ & $53 \%$ & 441,226 & $1,366,685$ & $56 \%$ & 472,695 \\
\hline Real estate & 47,957 & $2 \%$ & 7,410 & 50,235 & $2 \%$ & 6,559 \\
\hline \multirow[t]{2}{*}{ Others } & 157,894 & $7 \%$ & 10,428 & 204,535 & $8 \%$ & NA \\
\hline & $2,238,450$ & $100 \%$ & 728,849 & $2,451,710$ & $100 \%$ & 735,142 \\
\hline Nonlife & & & $33 \%$ & & & $30 \%$ \\
\hline Bonds & 267,023 & $55 \%$ & 67,867 & 256,540 & $52 \%$ & 69,774 \\
\hline Equities & 150,472 & $31 \%$ & 59,668 & 172,731 & $35 \%$ & 67,165 \\
\hline Real estate & 14,963 & $3 \%$ & 6 & 16,175 & $3 \%$ & 5 \\
\hline \multirow[t]{3}{*}{ Others } & 52,777 & $11 \%$ & 7,029 & 52,354 & $11 \%$ & NA \\
\hline & 485,235 & $100 \%$ & 134,570 & 497,800 & $100 \%$ & 136,944 \\
\hline & & & $28 \%$ & & & $28 \%$ \\
\hline \multicolumn{7}{|l|}{ Total } \\
\hline Bonds & $1,113,590$ & $41 \%$ & 337,652 & $1,086,794$ & $37 \%$ & 325,662 \\
\hline Equities & $1,336,504$ & $49 \%$ & 500,894 & $1,539,416$ & $52 \%$ & 539,860 \\
\hline Real estate & 62,920 & $2 \%$ & 7,416 & 66,410 & $2 \%$ & 6,564 \\
\hline \multirow[t]{3}{*}{ Others } & 210,671 & $8 \%$ & 17,457 & 256,890 & $9 \%$ & NA \\
\hline & $2,723,685$ & $100 \%$ & 863,419 & $2,949,510$ & $100 \%$ & 933,304 \\
\hline & & & $32 \%$ & & & $32 \%$ \\
\hline
\end{tabular}

Source: Swedish Insurance in Figures by Statistics of Sweden.

Note 1: This analysis includes investments of ULPs totaling SEK 578,386 million.

${ }^{11}$ The average maturity of life insurers' assets is typically shorter than their liabilities, which can stretch more than 40 years, e.g., whole life policies or annuities. Maturing assets have to be reinvested and there is a risk the interest rate of the new investment may be lower than anticipated.

${ }^{12}$ Risks in the Financial System 2009, FI. 
Figure 2. Sweden: The Yield on 10-Year Swedish Government Bond, 10-Year Swedish Interest Rate Swap, and 5-Year Swedish Covered Bond

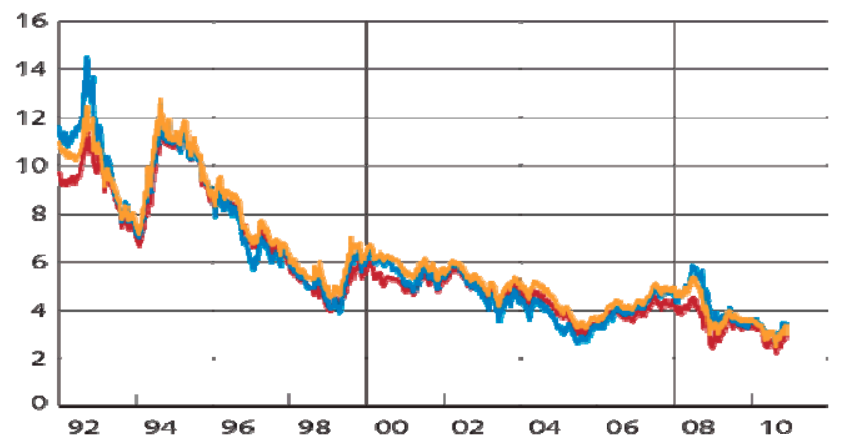

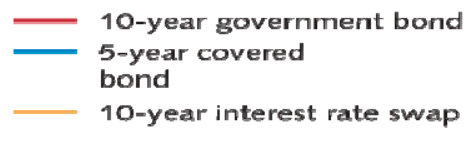

Source: Reuters EcoWin

Source: Financial Stability Report 2/2010, Riksbank.

\section{Insurers' solvency levels were hit badly in 2008 but recovered in 2009}

(Table 6). Life insurers' solvency was hit badly in 2008 due to a combination of falling asset prices and a sharp fall in interest rates. ${ }^{13}$ While their solvency ratios have recovered somewhat in 2009 (Figure 3), some life insurers are close to solvency intervention level and are monitored by FI closely. While the impact of the financial crisis on nonlife insurers was more moderate, both the overall operating income and solvency ratio dropped in 2008. The overall solvency ratio for nonlife insurers improved in 2009 and FI's assessment is that there is only a minor solvency risk ${ }^{14}$ (Figure 4). In contrast, the solvency ratios for reinsurers and captives have been declining since 2007, and a number of captive insurers are subject to closer monitoring by FI. Notably, the reported solvency ratios are computed under the Solvency I regime and not sufficiently risk-sensitive. FI supplements its solvency assessment using the Traffic Light model through prescribed stress testing (details under ICP 23).

\section{The key risks for nonlife insurers include intense competition and}

exposures to catastrophic risks. Competition amongst the many players in the

Swedish nonlife insurance industry exerts significant pressures on their premium ratings. FI noted that over the period 2005 to 2008, nonlife insurers experienced a real decrease in earned premiums after adjusting for inflation. ${ }^{15}$ While some insurers have already exited the market in the last few years, enhanced regulatory requirements for governance and risk management under the EU Solvency II regime to be implemented in 2013 may lead to further industry consolidation. Nonlife insurers' exposures to catastrophic weather conditions are not negligible and insurers expect increasing risk

\footnotetext{
${ }^{13}$ Overall, life insurers recorded a net loss in 2008 with a negative return-on-equity of 48 percent.

${ }^{14}$ As of June 30, 2010, 68 percent of nonlife insurers had a solvency ratio of more than five. A small number of insurers reported a solvency ratio of less than two. No insurer had a solvency ratio under one. Stress tests under the Traffic Light model also showed that nonlife insurers have good margins and a relatively stable ratio of more than 3 , on average.

${ }^{15}$ Risk in Financial System 2009, FI.
} 
exposures to catastrophic weather conditions. Insurers may limit their exposure through policy conditions, which could also be cushioned by contingency reserves held as part of their own funds. Going forward, new business opportunities are mainly in products bordering the social insurance system.

Table 6. Sweden: Capital and Solvency of Insurers as at End-2009

(In SEK millions)

\begin{tabular}{|c|c|c|c|c|c|c|}
\hline & Life & Unit-linked & Nonlife & RI & Captive & Total \\
\hline Share capital & 619,967 & 22,795 & 138,692 & 1,627 & 10,303 & 793,385 \\
\hline Subordinated loans & 3,029 & 100 & 4,588 & 0 & 9 & 7,726 \\
\hline Technical provisions & $1,129,019$ & 401,576 & 330,377 & 5,644 & 6,823 & $1,873,438$ \\
\hline Other reserves & 1,613 & 1,120 & 9,369 & 9 & 13 & 12,124 \\
\hline \multirow[t]{2}{*}{ Other liabilities } & 99,549 & 10,825 & 58,683 & 1,592 & 4,461 & 175,111 \\
\hline & $1,853,178$ & 436,416 & 541,709 & 8,873 & 21,609 & $2,861,784$ \\
\hline \multicolumn{7}{|l|}{ Solvency ratio* } \\
\hline 2008 & 7.18 & 4.29 & 6.72 & 2.76 & 7.97 & \\
\hline 2009 & 13.70 & 4.68 & 9.48 & 2.63 & 6.92 & \\
\hline
\end{tabular}

Source: Fl's Swedish Data - FSAP.

*Solvency ratio = available solvency margin/required solvency margin.

Figure 3: Sweden Solvency Ratios—Life

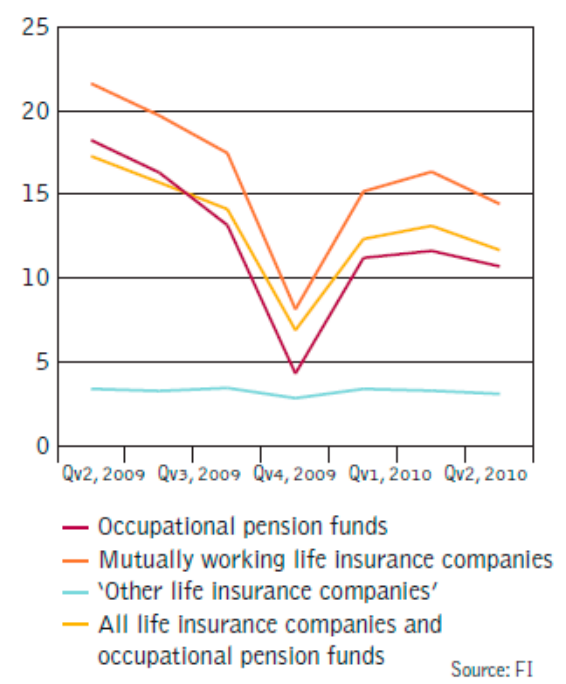

Figure 4. Sweden: Capital \& Solvency-NonLife

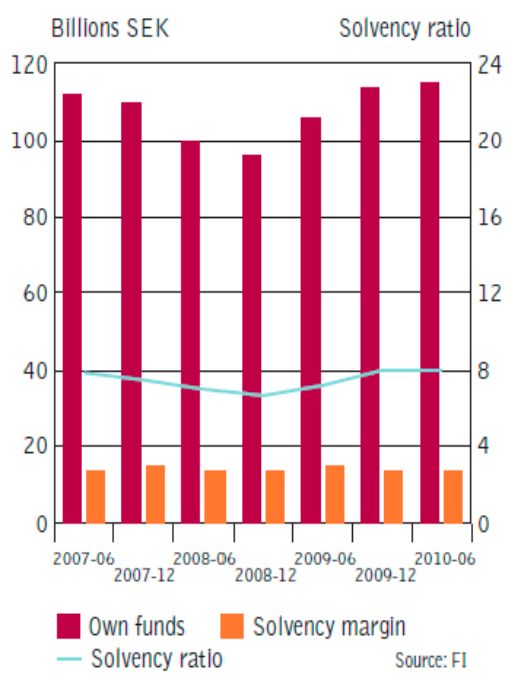

Source: Risk in Financial System October 2010, FI.

\section{A prolonged low interest climate is a significant challenge for life insurers,} with risks of unintended consequences arising from their investment strategies. Life insurers are exposed to interest rate risks on both the asset and liability sides of their balance sheets (paragraph 16 above). In particular, FI noted that insurance savings invested in life insurers and occupational pension funds amounted to SEK1,900 billion as at end-2009. More than 70 percent of these savings are linked to commitments based 
on long-term interest rate guarantees. ${ }^{16}$ A potential concern is that if insurers decide to manage their financial risks by selling shares and purchasing interest-bearing assets, it would put more downward pressure on both the stock market and interest rates resulting in a vicious circle. Such a scenario may also have systemic implications for other financial market participants. ${ }^{17}$ Life insurers are also confronting intensive competition from other investment products, compounded by the eroding tax advantage they used to enjoy.

\section{Institutional Framework and Arrangements}

\section{FI is the integrated supervisor for the financial sector in Sweden,} supervising about 3,700 entities: banks, credit institutions, investment firms, fund managers, trading platforms, exchanges, insurers, insurance intermediaries and mutual societies. It is a central administrative authority with the mandate to promote stability and efficiency in the financial system as well as to ensure effective consumer protection.

\section{FI is accountable to the Ministry of Finance (MoF) and its annual budgets} are funded by the MoF. FI is a governed by an eight-member Board of Directors appointed by the government. The Director-General (DG) is the head of FI. The Swedish parliament is the only public body with the authority to adopt new laws or to amend existing legislation. The specific act authorizes the government to issue further regulations in an ordinance. The government is responsible for formulating and issuing financial sector legislations and regulations and may authorize FI to issue secondary regulations, only if it is specifically provided for under the relevant law or primary regulations.

22. FI supervises only private insurance business and social insurances are not subject to FI supervision. Social insurance is an integral part of the Swedish social security system, providing financial protection for disability, work injury, illness, and old age (state pension). Försäkringskassan is the agency that administers social insurance. While FI supervises the activities of life insurers in respect of occupational and private pension products, it collaborates closely with Pensionsmyndigheten, which administers the public pension segment.

\section{To enhance collaboration amongst regulatory/supervisory authorities in} Sweden, the MoF, the Riksbank, FI and the Swedish National Debt Office (SNDO) have signed a Memorandum of Understanding (MoU). The objective is to establish guidelines for consultation and the exchange of information between the parties in the

\footnotetext{
16 "The average guaranteed interest rate in the companies' portfolios is currently around 3.5 percent. Many agreements are 15-20 years old and promise a guaranteed interest rate of 5 percent, while new policies normally have a rate of between 2 percent and 2.5 percent."

17 "Risk in Financial System"-October 2010, FI and "How life insurance companies can affect financial stability”-Financial Stability Report 2/2010, Riksbank. ICP 20 below outlines FI's proposal to use interest smoothing rate under the impending Solvency II regime.
} 
areas of financial stability and crisis management. The MoU also provides for cooperation between the Riksbank and FI and their respective accountabilities. Pursuant to the MoU, a Domestic Standing Group ${ }^{18}$ was established to facilitate consultation and information sharing.

24. The key legislation governing private insurance activity in Sweden is the IBA and the Foreign Insurance Business Act (FIBA). IBA and FIBA set out the regulatory requirements for the establishment of insurance entities, rules pertaining to their operations and the supervisory mandate of FI. The IBA is supported by implementing regulations and guidelines that elaborates FI's supervisory expectations. The Insurance Contracts Act (ICA), which entered into force on 1 January 2006, regulates the legal relationship between insurers and insureds as well as other legitimate claimants. In general, any insurance clauses less favorable for consumers than those set forth in the ICA are invalid. A separate Motor Insurance Act applies to mandatory motor third party insurance.

\section{The authorities are taking proactive measures to address the key lessons} learnt from the financial crisis in 2008/9. Sweden has set up a government commission to review the lessons from the current crisis, including supervisory capacity building. ${ }^{19}$ In particular, the crisis highlighted that greater clarity is required on the respective roles of the various agencies for financial stability and the supervisory tools that they are empowered to use. ${ }^{20}$

\section{Key Findings and Recommendations}

26. The Swedish regulatory framework has a high level of observance with the ICPs (Table 7). The regulatory regime is broadly in line with EU Directives governing licensing, solvency, insurance intermediaries and consumer protection. FI has also introduced the Traffic-Light model, a framework for stress testing, to better understand insurers' risk exposures and facilitate early intervention. FI adopts a systematic supervisory risk assessment process to prioritizing and planning supervisory activities and resources. The new IBA, which came into effect on 1 April 2011, provides broader powers to FI to issue secondary regulations to address a number of supervisory gaps. The impending implementation of Solvency II will strengthen FI's risk-based supervision, subject to the adequacy of supervisory resources.

\section{The coverage and robustness of FI's prudential supervision should be} strengthened. FI has no legal authority to establish and assess fitness and propriety of

\footnotetext{
${ }^{18}$ The Group comprises the State Secretary (MoF), an executive board member of the Riksbank, the Director General of FI; and the Director General of the SNDO.

${ }^{19}$ The review covers: the division of labor on micro and macroprudential regulations among the relevant authorities; macroprudential tools; bank resolution framework and deposit insurance scheme; international reserve management; and supervisory capacity building.

${ }^{20}$ Riksbank's announcement: http://www.riksbank.com/templates/Page.aspx?id=43389.
} 
senior management of insurers during the licensing stage and on on-going basis. There is no regulatory requirement for insurers to report their reinsurance strategies and programs, outsourcing arrangements and off-balance sheet exposures including derivatives transactions. Supervision of insurance groups needs to be strengthened in the areas of reinsurance, risk concentrations and group risk management. FI has been focusing its supervision on the top 12 to 13 insurers while smaller insurers are inspected on an exception basis. Notably, FI has started a process to cover the smaller insurers on a 5-year cycle. It is advisable that FI formulates a risk-based supervision approach based on both the impact and probability of failure, supported by appropriate baseline supervision.

28. There is scope for additional regulatory requirement to enhance protection of policyholders. FI has not issued regulations or guidelines on conditional bonuses ${ }^{21}$ setting out how life insurers are expected to exercise their discretion in the distribution of surplus in an equitable manner, the basis for computing technical provisions and related disclosures to policyholders. The possibility of transferring policies by policyholders has increased in recent years, primarily due to the introduction of a mandatory option of transferring in 2007 and voluntary transfer of policies with regard to private collective insurances. It is recognized that most transfers of traditional policies are likely to result in lower benefits to policyholders due to the reduced assumed yield rates over the years. While the reduced benefits may be compensated by lower administration costs and products that are more suitable to the risk profiles of policyholders in some cases, it is timely to study the net impact on policyholders to ensure that their interests are not compromised. The authorities are advised to review whether existing regulatory measures are adequate to ensure that policyholders are given proper advice in their best interests in respect of policy transfers.

\section{The authorities are advised to review the continued involvement of the} government in institution-specific supervisory issues. The IBA explicitly provides for government's involvement in institution-specific issues such as license approval or revocation, issuing reprimands or imposition of administrative fines, or where an insurer fails to comply with an order by FI. While such involvement is intended for "matters of principle or special importance," the IBA does not specify the circumstances. The authorities explained that the government does not get involved as a matter of practice. Nonetheless, the possibility of intervention may compromise FI's independence.

30. It is important that FI is adequately resourced and empowered in order to effectively discharge its supervisory mandates. FI's insurance supervisory staffs are competent and qualified. However, due to inadequate resources to supervise a large number of insurers, FI had to make difficult compromises and has been unable to

${ }^{21}$ Some life policies provide for conditional bonuses that are not guaranteed but would vary according to the investment performance of the underlying assets. 
implement appropriate baseline supervision. Going forward, there are also significant resource implications arising from the implementation of Solvency II and supervision of cross-border insurance groups/conglomerates. The FI had a narrow scope in issuing binding secondary regulations to address emerging supervisory issues on timely basis. In this regard, the new IBA which provides FI with a broader mandate to issue secondary regulations is a positive development. The authorities are advised to carefully consider whether the level of legal protection available to the FI and its staff is at the level envisaged by ICP3.

Table 7. Sweden: Summary of Compliance with the ICPs

\begin{tabular}{|c|c|c|}
\hline ICP & Grading & Comments \\
\hline $\begin{array}{l}\text { 1. Conditions for effective } \\
\text { insurance supervision }\end{array}$ & $\mathrm{O}$ & $\begin{array}{l}\text { A sound and clearly defined financial sector policy framework } \\
\text { facilitates insurance supervision in Sweden. Swedish } \\
\text { accounting, auditing and actuarial standards are generally } \\
\text { consistent with international standards. There is a high degree } \\
\text { of self-regulation by the Swedish insurance industry. A well } \\
\text { developed financial infrastructure and easy access to } \\
\text { international markets contribute to the effectiveness of } \\
\text { insurers' asset-liability management. }\end{array}$ \\
\hline 2. Supervisory objectives & $\mathrm{O}$ & $\begin{array}{l}\text { FI's mandate is to promote a stable and well-functioning } \\
\text { financial system with a good level of consumer protection. }\end{array}$ \\
\hline 3. Supervisory authority & PO & $\begin{array}{l}\text { FI exercises supervision within the state budget framework and } \\
\text { MoF's annual appropriation letters and is subject to clear } \\
\text { accountability mechanisms. While FI's staff members are } \\
\text { competent and qualified, more supervisory resources are } \\
\text { required to implement a robust risk-based supervision, } \\
\text { supported by appropriate baseline supervision. FI had } \\
\text { experienced insufficient powers to issue secondary regulations } \\
\text { secondary regulations in a few concrete areas, a concern that } \\
\text { has been largely addressed by the new IBA. It is unclear } \\
\text { whether the legal protection available to FI and its staff is at the } \\
\text { level envisaged by ICP } 3 \text {. The possibility of government } \\
\text { involvement in institution-specific issues may compromise FI's } \\
\text { independence. }\end{array}$ \\
\hline 4. Supervisory process & $\mathrm{O}$ & $\begin{array}{l}\text { FI adopts a transparent supervisory approach, supported by the } \\
\text { Traffic Light model. It has instituted structured processes for } \\
\text { prioritization of supervisory activities and risk assessment to } \\
\text { ensure consistency in supervisory measures and decisions. FI } \\
\text { has clear accountabilities to the parliament, the industry and the } \\
\text { public through various channels. }\end{array}$ \\
\hline $\begin{array}{l}\text { 5. Supervisory cooperation } \\
\text { and information sharing }\end{array}$ & $\overline{\mathrm{O}}$ & $\begin{array}{l}\text { FI is empowered and regularly exchanges information with } \\
\text { other supervisors, both within and beyond EU, subject to } \\
\text { confidentiality safeguards. Sweden is a signatory of the } \\
\text { Helsinki protocol, the revised Siena protocol and Budapest } \\
\text { protocol. }\end{array}$ \\
\hline 6. Licensing & LO & $\begin{array}{l}\text { The licensing policy, criteria, and procedures are clear and } \\
\text { transparent. However, the IBA provides for government } \\
\text { involvement in the licensing of specific institutions. Senior }\end{array}$ \\
\hline
\end{tabular}




\begin{tabular}{|c|c|c|}
\hline ICP & Grading & Comments \\
\hline & & $\begin{array}{l}\text { managers (except Managing Director (MD)) are not subject to } \\
\text { fit and proper assessment. }\end{array}$ \\
\hline 7. Suitability of persons & LO & $\begin{array}{l}\text { FI conducts due diligence checks on board members, MDs as } \\
\text { well as qualifying holders of insurers and may remove such } \\
\text { persons if they are no longer fit and proper. FI has no power to } \\
\text { remove auditors or actuaries, nor do they have to be approved. } \\
\text { FI is also not empowered to assess senior managers (who are } \\
\text { not MD). FI may, however, take action indirectly by requiring } \\
\text { insurers to take corrective action if it finds that such persons do } \\
\text { not meet regulatory requirements. }\end{array}$ \\
\hline $\begin{array}{l}\text { 8. Changes in control and } \\
\text { portfolio transfers }\end{array}$ & $\mathrm{O}$ & $\begin{array}{l}\text { The regulatory requirements for acquisition and changes in } \\
\text { control as well portfolio transfer are clearly set out under the } \\
\text { IBA and FIBA. FI will not approve a portfolio transfer unless it } \\
\text { is satisfied that the rights of the policyholders would not be } \\
\text { adversely affected. }\end{array}$ \\
\hline 9. Corporate governance & $\mathrm{LO}$ & $\begin{array}{l}\text { The corporate governance framework for insurers is broadly in } \\
\text { line with ICP 9. FI examines insurers' corporate governance } \\
\text { practices during its on-site inspections and has taken necessary } \\
\text { supervisory measures, where appropriate. The authorities are } \\
\text { advised to strengthen the corporate governance regime for } \\
\text { insurers to reflect international standards and promote the } \\
\text { objectivity and effectiveness of the board of directors. }\end{array}$ \\
\hline 10. Internal controls & $\mathrm{O}$ & $\begin{array}{l}\text { FI supervises and assesses insurers' internal controls in line } \\
\text { with the requirements under the IBA and its corporate } \\
\text { governance guidelines. It is empowered and has taken } \\
\text { supervisory measures against insurers for deficiencies in } \\
\text { internal controls. }\end{array}$ \\
\hline 11. Market analysis & $\mathrm{LO}$ & $\begin{array}{l}\text { FI has a systematic and transparent approach to market analysis } \\
\text { to identify, assess and mitigate risks to the insurance sector. } \\
\text { The publication of insurance and other market statistics } \\
\text { facilitate insurers' understanding of systemic developments } \\
\text { that have implications for their operations. Due to limited } \\
\text { resources, FI does not analyze developments outside the } \\
\text { Swedish market on a regular basis. It would perform such } \\
\text { analysis, when found important, as part of its group } \\
\text { supervision. }\end{array}$ \\
\hline $\begin{array}{l}\text { 12. Reporting to } \\
\text { supervisors }\end{array}$ & $\mathrm{LO}$ & $\begin{array}{l}\text { FI has issued regulations and guidelines setting out the scope, } \\
\text { content and frequency of reports by different types of insurers. } \\
\text { It is also empowered to require additional reports necessary for } \\
\text { effective supervision or timely intervention. As the regulatory } \\
\text { returns are not audited, FI has to reconcile the returns with } \\
\text { insurers' audited annual reports. Insurers are not required to } \\
\text { report outsourcing arrangements as well as derivatives and off- } \\
\text { balance sheet transaction to FI regularly. FI does not have } \\
\text { adequate resources to conduct adequate off-site monitoring for } \\
\text { all licensed insurers. }\end{array}$ \\
\hline 13. On-site inspection & $\mathrm{LO}$ & $\begin{array}{l}\text { FI conducts both full scale and focused inspections. It has also } \\
\text { conducted joint inspections with foreign supervisors. It does }\end{array}$ \\
\hline
\end{tabular}




\begin{tabular}{|c|c|c|}
\hline ICP & Grading & Comments \\
\hline & & $\begin{array}{l}\text { not have adequate resources to implement baseline supervision } \\
\text { for a large number of supervised insurers and intermediaries, as } \\
\text { part of its risk-based supervision. Effective inspection should } \\
\text { go beyond a checklist approach in order to better understand } \\
\text { insurers' operations and risks. }\end{array}$ \\
\hline $\begin{array}{l}\text { 14. Preventive and } \\
\text { corrective measures }\end{array}$ & $\mathrm{O}$ & $\begin{array}{l}\text { FI is empowered to take a progressive escalation of preventive } \\
\text { measures to address emerging supervisory concerns. }\end{array}$ \\
\hline $\begin{array}{l}\text { 15. Enforcement or } \\
\text { sanction }\end{array}$ & $\mathrm{LO}$ & $\begin{array}{l}\text { FI takes a proportionate approach in exercising its enforcement } \\
\text { and sanction powers. However, FI has no power to: a) order a } \\
\text { compulsory transfer of insurance portfolios; b) intervene } \\
\text { against a subsidiary of an insurer who is not under its } \\
\text { supervision; and c) take measures to protect the interests of the } \\
\text { public and policyholders pending the completion of police } \\
\text { investigations. }\end{array}$ \\
\hline $\begin{array}{l}\text { 16. Winding-up or exit } \\
\text { from the market }\end{array}$ & $\mathrm{LO}$ & $\begin{array}{l}\text { The IBA and FIBA provides for orderly exits of insurers from } \\
\text { the market. Policyholders (including ceding insurers) and } \\
\text { legitimate beneficiaries have priority rights to the assets } \\
\text { covering insurers' technical provisions in the event of } \\
\text { insolvency. Regulatory requirements over assets covering } \\
\text { technical provisions could be strengthened and clear rules of } \\
\text { distribution of assets in the event of insolvency should be } \\
\text { established. }\end{array}$ \\
\hline $\begin{array}{l}\text { 17. Group-wide } \\
\text { supervision }\end{array}$ & LO & $\begin{array}{l}\text { Sweden's regulatory frameworks for insurance groups and } \\
\text { conglomerates are in line with current EU Directives. } \\
\text { However, there are no specific provisions regarding: } \\
\text { reinsurance, risk concentrations, internal controls and risk } \\
\text { management processes applicable to insurance groups The } \\
\text { impending implementation of Solvency II will strengthen } \\
\text { supervision of insurance groups, subject to the adequacy of } \\
\text { regulatory resources. }\end{array}$ \\
\hline $\begin{array}{l}\text { 18. Risk assessment and } \\
\text { management }\end{array}$ & $\mathrm{LO}$ & $\begin{array}{l}\text { FI has issued guidelines on its supervisory expectation of } \\
\text { insurers' risk management. There is a lack of resources to } \\
\text { implement policies and processes to monitor the adequacy of } \\
\text { insurers' risk management systems on a regular basis. }\end{array}$ \\
\hline 19. Insurance activity & LO & $\begin{array}{l}\text { FI has issued guidelines on managing underwriting risks and } \\
\text { reinsurance risks. It reviews insurers' underwriting policies and } \\
\text { controls as well as reinsurance arrangements during on-site } \\
\text { inspections. Supervisory processes in relation to assessment of } \\
\text { insurers' reinsurance arrangements and risk transfer } \\
\text { instruments could be enhanced. }\end{array}$ \\
\hline 20. Liabilities & $\mathrm{LO}$ & $\begin{array}{l}\text { FI has established principles and regulatory guidelines on the } \\
\text { computation of insurers' technical provisions, which are } \\
\text { subject to stress testing under the Traffic Light Model. FI is } \\
\text { empowered to require insurers to remedy any shortfall in their } \\
\text { technical provisions, if necessary. However, there is no explicit } \\
\text { risk margin and no regulatory policy for computing technical } \\
\text { provisions in respect of conditional bonuses. }\end{array}$ \\
\hline
\end{tabular}




\begin{tabular}{|c|c|c|}
\hline ICP & Grading & Comments \\
\hline 21. Investments & LO & $\begin{array}{l}\text { The IBA and FI regulations set out the requirements for } \\
\text { insurers' investments covering technical provisions. There is } \\
\text { scope for updating FI's regulations to reflect international best } \\
\text { practice. FI does not have adequate resources to examine } \\
\text { insurers' investment operations on a regular basis. }\end{array}$ \\
\hline $\begin{array}{l}\text { 22. Derivatives and similar } \\
\text { commitments }\end{array}$ & $\mathrm{PO}$ & $\begin{array}{l}\text { Insurers disclose their derivative activities in accordance with } \\
\text { relevant accounting standards, Annual Reports Act (ARA) and } \\
\text { Annual Reports for Insurance Undertakings Act (ARIUA). } \\
\text { However, FI has not issued regulations on insurers' derivative } \\
\text { activities. It is in the process of drafting the regulations; as it is } \\
\text { authorized do so under the new IBA. }\end{array}$ \\
\hline $\begin{array}{l}\text { 23. Capital adequacy and } \\
\text { solvency }\end{array}$ & LO & $\begin{array}{l}\text { The current solvency regime in Sweden is largely based on EU } \\
\text { Solvency I. As the regime does not take account of all key risks } \\
\text { of insurers, FI has introduced the Traffic Light model with } \\
\text { prescribed stress testing and reporting requirements as a } \\
\text { supervisory tool to better understand insurers' risks profiles } \\
\text { and to facilitate early intervention, where appropriate. }\end{array}$ \\
\hline 24. Intermediaries & $\mathrm{O}$ & $\begin{array}{l}\text { FI administers the licensing of intermediaries with established } \\
\text { criteria and monitors intermediaries' compliance with } \\
\text { applicable regulatory requirements. }\end{array}$ \\
\hline 25. Consumer Protection & LO & $\begin{array}{l}\text { The regime for consumer protection in Sweden is established } \\
\text { under various legislations, administered mainly by FI and } \\
\text { Swedish Consumer Agency (SCA) with the support of industry } \\
\text { associations. Other agencies involved include the National } \\
\text { Board for Consumer Complaints and the Consumer } \\
\text { Ombudsman. Consumer protection should be strengthened by } \\
\text { establishing regulatory requirements for conditional bonuses } \\
\text { and review of effectiveness of regulatory measures for transfer } \\
\text { of policies. }\end{array}$ \\
\hline $\begin{array}{l}\text { 26. Information, disclosure } \\
\text { and transparency towards } \\
\text { markets }\end{array}$ & LO & $\begin{array}{l}\text { The ARIUA, ARA as well as regulations and guidelines issued } \\
\text { by FI governs insurers' public disclosure. However, the } \\
\text { disclosures do not fully cover the requirements under the IAIS } \\
\text { standards on public disclosure. }\end{array}$ \\
\hline 27. Fraud & $\mathrm{O}$ & $\begin{array}{l}\text { FI and industry participants have taken a proactive approach to } \\
\text { combating insurance fraud. There is also close cooperation and } \\
\text { information exchange with Swedish Economic Crime } \\
\text { Authority (SECA) and other enforcement agencies and other } \\
\text { supervisors, both locally and internationally, to address fraud to } \\
\text { preserve the integrity of the insurance sector. }\end{array}$ \\
\hline $\begin{array}{l}\text { 28. Anti-money- } \\
\text { laundering, combating the } \\
\text { financing of terrorism }\end{array}$ & LO & $\begin{array}{l}\text { Recent FATF follow-up report has noted that Sweden has } \\
\text { taken measures to bring } 18 \text { out of the } 20 \text { recommendations } \\
\text { previously rated partially compliant or noncompliant to at least } \\
\text { a level equivalent to largely compliant. More supervisory } \\
\text { resources are needed to ensure effective supervision of anti- } \\
\text { money laundering/combating the financing of terrorism (AML- } \\
\text { CFT) compliance by insurers' and insurance intermediaries. }\end{array}$ \\
\hline
\end{tabular}


Summary of Grading

\begin{tabular}{|l|c|}
\hline Observed (O) & 9 \\
\hline Largely observed (LO) & 17 \\
\hline Partly observed (PO) & 2 \\
\hline Not Observed (NO) & 0 \\
\hline Total & 28 \\
\hline
\end{tabular}

Table 8. Sweden: Recommendations to Improve Observance of ICPs

\begin{tabular}{|c|c|}
\hline ICP & Comments \\
\hline 2. Supervisory objectives & $\begin{array}{l}\text { The authorities are advised to consider adopting explicit supervisory } \\
\text { objectives for the insurance sector, including FI's role in protecting } \\
\text { policyholders. }\end{array}$ \\
\hline 3. Supervisory authority & $\begin{array}{l}\text { The authorities are advised to: } \\
\text { a) Review the adequacy of supervisory resources for effective } \\
\text { implementation of a more robust risk-based supervision; } \\
\text { b) Consider a more principle-based approach in respect of the scope for } \\
\text { FI to issue secondary regulations; } \\
\text { c) Review the role of the government in institution-specific supervisory } \\
\text { issues; } \\
\text { d) Consider reviewing whether the legal protection available to FI and its } \\
\text { staff members are at the level envisaged by ICP3; and } \\
\text { e) Require publication of the reasons for the removal of board members } \\
\text { and the DG of FI. }\end{array}$ \\
\hline 4. Supervisory process & $\begin{array}{l}\text { The authorities are advised to consider reviewing the impact of judicial } \\
\text { review on the ability of FI to make timely interventions to protect } \\
\text { policyholders' interests. }\end{array}$ \\
\hline $\begin{array}{l}\text { 5. Supervisory cooperation } \\
\text { and information sharing }\end{array}$ & $\begin{array}{l}\text { The authorities are advised to expedite Sweden's accession to the IAIS } \\
\text { multilateral MoU. }\end{array}$ \\
\hline 6. Licensing & $\begin{array}{l}\text { The authorities are advised to: } \\
\text { a) review the government's role in the licensing process under the IBA; } \\
\text { b) extend the fit and proper assessment to senior management of } \\
\text { insurers; } \\
\text { c) consider empowering FI to impose licensing conditions; and } \\
\text { d) consider having a definition of insurance business in the IBA. }\end{array}$ \\
\hline 7. Suitability of persons & $\begin{array}{l}\text { The authorities should introduce regulations including: } \\
\text { a) explicit provision for FI to assess the fitness and propriety of senior } \\
\text { management of insurers as well as their auditors and actuaries; and } \\
\text { b) to require insurers to notify FI of circumstances that may affect the } \\
\text { fitness and propriety of its board members, MD, senior managers, } \\
\text { auditors and actuaries. }\end{array}$ \\
\hline 9. Corporate governance & The authorities are advised to establish clear corporate governance \\
\hline
\end{tabular}




\begin{tabular}{|c|c|}
\hline ICP & Comments \\
\hline & $\begin{array}{l}\text { standards for insurers on: } \\
\text { a) The minimum level of independent directors and criteria for } \\
\text { independence; } \\
\text { b) Establishment of relevant board committees, taking into account the } \\
\text { nature, scale and complexity of their operations; } \\
\text { c) Policies and procedures to assess the effectiveness of their boards; } \\
\text { d) The role and accountabilities of senior managers; and } \\
\text { a) Providing actuaries with direct access to the board and board } \\
\text { committee on a timely basis. }\end{array}$ \\
\hline 10. Internal controls & $\begin{array}{l}\text { To strengthen the checks and balances of insurers' operations, FI is } \\
\text { advised to consider adopting explicit provisions to ensure that internal } \\
\text { auditors have unfettered access to the board and senior management as } \\
\text { well as appropriate status to ensure that senior management acts upon its } \\
\text { recommendation. }\end{array}$ \\
\hline 11. Market analysis & $\begin{array}{l}\text { It is important that FI enhance its capacity and resources to analyze the } \\
\text { developments outside the Swedish market on a regular basis including } \\
\text { Swedish insurers' exposures to foreign risks. }\end{array}$ \\
\hline 12. Reporting to supervisors & $\begin{array}{l}\text { FI is advised to: } \\
\text { a) formulate a more robust risk-based supervision approach based on } \\
\text { both the impact and probability of failure, supported by an appropriate } \\
\text { baseline supervision; } \\
\text { b) review the adequacy of resources for off-site monitoring; } \\
\text { c) establish clear regulatory requirement for insurers to report their } \\
\text { reinsurance strategy and program, outsourcing arrangements and off- } \\
\text { balance sheet exposures including derivatives transactions; and } \\
\text { d) require annual regulatory returns of insurers to be audited. }\end{array}$ \\
\hline 13. On-site inspection & $\begin{array}{l}\text { FI is advised to improve the robustness of on-site inspection and ensure } \\
\text { that the planned baseline onsite supervisory program is supported by } \\
\text { adequate supervisory resources. }\end{array}$ \\
\hline 15. Enforcement or sanction & $\begin{array}{l}\text { The authorities are advised to: } \\
\text { a) Empower FI to order a c; } \\
\text { b) ompulsory transfer of insurance portfolios of an insurer in distress; } \\
\text { c) Strengthen FI's intervention powers against unregulated entities } \\
\text { within an insurance group or financial conglomerate; } \\
\text { d) Consider how best to empower FI in taking necessary measures to } \\
\text { protect the interests of the public pending the completion of police } \\
\text { investigations; and } \\
\text { e) Review the government's continued involvement in enforcement and } \\
\text { sanctions at institution-specific level. }\end{array}$ \\
\hline $\begin{array}{l}\text { 16. Winding-up or exit from } \\
\text { the market }\end{array}$ & $\begin{array}{l}\text { The authorities are advised to strengthen protection of policyholders and } \\
\text { legitimate beneficiaries by: } \\
\text { a) ensuring adequate controls over assets covering technical provisions }\end{array}$ \\
\hline
\end{tabular}




\begin{tabular}{|c|c|}
\hline ICP & Comments \\
\hline & $\begin{array}{l}\text { including quarterly submission of the special register of assets; and } \\
\text { b) establishing clear rules on how existing assets of an insolvent insurer } \\
\text { are to be distributed amongst policyholders. }\end{array}$ \\
\hline 17. Group-wide supervision & $\begin{array}{l}\text { The authorities are advised to consider: } \\
\text { a) reviewing the adequacy of supervisory resources, particularly for the } \\
\text { effective supervision of cross-border groups/conglomerates; } \\
\text { b) harmonizing the supervisory approach for insurance groups and } \\
\text { conglomerates, e.g., in the area of risk concentration; and } \\
\text { c) formulating appropriate regulatory requirements applicable to } \\
\text { nonregulated holding companies. }\end{array}$ \\
\hline $\begin{array}{l}\text { 18. Risk assessment and } \\
\text { management }\end{array}$ & $\begin{array}{l}\text { FI is advised to develop policies and processes to monitor the adequacy of } \\
\text { insurers' risk management systems on a regular basis including requiring } \\
\text { insurers to report on their risk management system as part of the annual } \\
\text { returns. }\end{array}$ \\
\hline 19. Insurance activity & $\begin{array}{l}\text { FI is advised to: } \\
\text { a) review the adequacy of reinsurance programs as part of its routine off- } \\
\text { site surveillance instead of the current limited scope review; and } \\
\text { b) establish policies and procedures to check that insurers properly } \\
\text { account for all risk transfer instruments. }\end{array}$ \\
\hline 20. Liabilities & $\begin{array}{l}\text { The implementation of Solvency II will strengthen FI's supervision over } \\
\text { insurers' technical provisions. }\end{array}$ \\
\hline 21. Investments & $\begin{array}{l}\text { FI is advised to enhance the robustness of its supervision of insurers' } \\
\text { investment operations and update its regulations on investment } \\
\text { management by insurers. }\end{array}$ \\
\hline $\begin{array}{l}\text { 22. Derivatives and similar } \\
\text { commitments }\end{array}$ & $\begin{array}{l}\text { The authorities are advised to expedite the issuance of regulations } \\
\text { governing insurers' derivative activities. }\end{array}$ \\
\hline $\begin{array}{l}\text { 23. Capital adequacy and } \\
\text { solvency }\end{array}$ & $\begin{array}{l}\text { The implementation of Solvency II with effect from January } 2013 \text { will } \\
\text { facilitate FI in implementing a more robust and risk-sensitive solvency } \\
\text { regime. }\end{array}$ \\
\hline 25. Consumer protection & $\begin{array}{l}\text { The authorities are advised to: } \\
\text { a) review the adequacy of current regulatory requirements for } \\
\text { conditional bonus and transfer of policies; and } \\
\text { b) consider articulating more clearly the roles and accountabilities of } \\
\text { various agencies involved in consumer protection to improve } \\
\text { efficiency and promote better understanding by consumers. }\end{array}$ \\
\hline $\begin{array}{l}\text { 26. Information, disclosure } \\
\text { and transparency towards } \\
\text { markets }\end{array}$ & $\begin{array}{l}\text { To facilitate market discipline, FI should formulate plans to implement the } \\
\text { IAIS supervisory standards on public disclosures. }\end{array}$ \\
\hline $\begin{array}{l}\text { 28. Anti-money-laundering, } \\
\text { combating the financing of } \\
\text { terrorism }\end{array}$ & $\begin{array}{l}\text { The authorities are advised to: } \\
\text { a) review the adequacy of resources for AML-CFT supervision; and } \\
\text { b) update the legal requirements where insurers rely on intermediaries to } \\
\text { perform customer due diligence (CDD). }\end{array}$ \\
\hline
\end{tabular}




\section{Authorities' response to the assessment}

31. The Swedish authorities welcome the assessment of the regulation and supervision of the insurance sector. On the whole, we share the views expressed in the assessment as well as the grading of observance of the Insurance Core Principles. The recommendations given will be used to improve the regulation and supervision of the Swedish insurance sector.

32. Several of the issues raised will be dealt with once the new regulatory framework for the insurance sector, i.e. Solvency II, is implemented. Sweden is also participating in ongoing work carried out by IAIS on Internationally Active Insurance Groups, which will contribute to further development of the supervisory standard. Additionally, regulation regarding transfer of policies as well as other life insurance related issues is currently under national review. 


\section{Detailed Principle-by-Principle Assessment Methodology}

\section{Table 9. Sweden: Detailed Assessment}

\begin{tabular}{|c|c|}
\hline \multicolumn{2}{|c|}{ Conditions for Effective Insurance Supervision } \\
\hline Principle 1. & $\begin{array}{l}\text { Conditions for effective insurance supervision } \\
\text { Insurance supervision relies upon: } \\
\text { - a policy, institutional and legal framework for financial sector supervision; } \\
\text { - a well developed and effective financial market infrastructure; and } \\
\text { - efficient financial markets. }\end{array}$ \\
\hline Description & $\begin{array}{l}\text { The Financial Supervisory Authority Instructions Ordinance (FIO) establishes FI as the } \\
\text { integrated supervisor for the entire financial sector. FI is responsible for: a) the supervision, } \\
\text { rule establishment and processing of license applications relating to financial markets and } \\
\text { financial entities; and b) coordinating supervision under the Money Laundering and Terrorist } \\
\text { Financing Ordinance (MLTFO) (s1 of FIO). } \\
\text { The IBA sets out the legal and policy framework for the supervision of the insurance } \\
\text { industry, providing FI with a range of enforcement and sanction powers (see ICP } 14 \text { and } \\
\text { ICP 15). } \\
\text { In Sweden, the general courts handle criminal and civil cases, while the general } \\
\text { administrative courts deal with cases concerning public administration. Both types of courts } \\
\text { are organized in a three-tier system with courts of first instance, appeals courts and a supreme } \\
\text { court. } \\
\text { Proceedings concerning financial legislation and regulation are normally heard by the } \\
\text { administrative courts, e.g., when a firm appeals a decision made by FI. Permanent judges in } \\
\text { Sweden are appointed by the Government. Provisions in the Swedish Instrument of } \\
\text { Government (SIG), one of the four statutes that make up the Swedish constitution, address } \\
\text { the independence of judges and enumerate the grounds on which judges can be dismissed. } \\
\text { (SIG cpt11, s7). } \\
\text { The ARIUA is generally consistent with International Financial Reporting Standards (IFRS), } \\
\text { albeit with some local adaptation. The Swedish auditing standards are based upon the } \\
\text { International Standards on Auditing issued by International Auditing and Assurance } \\
\text { Standards Board. Actuarial standards are set out in IBA and guidelines issued by FI. (S10 of } \\
\text { FIO). } \\
\text { Auditors and actuaries must meet the requirements under the IBA. Only approved auditors }{ }^{1} \\
\text { or chartered accountants }{ }^{2} \text { may serve as auditors of insurers and they must be independent } \\
\text { from insurers. Insurers' estimation of technical provisions shall be performed under the }\end{array}$ \\
\hline
\end{tabular}

\footnotetext{
${ }^{1}$ An approved auditor ( $S w$. godkänd revisor) is authorised by the Swedish Supervisory Board of Public Accountants ( $S w$. Revisorsnämnden) for a period of five years. The qualifying criteria include: a university degree in economics; at least three years recognised practical experience; passed an examination of professional competence; and of good repute and otherwise be fit and proper.

${ }^{2}$ A chartered accountant ( $S w$. auktoriserad revisor) is also authorised by the Swedish Supervisory Board of Public Accountants for a period of five years. In addition to the standards set out above, a chartered accountant must have at least five years recognised practical experience and pass an advanced examination of professional competence.
} 


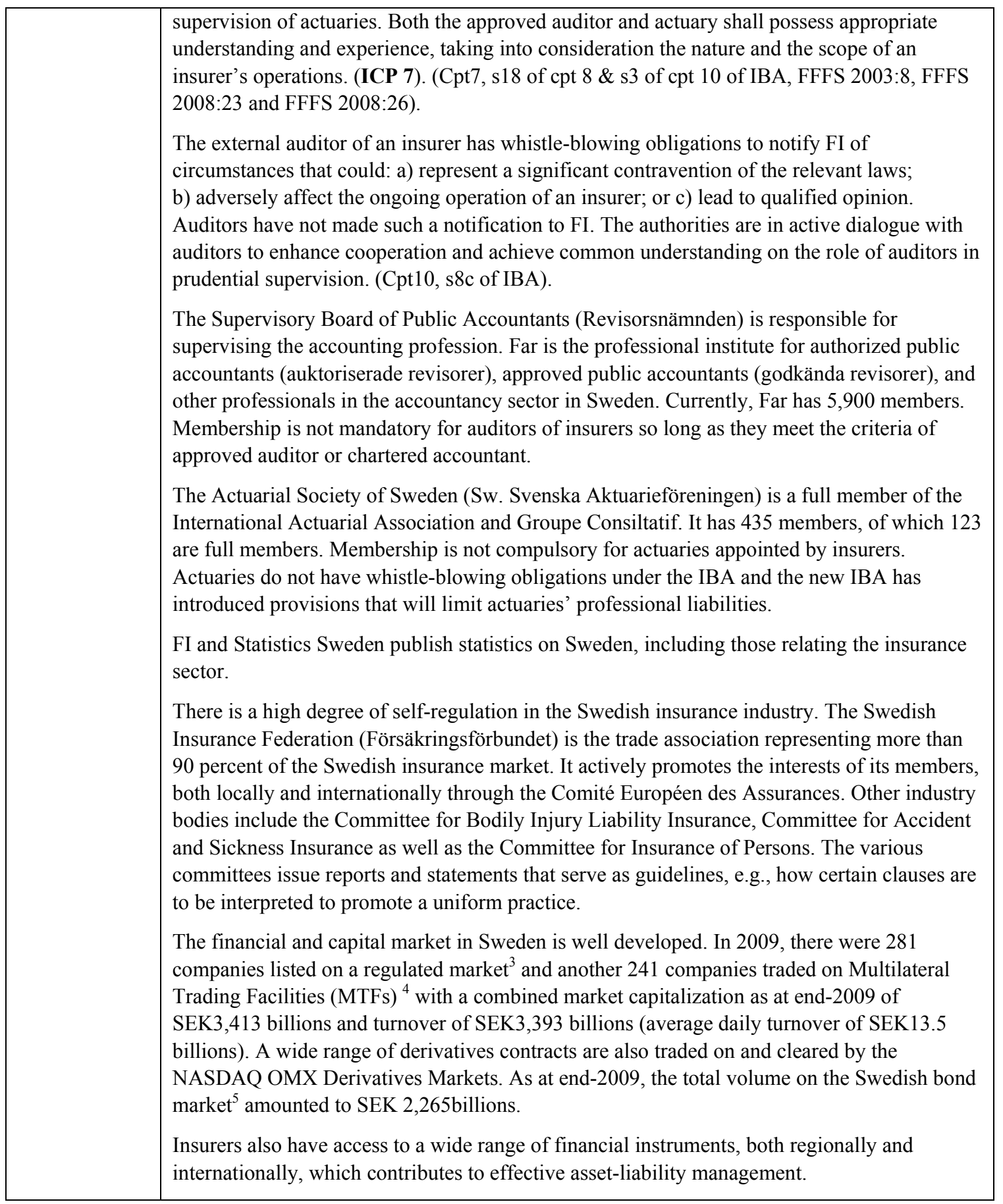

\footnotetext{
${ }^{3}$ There are two regulated markets in Sweden: NASDAQ OMX Stockholm and Nordic Growth Market.

${ }^{4}$ There were four MTFs in Sweden: First North, Nordic MTF, Burgundy and Aktietorget.

${ }^{5}$ The term Swedish bond market refers to the market for bonds issued by Swedish issuers in SEK. Bonds issued in other currencies are converted into SEK. As a rule, issuances conducted in other currencies are converted into SEK via derivatives, primarily currency swaps. Insurers were the largest category of investors in the SEK bond market, accounting for approximately 50 percent of the outstanding in the bond market as at end-2009.
} 


\begin{tabular}{|c|c|}
\hline & $\begin{array}{l}\text { Sweden updates its laws regularly in order to reflect changes in EU Directives and to keep } \\
\text { pace with international and market developments. }\end{array}$ \\
\hline Assessment & Observed \\
\hline Comments & $\begin{array}{l}\text { A sound and clearly defined financial sector policy framework facilitates insurance } \\
\text { supervision in Sweden. Swedish accounting, auditing and actuarial standards are generally } \\
\text { consistent with international standards. There is a high degree of self-regulation by the } \\
\text { Swedish insurance industry. A well-developed financial infrastructure and easy access to } \\
\text { international markets contribute to the effectiveness of insurers' asset-liability management. }\end{array}$ \\
\hline \multicolumn{2}{|c|}{ The Supervisory System } \\
\hline Principle 2. & $\begin{array}{l}\text { Supervisory objectives } \\
\text { The principal objectives of insurance supervision are clearly defined. }\end{array}$ \\
\hline Description & $\begin{array}{l}\text { FI has the mandate to promote a stable and well-functioning financial system with a good } \\
\text { level of consumer protection. It has a duty to notify the government of risks of financial } \\
\text { sector instability that may have a negative impact on the functioning of the Swedish } \\
\text { financial system. It cooperates with the Riksbank and the Swedish Civil Contingencies } \\
\text { Agency under the Crisis Management and Enhanced Preparedness Ordinance. (S2, s3, and } \\
\text { s6 of FIO). } \\
\text { FI's mandate for consumer protection is shared with the SCA, with the involvement of } \\
\text { other government agencies including the National Board for Consumer Complaints (ARN) } \\
\text { and the Consumer Ombudsman, who pursue individual consumers' cases. (See ICP 25). } \\
\text { While the supervisory objectives for the insurance sector are not explicitly stated in the } \\
\text { laws or regulations, FI issues various public reports describing and discussing different } \\
\text { issues concerning the financial system, where the objectives for supervision forms an } \\
\text { explicit background. The DG and senior staff of FI frequently take part in public seminars } \\
\text { and discussions on issues relevant to its mandate. } \\
\text { FI's vision is that: a) its efforts prevent financial crises from arising in the market; b) } \\
\text { companies and consumers have access to a broad selection of services with clear conditions } \\
\text { in an efficient and well-functioning financial market; and c) market participants view FI as } \\
\text { a highly competent authority that offers guidance. } \\
\text { FI has established an internal process to systematically survey and assess the need for } \\
\text { changes to its regulatory mandate. Every autumn, FI determines which areas will be } \\
\text { prioritized during the next year. In } 2009 \text {, FI prioritized the following areas: a) stability and } \\
\text { a functioning market; b) consumer protection and ; c) staff members - attractive employer; } \\
\text { and d) efficiency - good insight and competition. } \\
\text { FI has no responsibility for financial sector development, for which the MoF is primarily } \\
\text { resposnsible. There is a Financial Markets Committee with the objective to promote } \\
\text { development of the financial sector }{ }^{8} \text {. The Committee arranges the Financial Markets } \\
\text { Roundtable twice a year, attended by the Governor of the Riksbank, the DG of FI, the DG } \\
\text { of the National Debt Office and CEOs from major banks, Nasdaq OMX Nordic and }\end{array}$ \\
\hline
\end{tabular}

\footnotetext{
6 "Who we are and what we do" FI, 2009 (FI website).

${ }^{7}$ FI's strategic goal is to be the best in the Nordic countries and the Baltic Sea region in areas such as customer satisfaction, processing times and electronic reporting.

${ }^{8}$ See http://www.sou.gov.se/fmk/inenglish.htm.
} 


\begin{tabular}{|c|c|}
\hline & S \\
\hline Assessment & Observed \\
\hline Comments & $\begin{array}{l}\text { FI's mandate is to promote a stable and well-functioning financial system with a good level } \\
\text { of consumer protection. } \\
\text { The authorities are advised to consider adopting explicit supervisory objectives for the } \\
\text { insurance sector, including FI's role in protecting policyholders. }\end{array}$ \\
\hline Principle 3. & $\begin{array}{l}\text { Supervisory authority } \\
\text { The supervisory authority: } \\
\text { - has adequate powers, legal protection and financial resources to exercise its functions and } \\
\text { powers: } \\
\text { - is operationally independent and accountable in the exercise of its functions and powers; } \\
\text { - hires, trains and maintains sufficient staff with high professional standards; and } \\
\text { - treats confidential information appropriately. }\end{array}$ \\
\hline Description &  \\
\hline
\end{tabular}

\footnotetext{
${ }^{9}$ Essential criterion 3c) states: "The legislation grants sufficient powers for the effective discharge of supervisory responsibilities."
} 


\begin{tabular}{|c|}
\hline 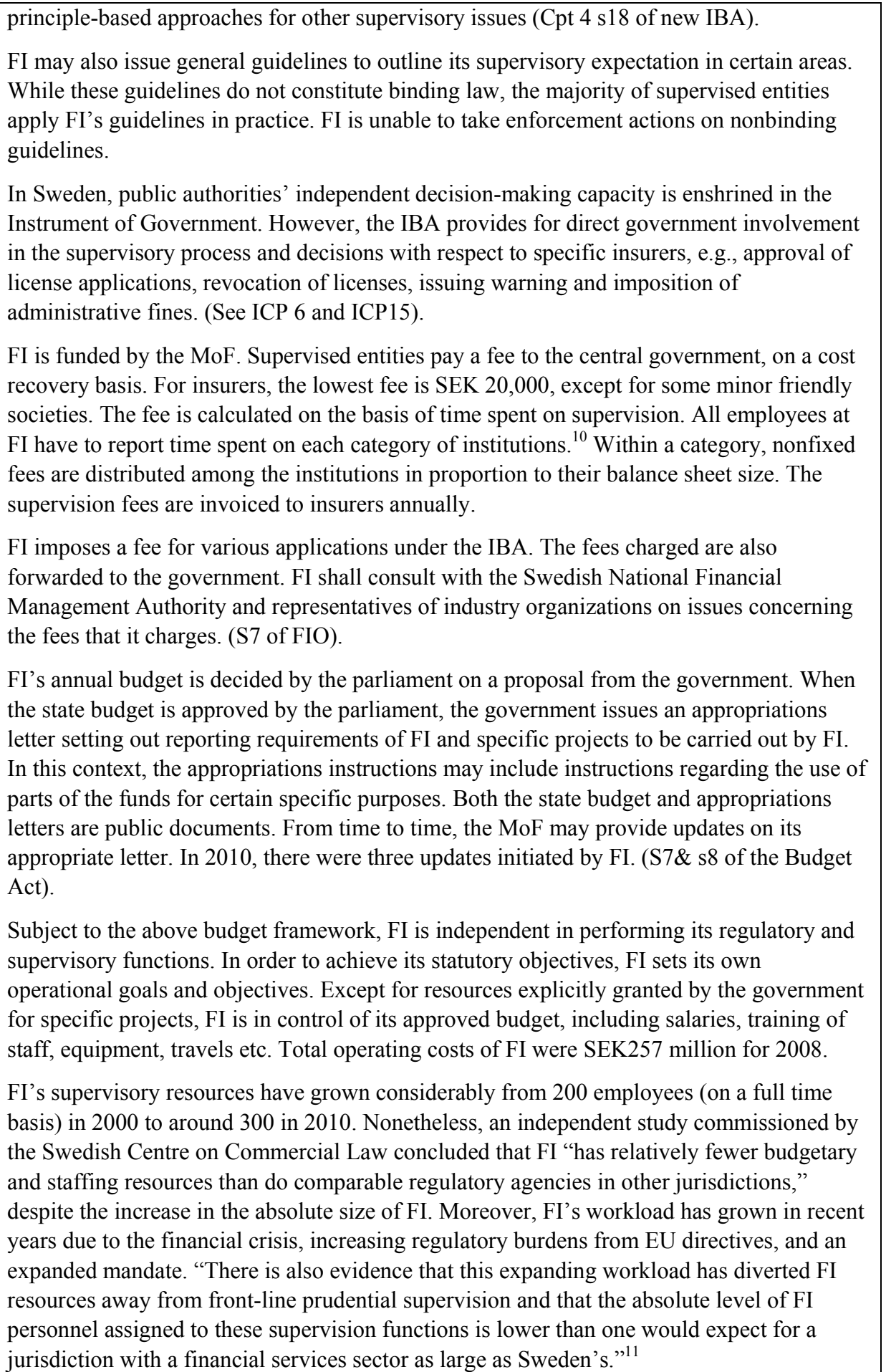 \\
\hline
\end{tabular}

${ }^{10}$ There are five major categories of institutions: 1) banks, savings banks and securities companies; 2) credit institutions; 3) Insurance undertakings, friendly societies; 4) stock exchanges, authorised marketplaces and clearing houses; and 5) Fund management companies.

${ }^{11}$ A Report on the Mandate, Structure and Resources of the Swedish Financial Supervisory Authority by Professor 


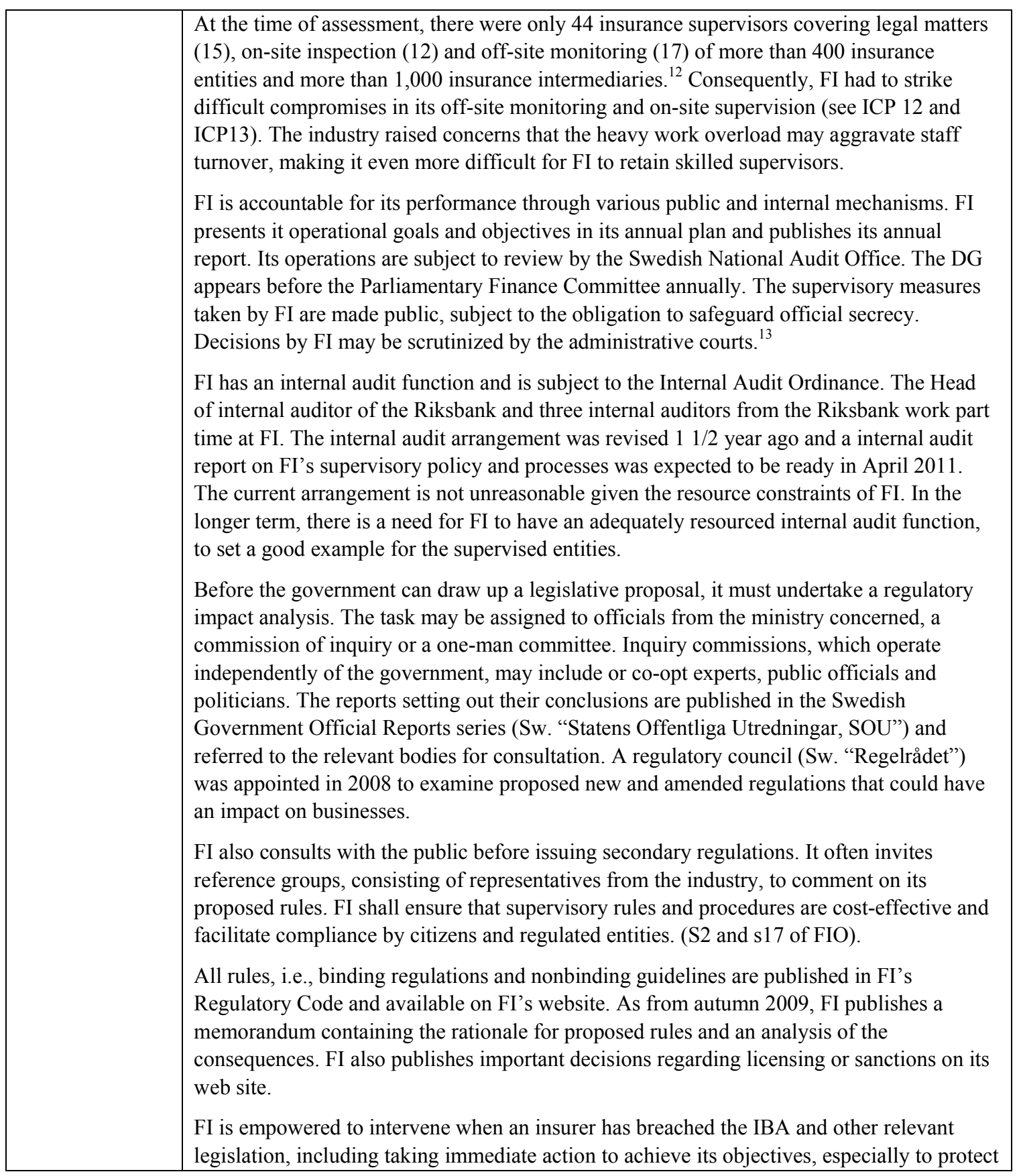

Howell E. Jackson James S. Reid, Jr., Professor of Law Harvard Law School.

${ }^{12}$ There is a separate unit with 6 staff responsible for assessing and approving internal models of supervised entities and intermediaries are supervised by a separate unit with 7 staff, who are also responsible for a large number of funds.

${ }^{13}$ For example, FI revoked NGM's license on 1 October 2009. The Stockholm County Administrative Court later ruled that NGM's license to operate a regulated market and trading facility would not be revoked. NGM was issued a warning instead and a financial penalty of SEK 4.5 million to the Government in accordance with FI's proposal. Source: "Who we are and what we do" FI, 2009. 


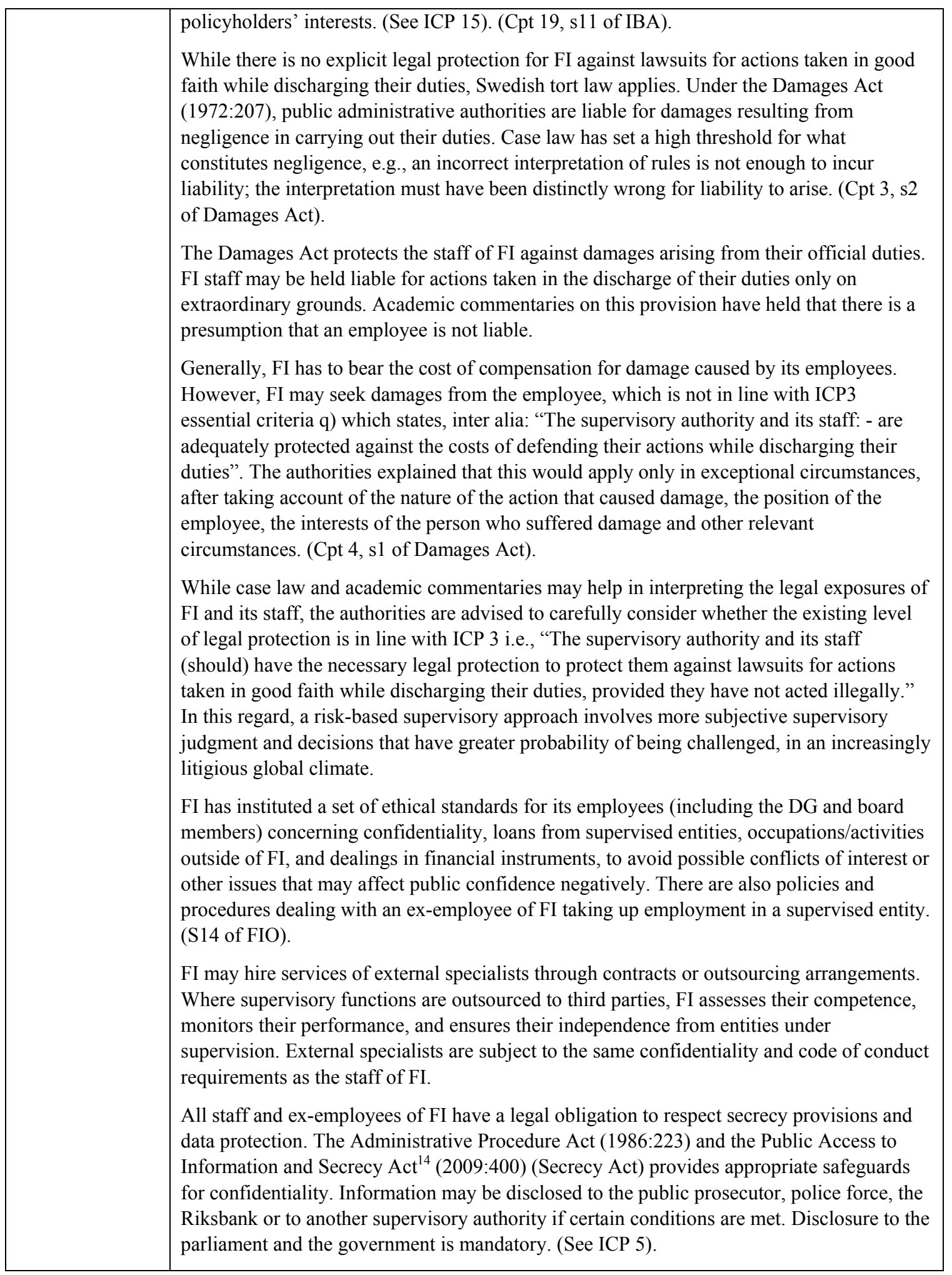

\footnotetext{
${ }^{14}$ General secrecy provisions regarding financial markets are set out in chapter 30 of the Public Access to
} Information and Secrecy Act. 


\begin{tabular}{|c|c|}
\hline & $\begin{array}{l}\text { Confidential information received from another competent authority in a country within the } \\
\text { European Economic Area (EEA) is protected by general secrecy provisions, without the } \\
\text { necessity of specific statutory provisions. }\end{array}$ \\
\hline Assessment & Partly Observed \\
\hline Comments & $\begin{array}{l}\text { FI exercises supervision within the state budget framework and MoF's annual appropriation } \\
\text { letters and is subject to clear accountability mechanisms. While FI's staff members are } \\
\text { competent and qualified, more supervisory resources are required to implement a robust } \\
\text { risk-based supervision, supported by appropriate baseline supervision. FI had experienced } \\
\text { insufficient powers to issue secondary regulations secondary regulations in a few concrete } \\
\text { areas, a concern that has been largely addressed by the new IBA. It is unclear whether the } \\
\text { legal protection available to FI and its staff is at the level envisaged by ICP 3. The } \\
\text { possibility of government involvement in institution-specific issues may compromise FI's } \\
\text { independence. } \\
\text { The authorities are advised to: } \\
\text { a) review the adequacy of supervisory resources for effective implementation of a more } \\
\text { b) consist risk-based supervision; } \\
\text { secondary regulations; } \\
\text { c) review the role of the government in institution-specific supervisory issues; } \\
\text { d) consider reviewing whether the legal protection available to FI and its staff members } \\
\text { are at the level envisaged by ICP3; and } \\
\text { e) require publication of the reasons for the removal of board members and the DG of FI. }\end{array}$ \\
\hline Principle 4. & $\begin{array}{l}\text { Supervisory process } \\
\text { The supervisory authority conducts its functions in a transparent and accountable manner. }\end{array}$ \\
\hline Description & $\begin{array}{l}\text { FI has issued an internal memorandum on "The process for carrying out operational } \\
\text { supervisory activities," which applies to both planned and ad-hoc supervisory activities. } \\
\text { The key objectives are to ensure continuous prioritization and planning of work, proper } \\
\text { checks and balance, quality assurance and proper documentation. } \\
\text { FI's supervisory activities are prioritized in relation to: other supervisory activities, FI's } \\
\text { goals and its risk assessment. Quality assurance is achieved through the use of an } \\
\text { "Observation Document," structured analysis of data/information to decide on the } \\
\text { supervisory options as well as formal closure of cases (by the head of unit or authorized } \\
\text { staff). Decisions to impose sanctions are made by the FI's board of directors. } \\
\text { For proper accountability and as part of the staff's learning process, a supervisory activity } \\
\text { is evaluated after completion. The evaluation is carried out by the staff team and approved } \\
\text { by the head of unit. } \\
\text { FI's Risk Assessment Process aims to produce a risk profile for use by each supervision } \\
\text { department and an aggregate risk profile for FI. The process prioritizes the risks in each } \\
\text { area and forms a starting point for discussion on planned supervisory activities and } \\
\text { resources. The risk areas are consumers, financial stability and their effects on } \\
\text { confidence/efficiency. An evaluation of whether a risk should be included in the risk } \\
\text { assessment is carried out on the basis of the likelihood of the unfavorable event occurring } \\
\text { and its impact. The aim is to create a tool for prioritization, not a risk profile according to a } \\
\text { scale. } \\
\text { The supervisory risk assessment covers only more specific risks. Risks of a general or }\end{array}$ \\
\hline
\end{tabular}




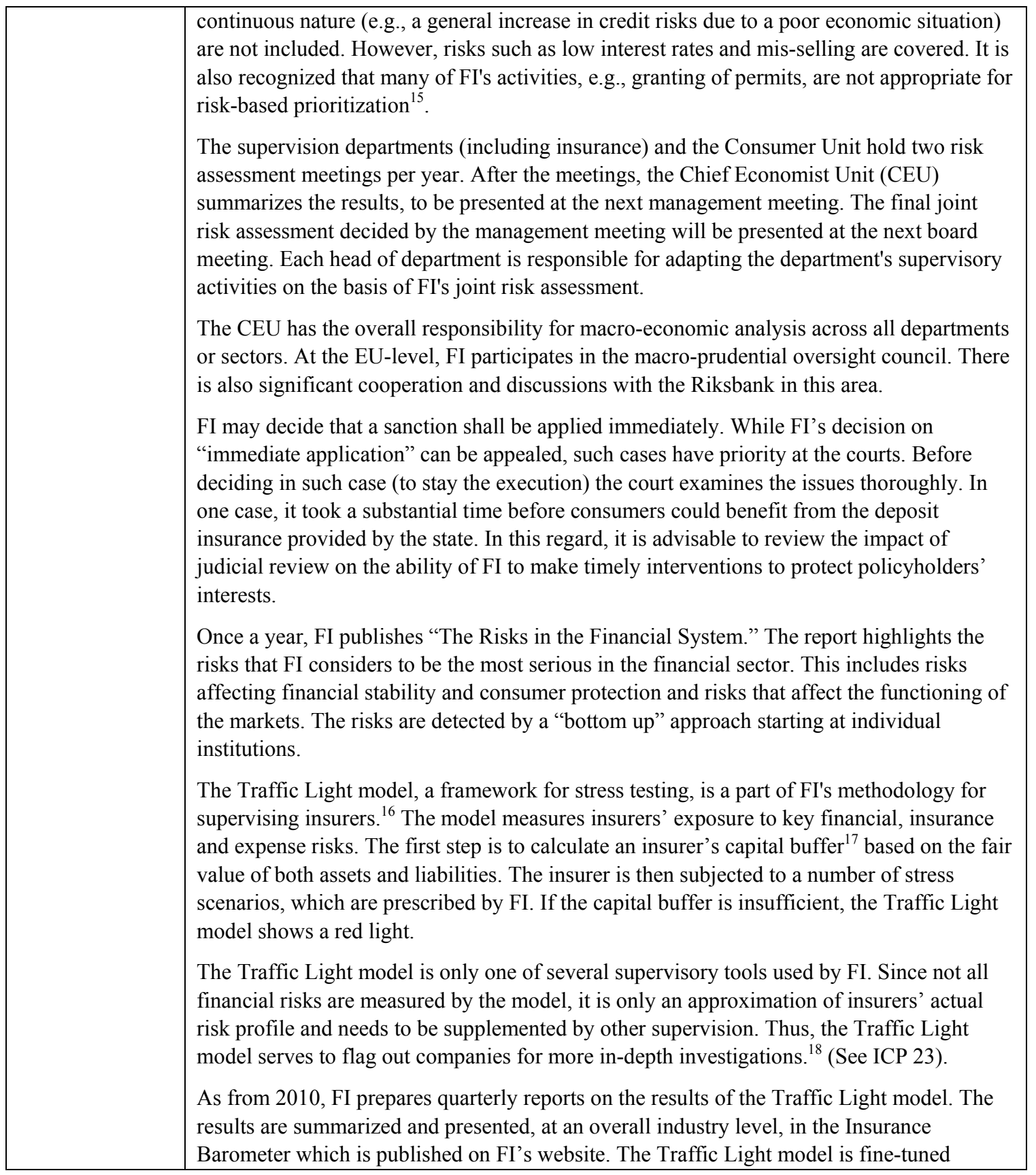

15 The Risk Assessment Process, dated 2011-1-27 by FI.

${ }^{16}$ FI started to develop and the traffic light model in 2005, taking account of the lessons learnt from the sharp decline in the stock market during the period 2000-2002, and the subsequent drop in interest rates that weakened insurers' financial strength.

${ }^{17}$ The capital buffer used in the traffic-light model consists of subordinated debt, untaxed reserves and shareholders' equity.

${ }^{18}$ However, the small local non-life insurers and company-linked pension foundations are not included in the traffic light reporting system (Source FI's FAQ_-General). 


\begin{tabular}{|c|c|}
\hline & $\begin{array}{l}\text { regularly based experience gained from implementation. } \\
\text { FI issues various public reports discussing the strengths and weaknesses in the financial } \\
\text { system. These include both reports on specific issues on an ad-hoc basis, as well as regular } \\
\text { reports, e.g., the annual Risk Report that provides an overview of the financial sector and } \\
\text { the Supervisory Report that discusses emerging supervisory and regulatory developments. }{ }^{19} \\
\text { FI also publishes various statistics based on regular reporting from supervised entities. } \\
\text { FI publishes its annual reports, which outline its supervisory activities for the year. The DG } \\
\text { appears at least once a year before the Parliamentary Finance Committee. The supervisory } \\
\text { measures and the rationale for the measures taken are made public, subject to } \\
\text { confidentiality safeguards. } \\
\text { Criteria for assessing systemic importance have been developed and their application is } \\
\text { presently discussed, e.g., within the Nordic-Baltic supervisory fora. }{ }^{20} \text { At the time of } \\
\text { assessmwnt, no insurer is classified as a systematically important financial insitution in } \\
\text { Sweden. }\end{array}$ \\
\hline Assessment & Observed \\
\hline Comments & $\begin{array}{l}\text { FI adopts a transparent supervisory approach, supported by the Traffic Light model. It has } \\
\text { instituted structured processes for prioritization of supervisory activities and risk } \\
\text { assessment to ensure consistency in supervisory measures and decisions. FI has clear } \\
\text { accountabilities to the parliament, the industry and the public through various channels. } \\
\text { The authorities are advised to consider reviewing the impact of judicial review on the } \\
\text { ability of FI to make timely interventions to protect policyholders' interests. }\end{array}$ \\
\hline Princ & $\begin{array}{l}\text { Supervisory cooperation and information sharing } \\
\text { The supervisory authority cooperates and shares information with other relevant } \\
\text { supervisors subject to confidentiality requirements. }\end{array}$ \\
\hline Description & $\begin{array}{l}\text { Domestically, cooperation with Riksbank in respect of the insurance sector is informal. } \\
\text { Riskbank has dedicated resources dealing with macro-prudential issues arising from the } \\
\text { insurance sector. (S7 of FIO). } \\
\text { At the regional level, FI participates actively in policy deliberations at EU and cooperates } \\
\text { with relevant foreign authorities in coordinating supervision in line with EU Directives. Its } \\
\text { supervisory rules takes into consideration the guidelines and recommendations of the } \\
\text { European Insurance and Occupational Pensions Authority. In taking supervisory measures, } \\
\text { one of the considerations of FI is the impact on the stability of other financial systems in } \\
\text { the EEA. (S5 of FIO). } \\
\text { FI may disclose information to an authority if the Secrecy Act does not hinder the } \\
\text { disclosure. Confidential information shall not be disclosed to a foreign authority or } \\
\text { international organization. Secrecy applies to information concerning business or } \\
\text { management conditions, if the disclosure of such information may cause damage. } \\
\text { Economic or personal information concerning clients of an insurer is also subject to } \\
\text { secrecy. (Cpt } 8 \text {, s3 and cpt } 30, \text { s4 of Secrecy Act). } \\
\text { There are two exceptions to the Secrecy Act: a) disclosure which takes place in accordance }\end{array}$ \\
\hline
\end{tabular}

${ }^{19}$ The 2010 Supervisory Report describes the lessons learned from the financial crisis as well as general issues regarding consumer protection on the mortgage market, the advice of insurance intermediaries and how the interests of the customer are protected in investment funds and insurers.

${ }^{20}$ See http://www.fi.se/upload/43 Utredningar/40 Skrivelser/2010/NB-MoU public 170810.pdf. 


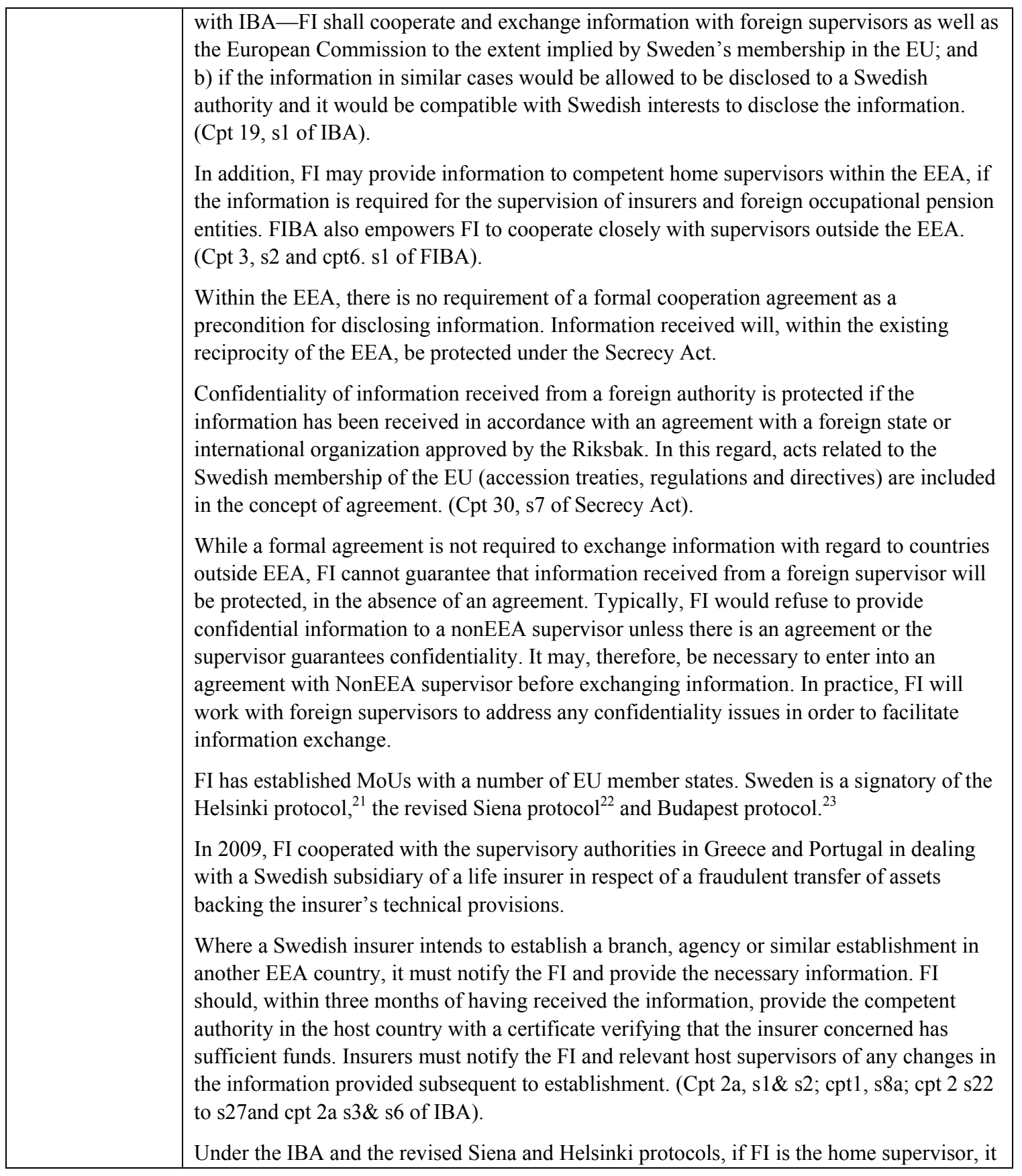

\footnotetext{
${ }^{21}$ A protocol relating to the collaboration of the supervisory authorities of the member states of EU. It concerns the application of Directive 1998/78/EC on the supervision of insurance undertakings which is part of an insurance group.

22 The revised Siena protocol outlines the minimum requirements for the exchange of information between the insurance supervisory authorities within the EEA.

${ }^{23}$ A protocol which provides a framework for the cooperation of competent authorities in the implementation of Directive 2003/41/EC on the activities and supervision of Institutions for Occupational retirement provision that operate cross-border.
} 


\begin{tabular}{|c|c|}
\hline & $\begin{array}{l}\text { is obligated to provide information to host supervisors. As a home supervisor, FI is } \\
\text { responsible for the financial supervision of a Swedish insurer. (Cpt 19, s1 of IBA). } \\
\text { While there is no legal obligation, FI may informally inform an EEA supervisor of its } \\
\text { intended supervisory measures against insurers with branches or cross-border activities in } \\
\text { Sweden or within the EEA. FI shall notify the host supervisor when initiating any } \\
\text { supervisory measures (including prohibiting or restricting disposal of the assets) against an } \\
\text { insurer carrying out business within the EEA. The supervisors in the countries where the } \\
\text { assets of the insurer are located shall also be informed. All supervisors within the EEA } \\
\text { shall be informed in case the license of an insurer is revoked. (Cpt 19, s11 \& s1 1a of IBA } \\
\text { and part IV s6 of the revised Siena protocol). } \\
\text { If an EEA insurer breaches Swedish laws and regulations, or is deemed unfit to carry on } \\
\text { business in Sweden, FI may require the insurer to take corrective action and inform the } \\
\text { home supervisor accordingly. If the insurer does not take the corrective action, FI may } \\
\text { suspend the insurer from accepting new business and inform the home supervisor. In urgent } \\
\text { cases, FI may take action without informing the home supervisor, in order to prevent } \\
\text { further violations. (Cpt } 3 \text {, s6 of FIBA). } \\
\text { FI is prepared to sign the IAIS multilateral MoU, pending approval from the government. } \\
\text { FI participates in a number of supervisory colleges established within EU and is the lead } \\
\text { supervisor in two insurance groups. }\end{array}$ \\
\hline Assessment & Observed \\
\hline Comments & $\begin{array}{l}\text { FI is empowered and regularly exchanges information with other supervisors, both within } \\
\text { and beyond EU, subject to confidentiality safeguards. Sweden is a signatory of the Helsinki } \\
\text { protocol, the revised Siena protocol and Budapest protocol. } \\
\text { The authorities are advised to expedite Sweden's accession to the IAIS multilateral MoU. }\end{array}$ \\
\hline \multicolumn{2}{|c|}{ The Supervised Entity } \\
\hline Principle 6. & $\begin{array}{l}\text { Licensing } \\
\text { An insurer must be licensed before it can operate within a jurisdiction. The requirements } \\
\text { for licensing are clear, objective and public. }\end{array}$ \\
\hline Description & $\begin{array}{l}\text { The IBA provides that insurance business can only be carried on by a public company } \\
\text { limited by shares or a mutual organization, }{ }^{25} \text { which have been licensed by FI. There is no } \\
\text { definition of "insurance business" under the IBA although civil courts, in connection with } \\
\text { prosecutions for illegal insurance activities, have defined the term. The FIBA defines } \\
\text { foreign insurers. (Cpt } 1, \mathrm{~s} 1 \text { of IBA and cpt } 1 \text { s5 of FIBA). } \\
\text { FI shall order a person who carries on insurance business without a license to: a) apply for } \\
\text { a license; b) make any arrangements demanded by FI; or c) cease to carry on the business. } \\
\text { If the person fails to comply with any order issued by FI he may be liable to pay an } \\
\text { administrative fine. (Cpt } 19, \text { s } 12 \text { and cpt } 21 \text { s } 2 \text { of IBA). } \\
\text { An EEA insurer may conduct insurance business in Sweden either from a secondary } \\
\text { establishment in Sweden or through cross-border operations, subject to certain notification }\end{array}$ \\
\hline
\end{tabular}

${ }^{24}$ CEIOPS list of groups for which a College of supervisors is in place.

${ }^{25}$ Chapter 2 of the IBA sets out detailed provisions regarding the formation and incorporation of an insurance company limited by shares and a mutual insurer. An insurer who is not formed in accordance with these provisions cannot be granted a licence. 


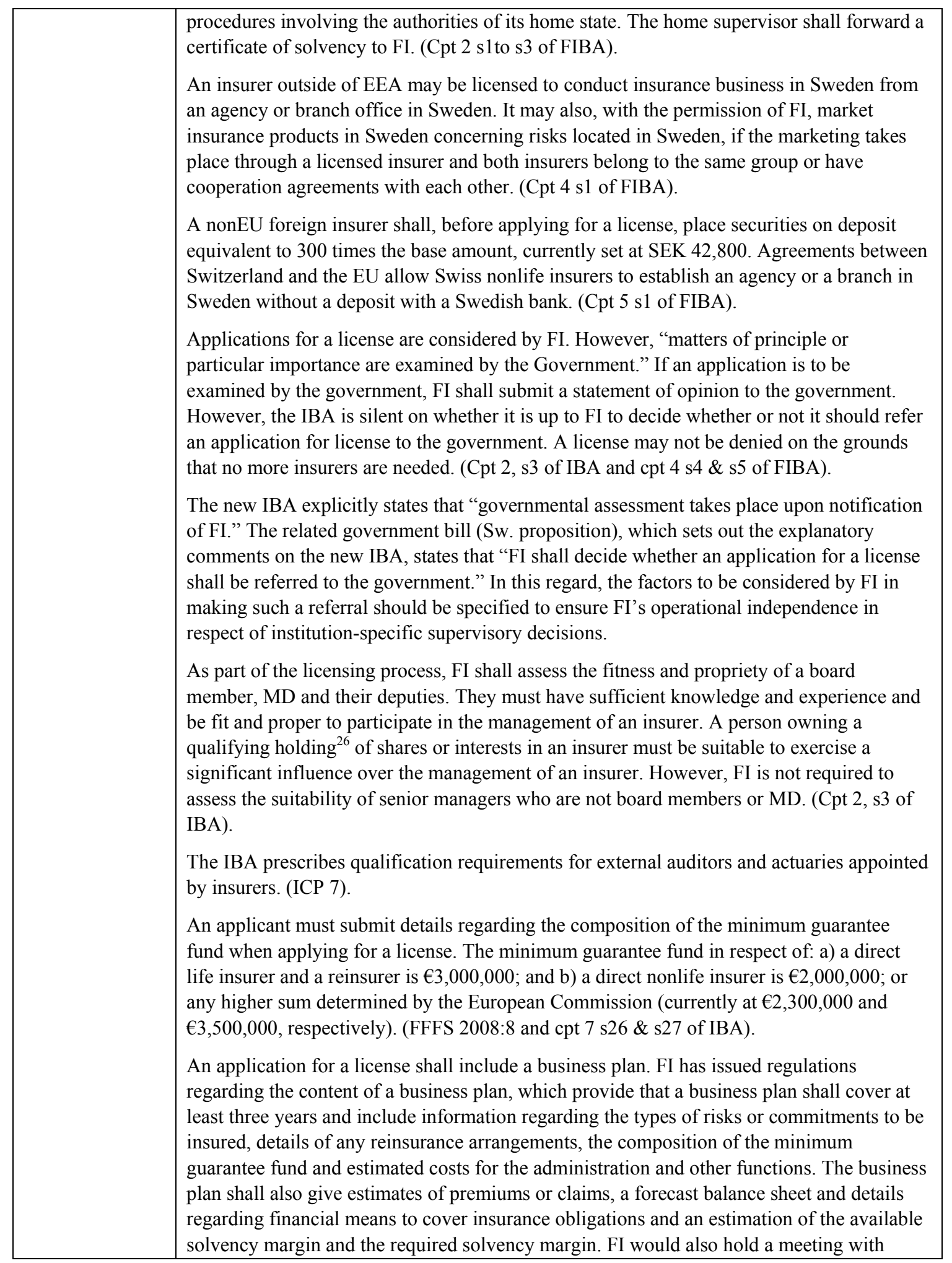

${ }^{26}$ Defined in Chapter 1, Section 9i of the IBA. 


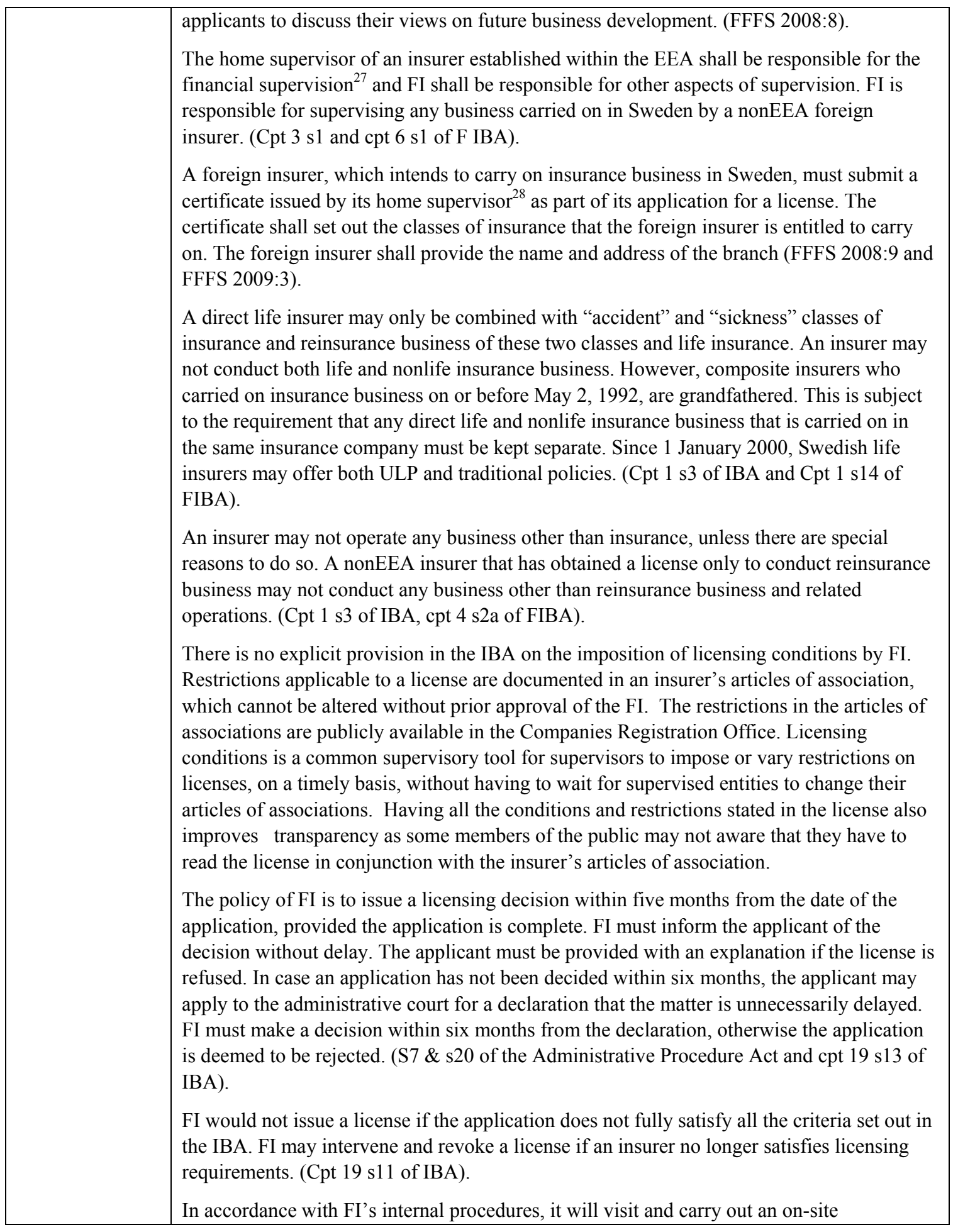

\footnotetext{
${ }^{27}$ Financial supervision includes monitoring the solvency, technical provisions and debt service coverage.

${ }^{28}$ The certificate from the home supervisor provides details regarding available solvency margin, required solvency margin and the composition of the minimum guarantee fund or equivalent.
} 


\begin{tabular}{|c|c|}
\hline & $\begin{array}{l}\text { investigation of a newly established insurer within one year from the date of the grant of } \\
\text { the license. FI would, inter alia, review the register of assets used to cover the technical } \\
\text { provisions, the board minutes, the policies and guidelines, financial forecasts and } \\
\text { prognosis, etc. }\end{array}$ \\
\hline Assessment & Largely Observed \\
\hline Comments & $\begin{array}{l}\text { The licensing policy, criteria, and procedures are clear and transparent. However, the IBA } \\
\text { provides for government involvement in the licensing of specific institutions. Senior } \\
\text { managers (except MD) are not subject to fit and proper assessment. } \\
\text { The authorities are advised to: } \\
\text { a) review the government's role in the licensing process under the IBA; } \\
\text { b) extend the fit and proper assessment to senior management of insurers; } \\
\text { c) consider empowering FI to impose licensing conditions; and } \\
\text { d) consider having a definition of insurance business in the IBA. }\end{array}$ \\
\hline Principle 7. & $\begin{array}{l}\text { Suitability of persons } \\
\text { The significant owners, board members, senior management, auditors and actuaries of an } \\
\text { insurer are fit and proper to fulfill their roles. This requires that they possess the appropriate } \\
\text { integrity, competency, experience and qualifications. }\end{array}$ \\
\hline Description & $\begin{array}{l}\text { A board member and MD (In this report, these terms include alternate board members and } \\
\text { vice MDs) shall have sufficient knowledge and experience and be fit and proper to manage } \\
\text { an insurer's operations, both at the licensing stage and on an on-going basis. A natural or } \\
\text { legal person, who has or intends to have a qualifying holding in an insurer, must be fit and } \\
\text { proper to exercise significant influence over the insurer. (Cpt } 2 \text { s3 of IBA). } \\
\text { The IBA and the Supplementary Supervision of Financial Conglomerates Act (SSFCA) } \\
\text { provide that the management of an insurance holding company or financial conglomerate } \\
\text { shall have sufficient knowledge and experience and be fit and proper. (Cpt } 7 \text { s9 of IBA and } \\
\text { cpt } 5 \text { s16 of SSFCA). } \\
\text { Any person who is disqualified from carrying on business under the Trading Prohibition } \\
\text { Act may not hold office as a board member or MD of an insurer. (Cpt } 8 \text { s4 of IBA). } \\
\text { FI is not empowered to assess the suitability of senior manager of insurers, who are not } \\
\text { appointed as board members or MD. However, FI may order an insurer to take necessary } \\
\text { measures if a senior manager is deemed to be unfit. (Cpt } 19 \text { s11h of IBA). } \\
\text { FI has no power to remove auditors or actuaries, nor do they have to be approved. It is the } \\
\text { responsibility of an insurer to ensure that the auditor and actuaries they appoint holds the } \\
\text { required qualifications. FI may intervene if an auditor or actuary is deemed unfit or } \\
\text { improper. } \\
\text { An insurer may only appoint an approved auditor or chartered accountant as its external } \\
\text { auditor. (ICP 1) The auditor shall possess appropriate knowledge and experience, taking } \\
\text { into consideration the nature and scope of the insurer's operations. (Cpt } 10 \text { s3 of IBA). } \\
\text { An actuary appointed by an insurer shall have the requisite knowledge and experience } \\
\text { having regard of the nature and scope of the insurer's business and satisfy the criteria set } \\
\text { out in FFFS } 2007: 21 \text {. These include, inter alia, meeting the education requirements set by } \\
\text { the Actuarial Society of Sweden or the International Association of Actuaries and having at } \\
\text { least three years practical experience. An actuary qualified outside of Sweden must have } \\
\text { sufficient knowledge of Swedish to understand applicable Swedish insurance laws and }\end{array}$ \\
\hline
\end{tabular}




\begin{tabular}{|c|c|}
\hline & 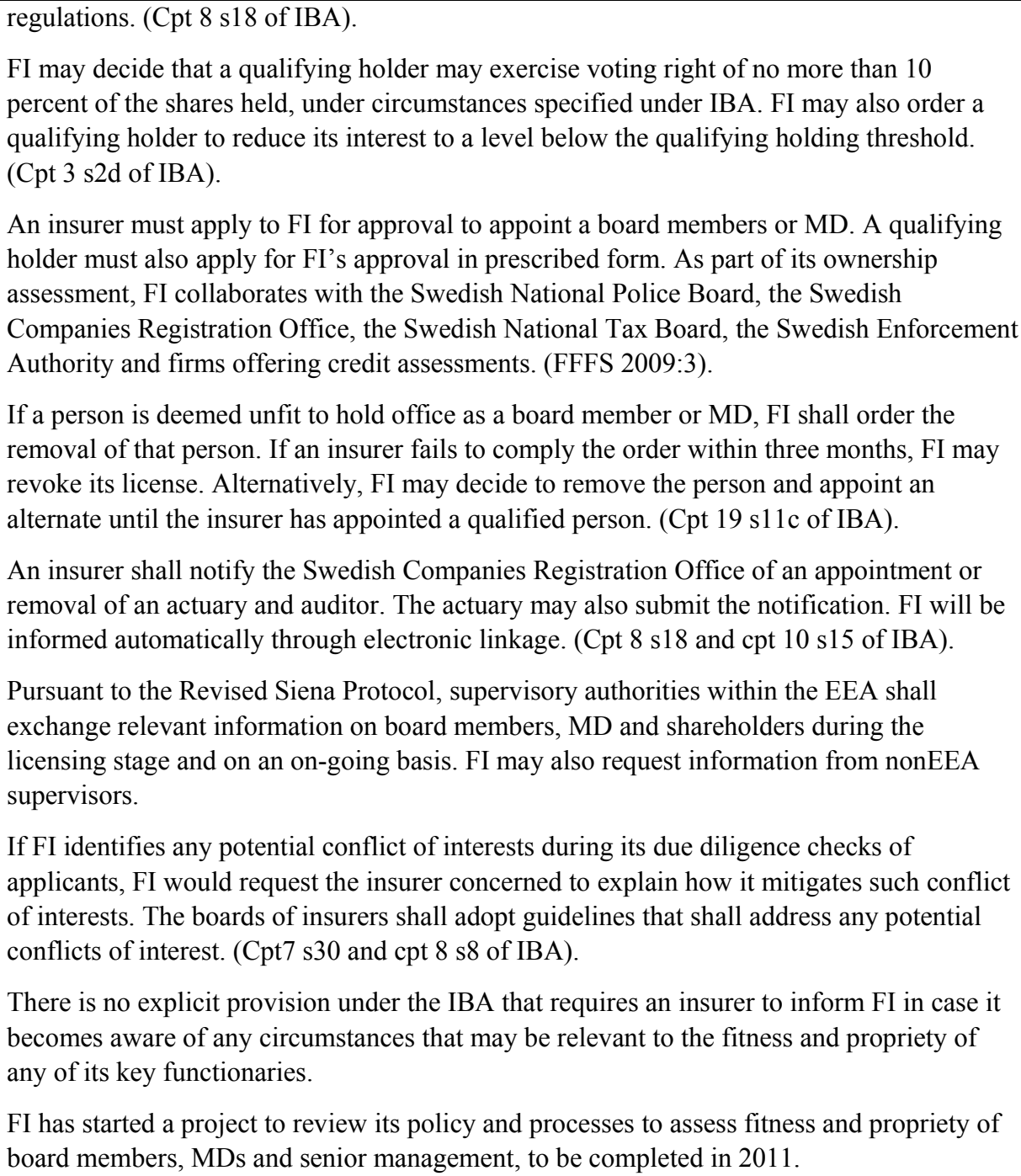 \\
\hline Assessment & Largely Observed \\
\hline Comments & $\begin{array}{l}\text { FI conducts due diligence checks on board members, MDs as well as qualifying holders of } \\
\text { insurers and may remove such persons if they are no longer fit and proper. FI has no power } \\
\text { to remove auditors or actuaries, nor do they have to be approved. FI is also not empowered } \\
\text { to assess senior managers (who are not MD). FI may, however, take action indirectly by } \\
\text { requiring insurers to take corrective action if it finds that such persons do not meet } \\
\text { regulatory requirements. } \\
\text { The authorities should introduce regulations including: } \\
\text { a) explicit provision for FI to assess the fitness and propriety of senior management of } \\
\text { insurers as well as their auditors and actuaries; and } \\
\text { b) to require insurers to notify FI of circumstances that may affect the fitness and } \\
\text { propriety of its board members, MD senior managers, auditors and actuaries. }\end{array}$ \\
\hline
\end{tabular}




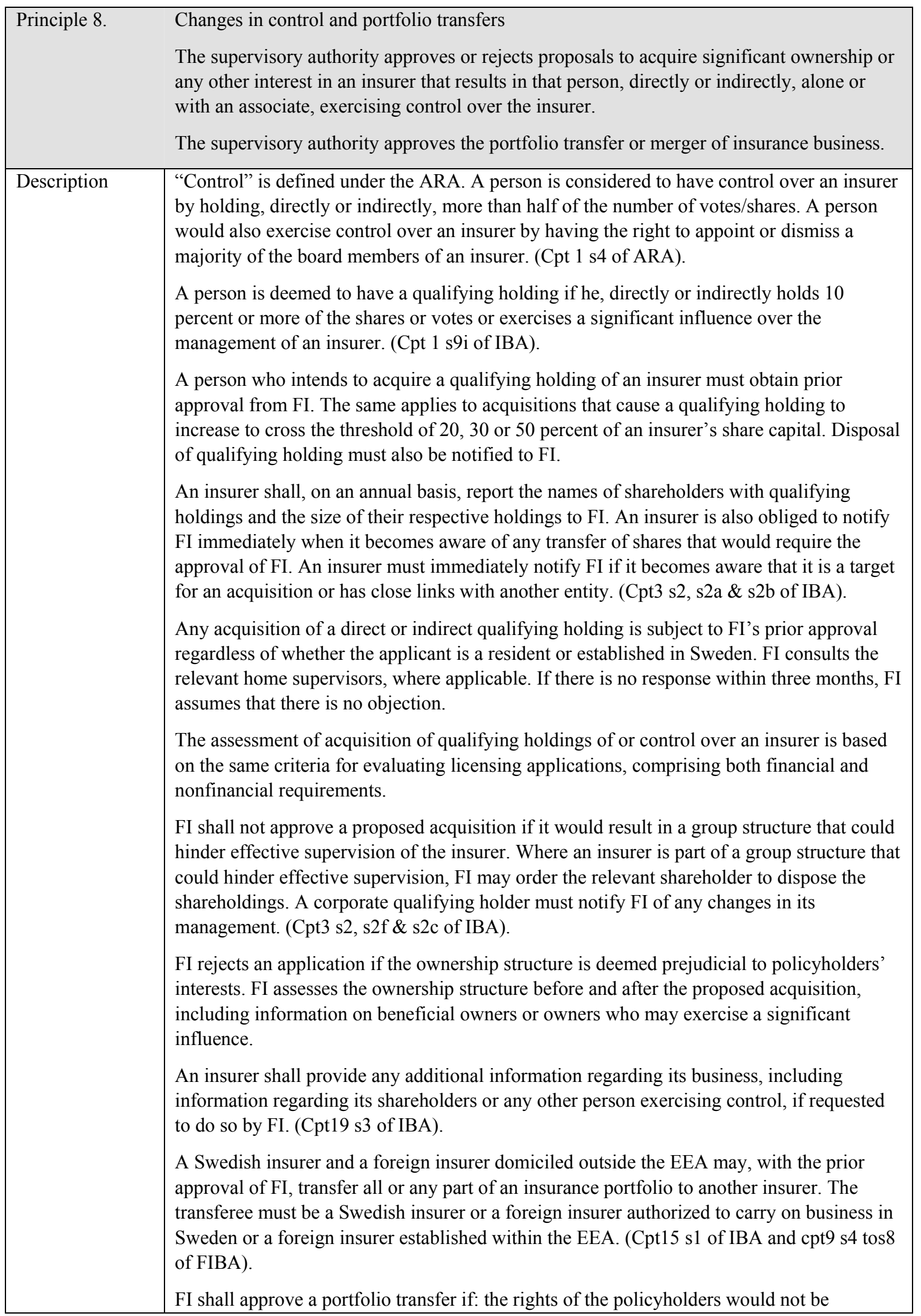




\begin{tabular}{|c|c|}
\hline & $\begin{array}{l}\text { adversely affected; the transferee has an adequate available solvency margin after the } \\
\text { transaction; and the competent supervisor in the country where the risks are located or } \\
\text { where the commitments will be discharged has consented or not objected to the portfolio } \\
\text { transfer. (Cpt15 s3 \&s4 of IBA). } \\
\text { An insurer domiciled within the EEA may, transfer all or any part of an insurance portfolio } \\
\text { in Sweden, to a Swedish or foreign insurer. The relevant home supervisor shall consult FI } \\
\text { regarding the proposed portfolio transfer. FI shall consent to the transfer if the rights of the } \\
\text { policyholders are not adversely affected and the transferee has adequate solvency after the } \\
\text { transaction. (Cpt } 9 \text { s } 2 \text { s } 3 \text { of FIBA). } \\
\text { During } 2009 \text {, FI decided to disallow the conversion of a mutual insurer into a corporate } \\
\text { entity. FI concluded that the regulations governing conversions must be clarified in order to } \\
\text { increase the ability of policyholders to influence the conversion. In reviewing whether the } \\
\text { rights of policyholders have not been compromised, FI critically evaluates the assumptions } \\
\text { made about long-term sustainability of the new entity. }\end{array}$ \\
\hline Assessment & Observed \\
\hline Comments & $\begin{array}{l}\text { The regulatory requirements for acquisition and changes in control as well portfolio } \\
\text { transfer are clearly set out under the IBA and FIBA. FI will not approve a portfolio transfer } \\
\text { unless it is satisfied that the rights of the policyholders would not be adversely affected. }\end{array}$ \\
\hline Principle 9. & $\begin{array}{l}\text { Corporate governance } \\
\text { The corporate governance framework recognizes and protects rights of all interested } \\
\text { parties. The supervisory authority requires compliance with all applicable corporate } \\
\text { governance standards. }\end{array}$ \\
\hline Description & $\begin{array}{l}\text { Sweden adopts a unitary board of directors (board) system. The IBA requires that at least } \\
\text { half of the board members of insurers are nonexecutive directors. There is no definition of } \\
\text { independent directors and no requirement on the independence of directors. It is generally } \\
\text { recognized that effective independent directors contribute to better checks-and-balance as } \\
\text { well as objectivity to board decisions. } \\
\text { The IBA sets out provisions regarding the management of an insurer. However, the term } \\
\text { "senior management" is not defined under Swedish laws. Thus, there is no provision } \\
\text { regarding the responsibilities of senior managers who are not appointed as MD. } \\
\text { FI has issued guidelines on corporate governance of financial undertakings, including } \\
\text { insurers. The guidelines provide high-level principles for corporate governance, internal } \\
\text { controls, risk management, compliance, internal audit and outsourcing arrangements. (Cpt8 } \\
\text { of IBA and FFFS2005:1). } \\
\text { FI examines insurers' corporate governance as part of its on-going supervision and is } \\
\text { empowered to intervene }{ }^{29} \text { if an insurer's corporate governance is inadequate, taking into } \\
\text { account the nature and scale of its business. (Cpt19 s1 and s11 of IBA). } \\
\text { The IBA sets out the respective roles and accountabilities of the board and MD of an } \\
\text { insurer. The MD cannot be appointed chairman of the board. The board shall adopt } \\
\text { strategies and objectives for the insurer including guidelines on: technical provisions, } \\
\text { investment policy and handling of conflicts of interest. The board shall ensure that the }\end{array}$ \\
\hline
\end{tabular}

${ }^{29}$ In 2009, FI issued a reprimand against a Swedish non-life insurer and imposed a fine of SEK 5 million. FI had found, inter alia, that its corporate governance and internal controls were inadequate. The management structure and accountabilities were complex and ill-defined. In addition, it had failed to submit quarterly and annual reports on an accurate and timely basis. The insurer took remedial action, as required by FI. 


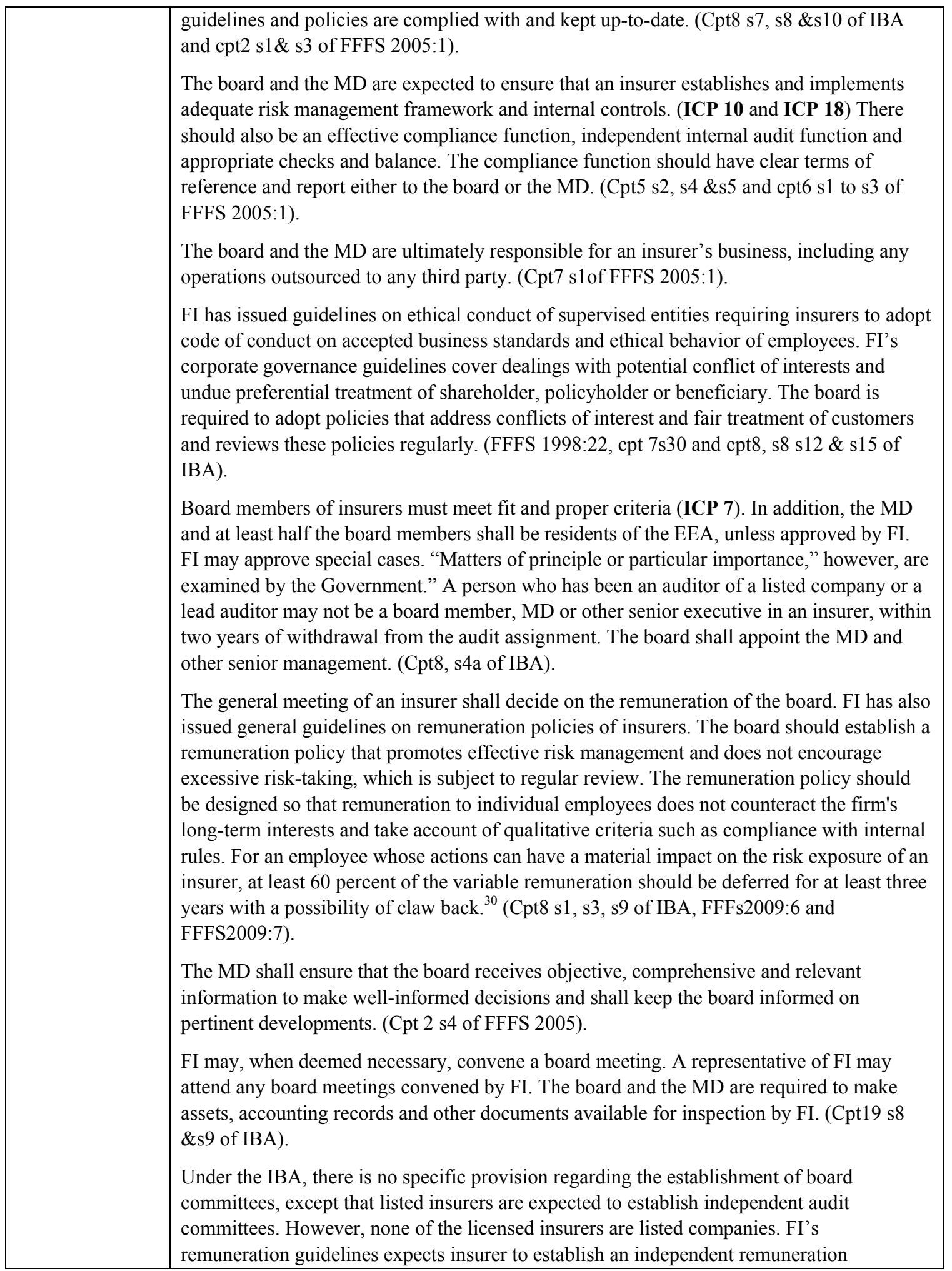

${ }^{30}$ An insurer should endeavour to ensure that employees do not use risk hedging strategies or insurances to mitigate the effects of an adjustment/cancellation of a deferred payment. 


\begin{tabular}{|c|c|}
\hline & $\begin{array}{l}\text { committee or appoint a nonexecutive director to be responsible for preparing significant } \\
\text { remuneration decisions and monitoring the application of the remuneration policy. (Cpt2 s3 } \\
\text { of FFFS_2009:6). } \\
\text { There is scope for enhancing the effectiveness of the board through the establishment of } \\
\text { board committees such as audit committees, risk management committee or nomination } \\
\text { committee, taking into consideration the nature, scale and complexity of an insurer's } \\
\text { operation, regardless of whether an insurer is listed on a regulated market. In addition, } \\
\text { insurers should establish policies and procedures to assess the effective of their boards and } \\
\text { board members. } \\
\text { While insurers must appoint at least one actuary, there is no explicit provision regarding the } \\
\text { rights of an actuary to have direct access to the board or board committees. An actuary also } \\
\text { does not have specific duty to report to the board on a timely basis. In practice, most } \\
\text { actuaries have direct access to the board. } \\
\text { FI has started a project to consider the approach to assess the board members of insurers. }\end{array}$ \\
\hline Assessment & Largely Observed \\
\hline Comments & $\begin{array}{l}\text { The corporate governance framework for insurers is broadly in line with ICP 9. FI } \\
\text { examines insurers' corporate governance practices during its on-site inspections and has } \\
\text { taken necessary supervisory measures, where appropriate. The authorities are advised to } \\
\text { strengthen the corporate governance regime for insurers to reflect international standards } \\
\text { and promote the objectivity and effectiveness of the board of directors. } \\
\text { The authorities are advised to establish clear corporate governance standards for insurers } \\
\text { on: } \\
\text { a) The minimum level of independent directors and criteria for independence; } \\
\text { b) Establishment of relevant board committees, taking into account the nature, scale and } \\
\text { c) Policies and procedures to assess the effectiveness of their boards; } \\
\text { d) The role and accountabilities of senior managers; and } \\
\text { e) Providing actuaries with direct access to the board and board committee on a timely } \\
\text { basis. }\end{array}$ \\
\hline Principle 10. & $\begin{array}{l}\text { Internal controls } \\
\text { The supervisory authority requires insurers to have in place internal controls that are } \\
\text { adequate for the nature and scale of the business. The oversight and reporting systems } \\
\text { allow the board and management to monitor and control the operations. }\end{array}$ \\
\hline Description & $\begin{array}{l}\text { The IBA holds the board remains ultimately responsible for the organization and } \\
\text { management of an insurer. FI's guidelines on corporate governance outline FI's expectation } \\
\text { of insurers in establishing and maintaining sound internal controls. (Cpt8 s7 of IBA and cpt } \\
2 \text { s1 and cpt } 3 \text { of FFFs2005:1). } \\
\text { An insurer's framework for internal controls should include arrangements for delegating } \\
\text { authority and responsibility, and the segregation of duties. (Cpt } 3 \text { s4 of FFFs2005:1). } \\
\text { The board should provide suitable prudential oversight and establish an effective risk } \\
\text { management system that addresses an insurer's key risk exposures. In this regard, the board } \\
\text { is expected to establish an independent risk management function. (ICP 18) (Cpt } 4 \text { s3 of } \\
\text { FFFs2005:1). }\end{array}$ \\
\hline
\end{tabular}




\begin{tabular}{|c|c|}
\hline & 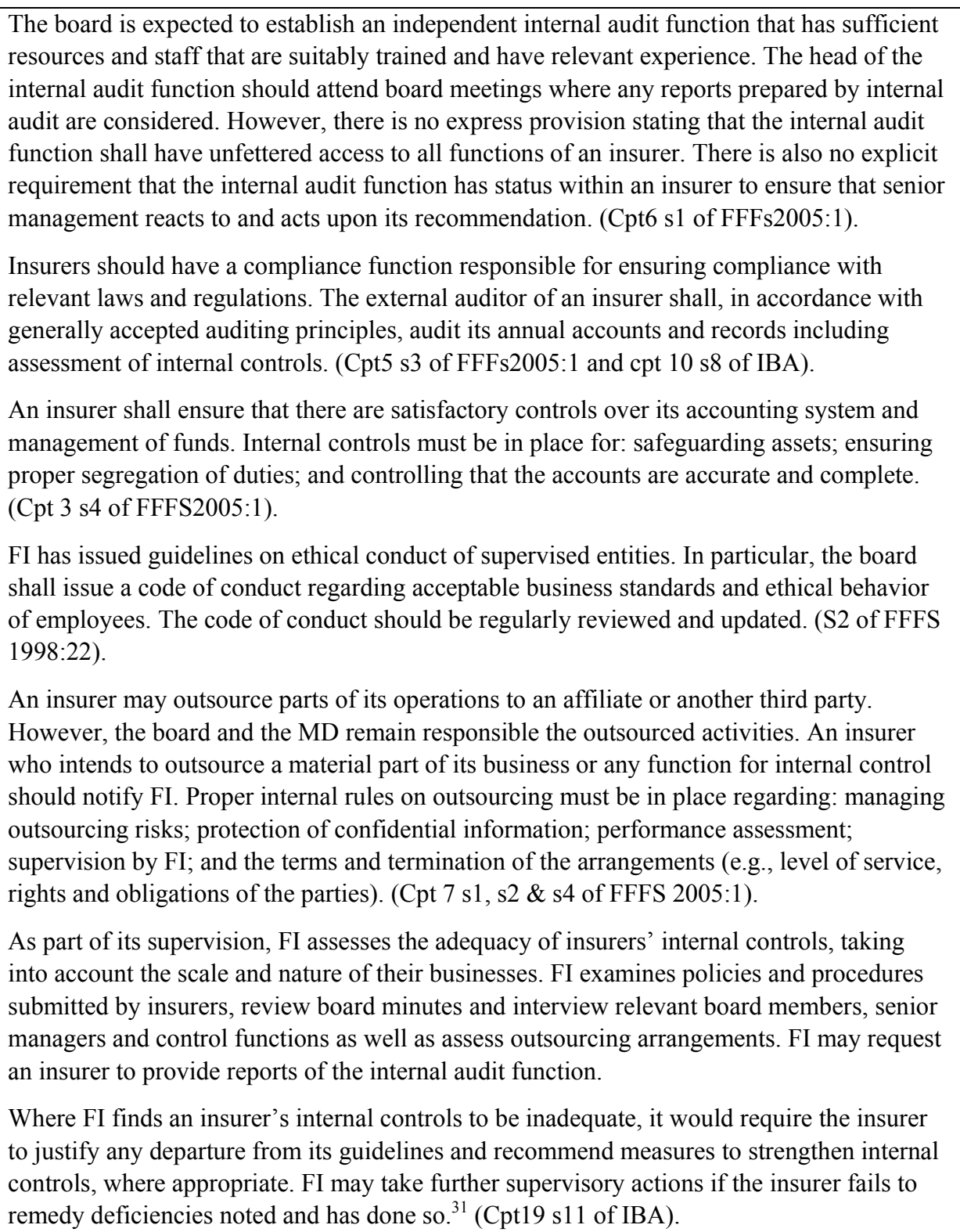 \\
\hline Assessment & Observed \\
\hline Comments & $\begin{array}{l}\text { FI supervises and assesses insurers' internal controls in line with the requirements under } \\
\text { the IBA and its corporate governance guidelines. It is empowered and has taken } \\
\text { supervisory measures against insurers for deficiencies in internal controls. } \\
\text { To strengthen the checks and balances of insurers' operations, FI is advised to consider } \\
\text { adopting explicit provisions to ensure that internal auditors have unfettered access to the } \\
\text { board and senior management as well as appropriate status to ensure that senior }\end{array}$ \\
\hline
\end{tabular}

${ }^{31}$ FI found a non-life mutual insurer had committed a breach of applicable laws and regulations, including accounting procedures and the submission of quarterly and annual reports to FI. FI issued a warning and imposed a fine of SEK 2,000,000. 


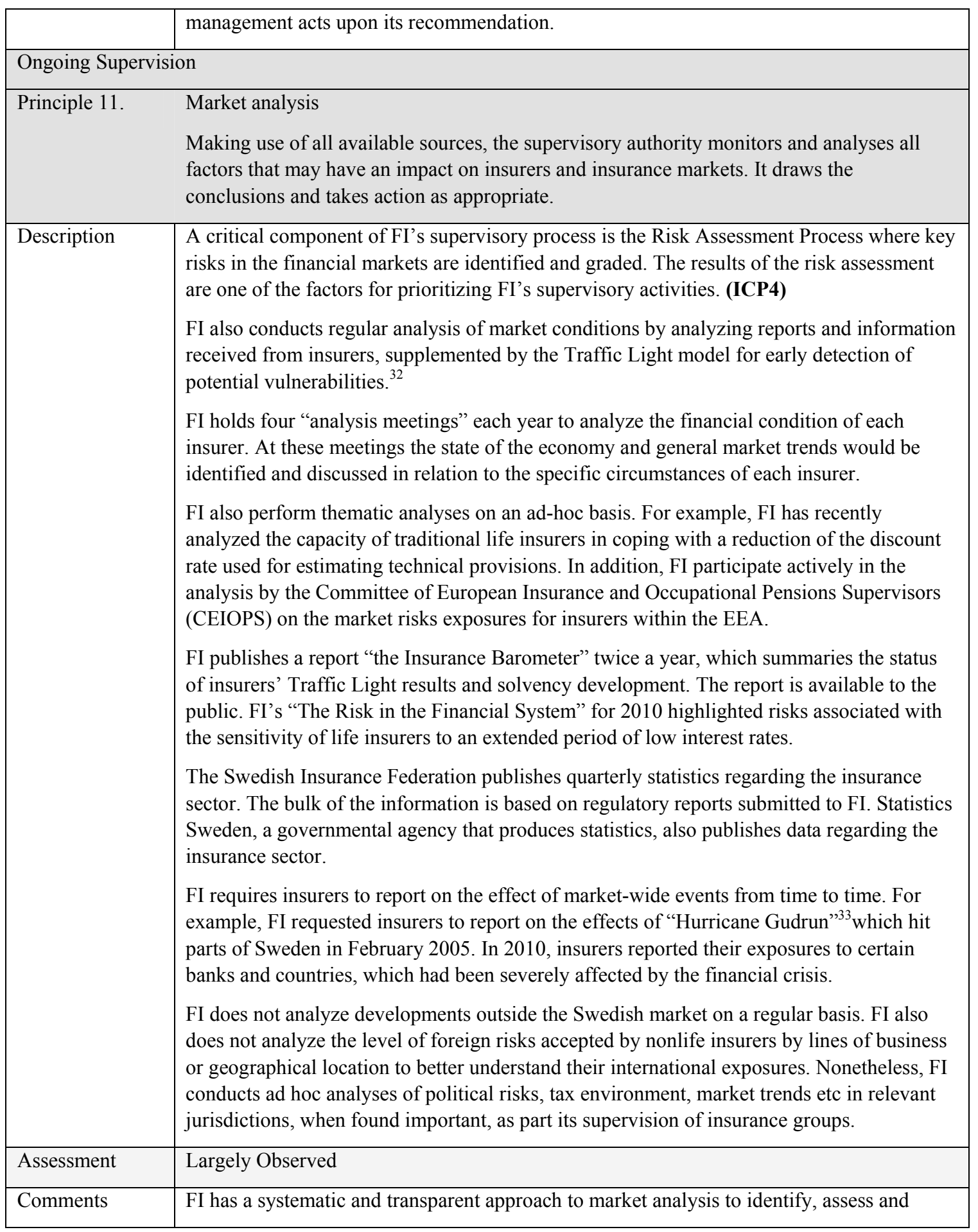

${ }^{32}$ In 2007 a friendly society, received a red light in the Traffic Light model. FI's investigation revealed that the friendly society had incurred borrowings in order to purchase real estate, which is unlawful. FI ordered the friendly society to take corrective measures.

${ }^{33}$ See http://www.thelocal.se/823/20050109/ 


\begin{tabular}{|c|c|}
\hline & $\begin{array}{l}\text { mitigate risks to the insurance sector. The publication of insurance and other market } \\
\text { statistics facilitate insurers' understanding of systemic developments that have implications } \\
\text { for their operations. Due to limited resources, FI does not analyze developments outside } \\
\text { the Swedish market on a regular basis. It would perform such analysis, when found } \\
\text { important, as part of its group supervision. } \\
\text { It is important that FI enhance its capacity and resources to analyze the developments } \\
\text { outside the Swedish market on a regular basis including Swedish insurers' exposures to } \\
\text { foreign risks. }\end{array}$ \\
\hline Principle 12. & $\begin{array}{l}\text { Reporting to supervisors and off-site monitoring } \\
\text { The supervisory authority receives necessary information to conduct effective off-site } \\
\text { monitoring and to evaluate the condition of each insurer as well as the insurance market. }\end{array}$ \\
\hline Description & 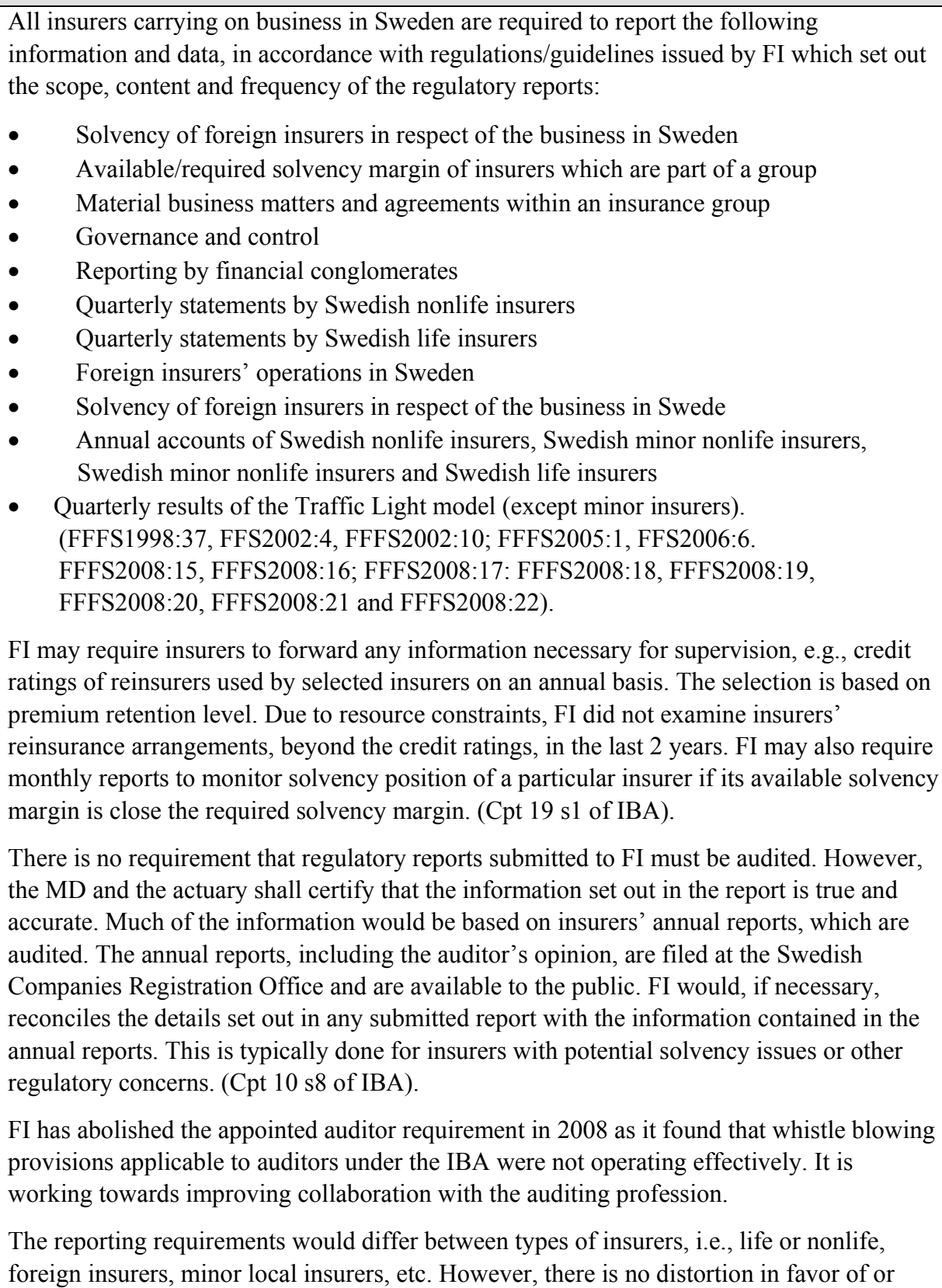 \\
\hline
\end{tabular}




\begin{tabular}{|c|c|}
\hline & 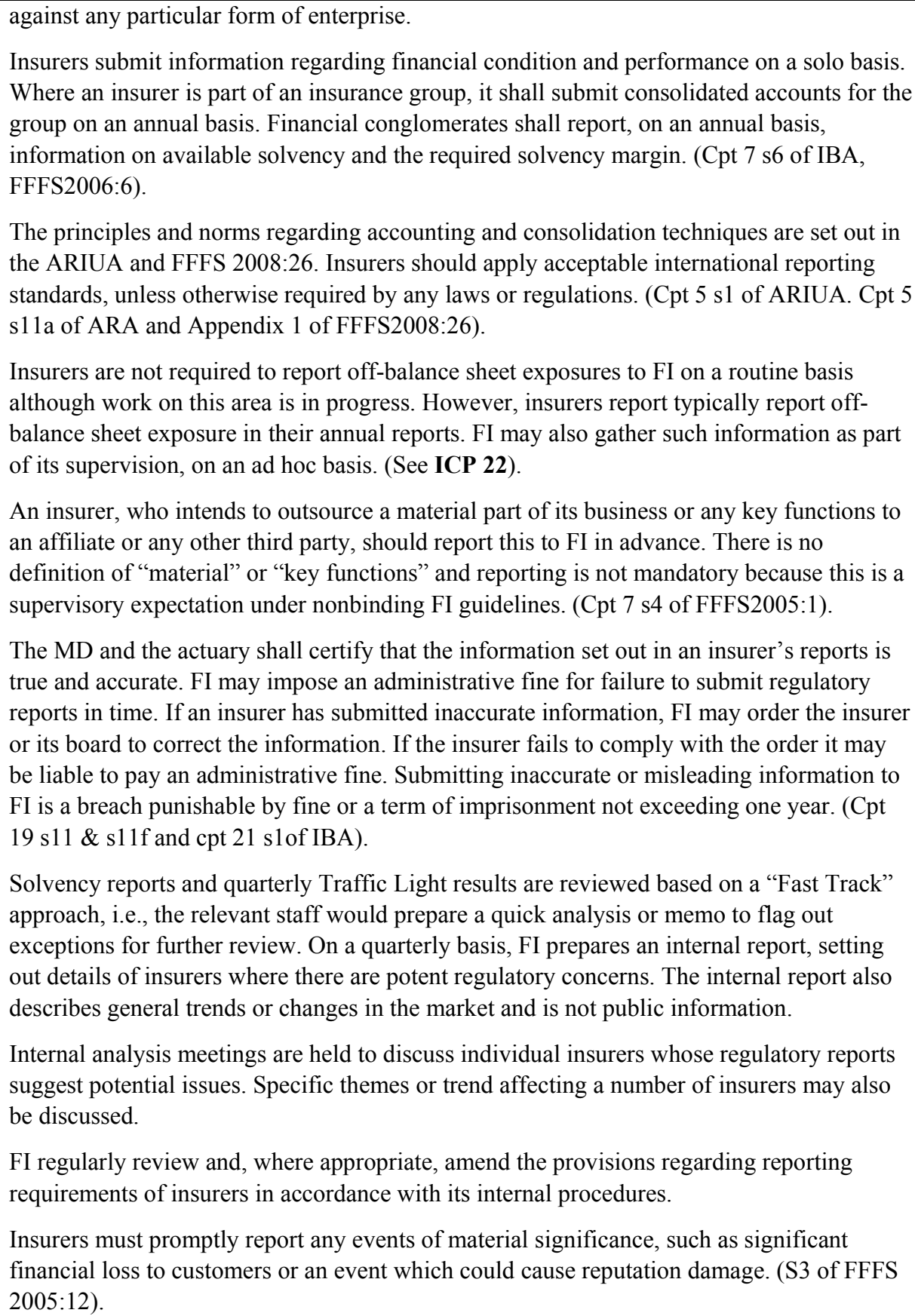 \\
\hline Assessment & Largely Observed \\
\hline Comments & $\begin{array}{l}\text { FI has issued regulations and guidelines setting out the scope, content and frequency of } \\
\text { reports by different types of insurers. It is also empowered to require additional reports } \\
\text { necessary for effective supervision or timely intervention. As the regulatory returns are not } \\
\text { audited, FI has to reconcile the returns with insurers' audited annual reports. Insurers are } \\
\text { not required to report outsourcing arrangements as well as derivatives and off-balance sheet } \\
\text { transaction to FI regularly. FI does not have adequate resources to conduct adequate off-site } \\
\text { monitoring for all licensed insurers. }\end{array}$ \\
\hline
\end{tabular}




\begin{tabular}{|c|c|}
\hline & $\begin{array}{l}\text { FI is advised to: } \\
\text { a) formulate a more robust risk-based supervision approach based on both the impact and } \\
\text { probability of failure, supported by appropriate baseline supervision; } \\
\text { b) review the adequacy of resources for off-site monitoring; } \\
\text { c) establish clear regulatory requirement for insurers to report their reinsurance strategy } \\
\text { and program, outsourcing arrangements and off-balance sheet exposures including } \\
\text { derivatives transactions; and } \\
\text { d) require annual regulatory returns of insurers to be audited. }\end{array}$ \\
\hline Principle 13. & $\begin{array}{l}\text { On-site inspection } \\
\text { The supervisory authority carries out on-site inspections to examine the business of an } \\
\text { insurer and its compliance with legislation and supervisory requirements. }\end{array}$ \\
\hline Description & 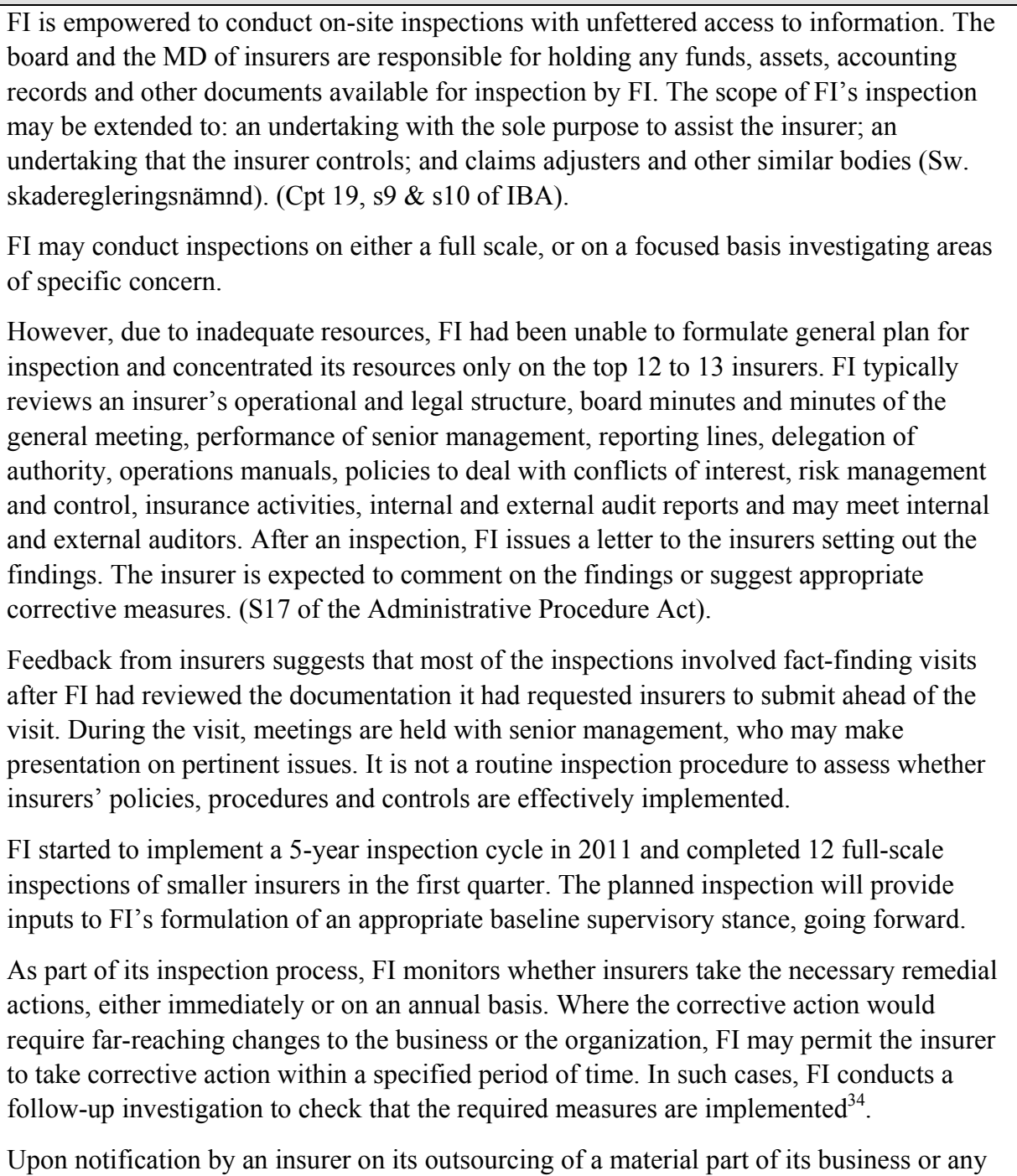 \\
\hline
\end{tabular}

${ }^{34}$ In May 2009, FI issued a sanction against a Swedish non-life insurer for inadequacies in corporate governance, internal controls, and reporting to FI. This was followed up by an on-site inspection during 2010. 


\begin{tabular}{|c|c|}
\hline & $\begin{array}{l}\text { function, FI would ensure that the outsourcing arrangement provides for inspection by FI. } \\
\text { FI may take action against an insurer if it has outsourced functions without providing for } \\
\text { the supervision of FI. } \\
\text { An EU home supervisor may, after notifying FI, inspect a secondary establishment of an } \\
\text { EU insurer in Sweden. FI is entitled to participate in the inspection. FI supervises Swedish } \\
\text { insurers' branches in the EEA, within the resources available under the current priorities. } \\
\text { (Cpt 3, s5 of FIBA). }\end{array}$ \\
\hline Assessment & Largely Observed \\
\hline Comments & $\begin{array}{l}\text { FI conducts both full scale and focused inspections. It has also conducted joint inspections } \\
\text { with foreign supervisors. It does not have adequate resources to implement baseline } \\
\text { supervision for a large number of supervised insurers and intermediaries, as part of its risk- } \\
\text { based supervision. Effective inspection should go beyond a checklist approach in order to } \\
\text { better understand insurers' operations and risks. } \\
\text { FI is advised to improve the robustness of on-site inspection and ensure that the planned } \\
\text { baseline onsite supervisory program is supported by adequate supervisory resources. }\end{array}$ \\
\hline Principle 14. & $\begin{array}{l}\text { Preventive and Corrective Measures } \\
\text { The supervisory authority takes preventive and corrective measures that are timely, suitable } \\
\text { and necessary to achieve the objectives of insurance supervision. }\end{array}$ \\
\hline Description & $\begin{array}{l}\text { FI can take a range of preventive and corrective actions if an insurer fails to operate in a } \\
\text { manner that is consistent with sound business practices or regulatory requirements. } \\
\text { As an initial measure, FI may enter into discussions with the insurer to find an acceptable } \\
\text { solution or issue a report setting out the specific areas of concern. Where appropriate, FI } \\
\text { may take enforcement actions and impose sanctions under the IBA or FIBA. (ICP 15). } \\
\text { If an insurer's situation becomes worse or if it ignores FI's informal requests to take } \\
\text { remedial measures, FI has a wide range of powers to adopt a progressive escalation of } \\
\text { action or remedial measures: } \\
\text { Swedish insurers } \\
\text { - Calling a board meeting or an extraordinary general meeting and attend such meetings. } \\
\text { (Cpt } 19 \text { s8 \&s9 of IBA). } \\
\text { - Intervention against a qualifying holder - FI may decide that a qualifying holder may } \\
\text { only vote for shares at a general meeting, which represents less than } 10 \text { percent of the } \\
\text { total number of shares. FI may also request the court to appoint a suitable person to } \\
\text { represent the shares or order the qualifying holder to dispose its interest below the } \\
\text { threshold for a qualifying holding. (Cpt } 3 \text { s2, s2e of IBA). } \\
\text { - Ordering an insurer or a financial conglomerate to take appropriate action against an } \\
\text { officer deemed unfit to be involved in the management. (Cpt } 19 \text { s11h of IBA and Cpt } \\
\text { s2 of SSFCA). } \\
\text { - Replacement of board members or the MD of an insurer, an insurance holding } \\
\text { company or a financial conglomerate. (Cpt } 19 \text { s11c \&s11h of IBA and Cpt } 2 \mathrm{~s} 2 \text { of } \\
\text { - SSFCA) } \\
\text { Imposing a fine not exceeding SEK } 100,000 \text { for late filing. (Cpt } 19 \text { s11f of IBA and } \\
\text { cpt7 s4 of SSFCA). } \\
\text { - Issue a reprimand, subject to the government's review. (Cpt } 19 \text { s11 of IBA). } \\
\text { Foreign insurers within the EEA } \\
\text { Order a foreign insurer to remedy a breach of FIBA or related regulations. (Cpt } 3 \mathrm{~s} 6 \text { of }\end{array}$ \\
\hline
\end{tabular}




\begin{tabular}{|c|c|}
\hline & 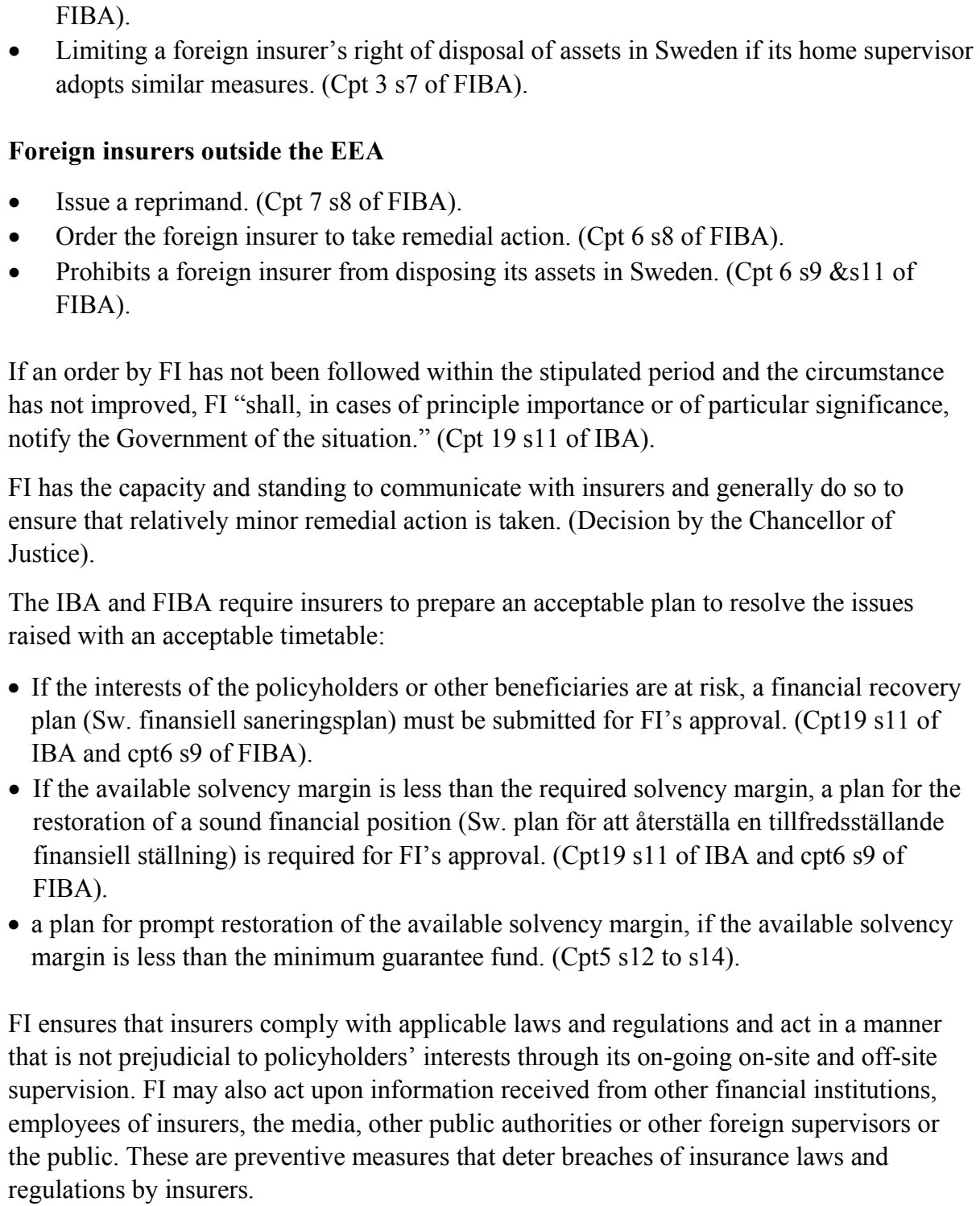 \\
\hline Assessment & Observed \\
\hline Comments & $\begin{array}{l}\text { FI is empowered to take a progressive escalation of preventive measures to address } \\
\text { emerging supervisory concerns. }\end{array}$ \\
\hline Principle 15. & $\begin{array}{l}\text { Enforcement or sanctions } \\
\text { The supervisory authority enforces corrective action and, where needed, imposes sanctions } \\
\text { based on clear and objective criteria that are publicly disclosed. }\end{array}$ \\
\hline Description & $\begin{array}{l}\text { For more serious infringements or where insurers ignore FI's orders or the situation is } \\
\text { deteriorating, FI is empowered to take wide range of enforcement actions or to impose } \\
\text { sanctions, including: } \\
\text { - Ordering an insurer to adopt any particular measures or refrain or desist from taking } \\
\text { any specific actions. (Cpt 21, s2 of IBA). } \\
\text { - Revocation of license. Questions about license forfeiture are considered by FI. } \\
\text { "Matters of principle or special importance, however, are examined by the }\end{array}$ \\
\hline
\end{tabular}




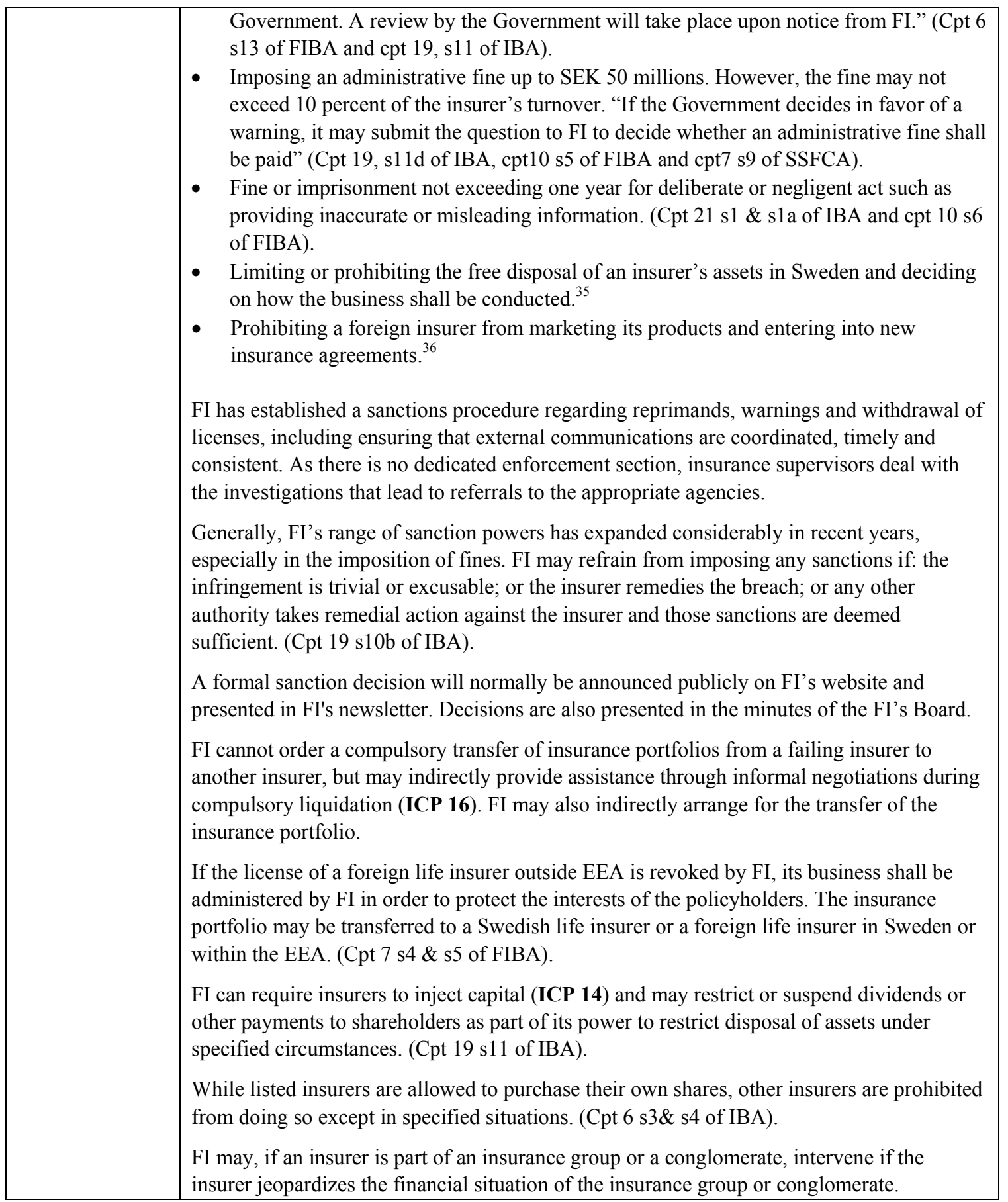

${ }^{35}$ Arising from an inspection of a Swedish life insurer in 2009, FI ordered the insurer to submit a financial recovery plan. The insurer stated in the plan that its assets would be returned on or before a specified date. FI deemed the plan to be insufficient and decided to prohibit the insurer from disposing its assets without the consent of FI until the specified date.

${ }^{36}$ Before declaring that the licence of the insurer above was revoked, FI issued a decision preventing the insurer from entering into any new insurance agreements. 


\begin{tabular}{|c|c|}
\hline & 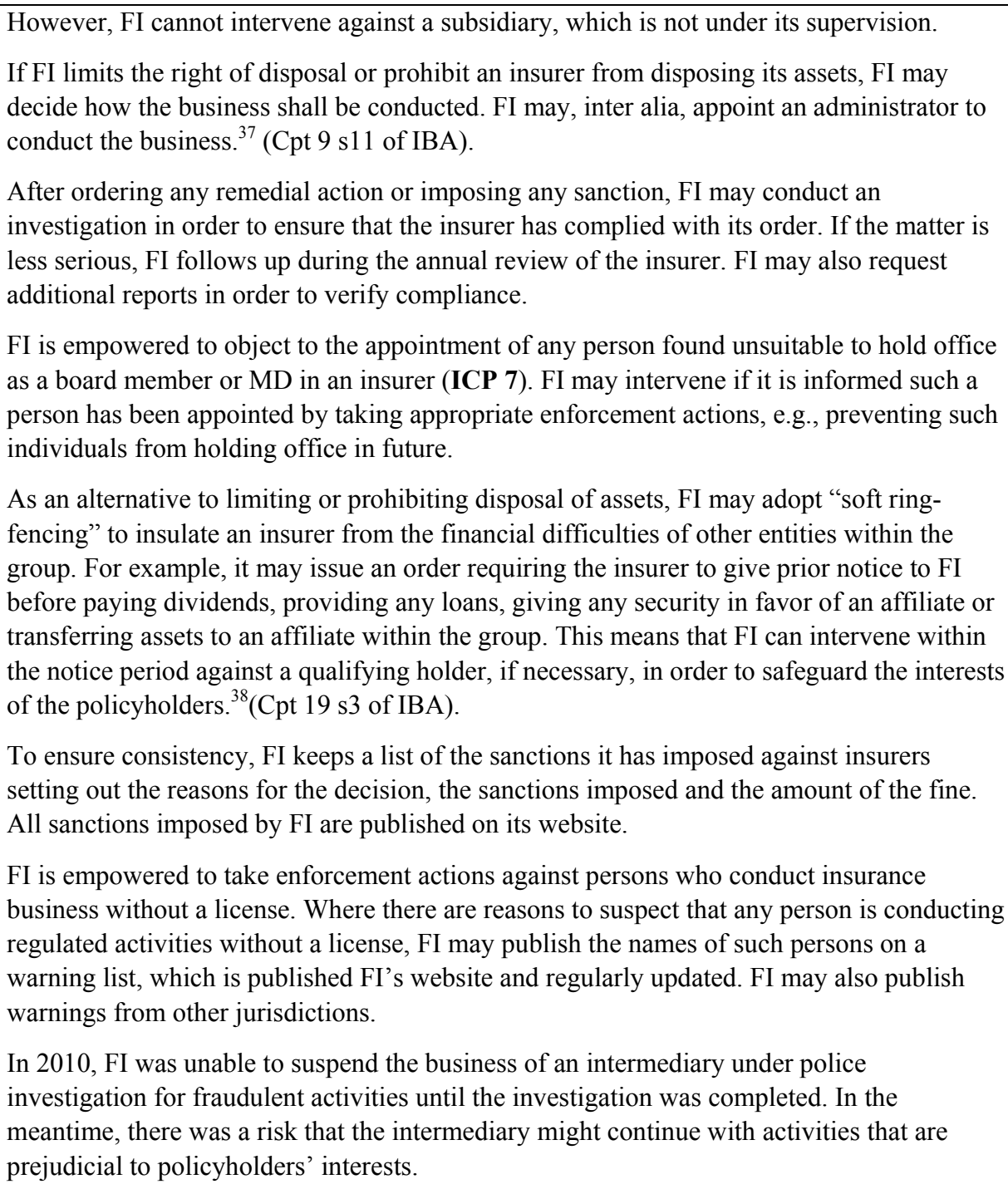 \\
\hline Assessment & Largely Observed \\
\hline Comments & $\begin{array}{l}\text { FI takes a proportionate approach in exercising its enforcement and sanction powers. } \\
\text { However, FI has no power to: a) order a compulsory transfer of insurance portfolios; } \\
\text { b) intervene against a subsidiary of an insurer who is not under its supervision; and c) take } \\
\text { measures to protect the interests of the public and policyholders pending the completion of } \\
\text { police investigations. } \\
\text { The authorities are advised to: } \\
\text { a) Empower FI to order a compulsory transfer of insurance portfolios of an insurer in } \\
\text { distress; }\end{array}$ \\
\hline
\end{tabular}

${ }^{37}$ FI revoked the licence of life insurer and appointed an administrator to conduct the business on behalf of FI until the court ordered the insurer to enter into compulsory liquidation.

${ }^{38}$ During the financial crisis in 2008 and 2009, FI ordered a number of insurers to give at least 48 hours' notice before carrying out any transaction involving the transfer of assets to their parent companies. 


\begin{tabular}{|c|c|}
\hline & $\begin{array}{l}\text { b) Strengthen FI's intervention powers against unregulated entities within an insurance } \\
\text { group or financial conglomerate; } \\
\text { c) Consider how best to empower FI in taking necessary measures to protect the interests } \\
\text { of the public pending the completion of police investigations; and } \\
\text { d) Review the government's continued involvement in enforcement and sanctions at } \\
\text { institution-specific level. }\end{array}$ \\
\hline Principle 16. & $\begin{array}{l}\text { Winding-up and exit from the market } \\
\text { The legal and regulatory framework defines a range of options for the orderly exit of } \\
\text { insurers from the marketplace. It defines insolvency and establishes the criteria and } \\
\text { procedure for dealing with insolvency. In the event of winding-up proceedings, the legal } \\
\text { framework gives priority to the protection of policyholders. }\end{array}$ \\
\hline Description & 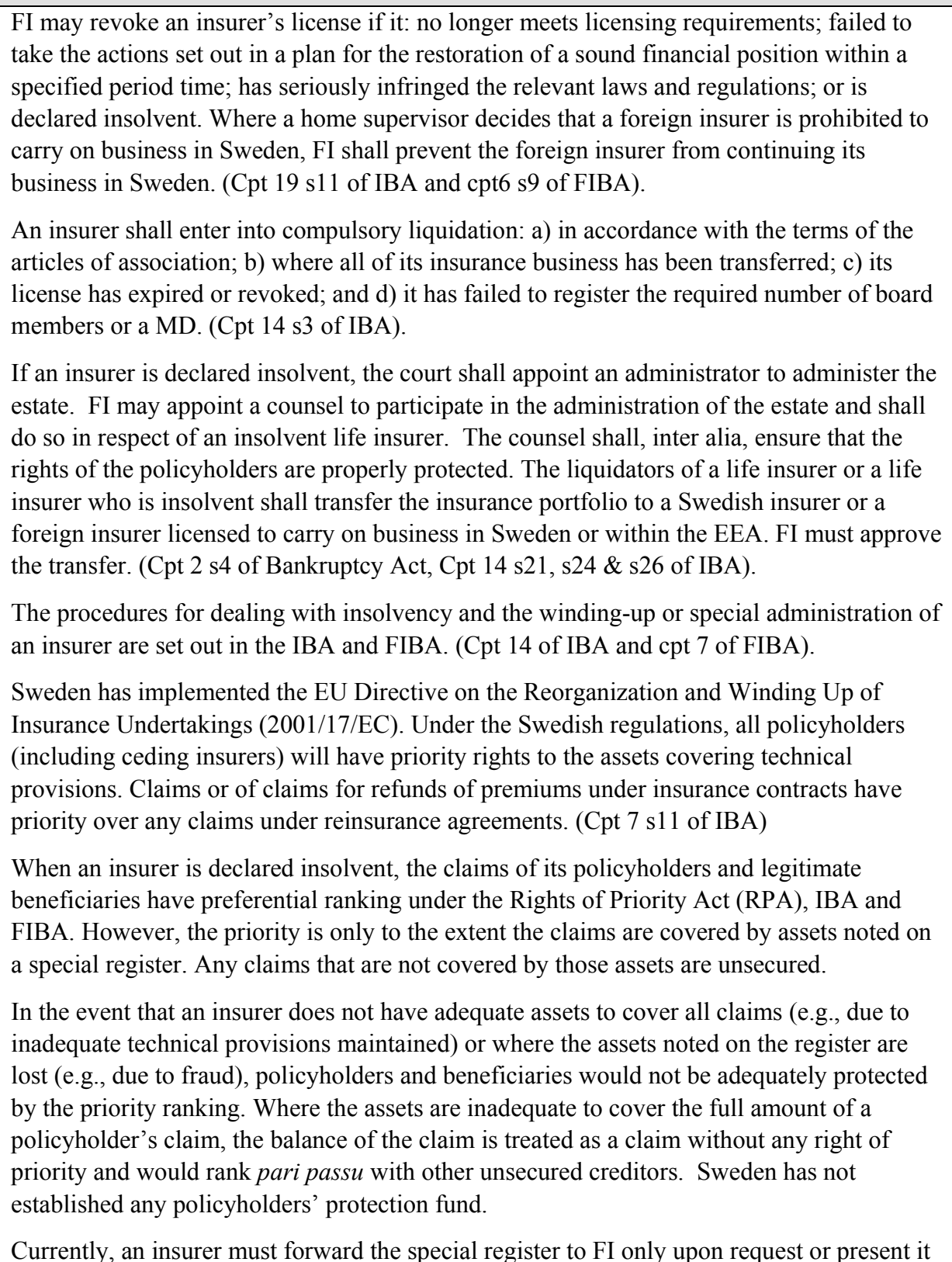 \\
\hline
\end{tabular}




\begin{tabular}{|c|c|}
\hline & $\begin{array}{l}\text { for FI's examination during inspections. Previously, insurers were under a duty to forward } \\
\text { the special register to FI annually but this requirement had been waived to reduce reporting } \\
\text { burden. Given a recent incident involving fraudulent use of assets covering technical } \\
\text { provision }{ }^{39} \text {,The authorities are advised to reconsider the waiver in this reporting } \\
\text { requirements (S4a of RPA, cpt } 7 \mathrm{~s} 11 \text {, cpt19s } 3 \text { of IBA, cpt } 5 \mathrm{~s} 11 \text { of FIBA and cpt } 8 \text { s5 of } \\
\text { FFFS2008:7). } \\
\text { Insurer shall not pledge any assets covering technical provisions. (Cpt7s10 of IBA). } \\
\text { The RPA, IBA ad FIBA does not set out any concrete principles for the rules that FI should } \\
\text { apply for dividing the existing assets to the policyholders in the event an insurer is } \\
\text { insolvent. It is up to the administrator or counsel appointed by FI to divide the available } \\
\text { assets of the estate to the creditors (including policyholders) in accordance with the priority } \\
\text { set out under the RPA. }\end{array}$ \\
\hline Assessment & Largely Observed \\
\hline Comments & $\begin{array}{l}\text { The IBA and FIBA provides for orderly exits of insurers from the market. Policyholders } \\
\text { (including ceding insurers) and legitimate beneficiaries have priority rights to the assets } \\
\text { covering insurers' technical provisions in the event of insolvency. Regulatory requirements } \\
\text { over assets covering technical provisions could be strengthened and clear rules of } \\
\text { distribution of assets in the event of insolvency should be established. } \\
\text { The authorities are advised to strengthen protection of policyholders and legitimate } \\
\text { beneficiaries by: } \\
\text { a) ensuring adequate controls over assets covering technical provisions including } \\
\text { quarterly submission of the special register of assets; and } \\
\text { b) establishing clear rules on how existing assets of an insolvent insurer are to be } \\
\text { distributed amongst policyholders. }\end{array}$ \\
\hline Principle 17. & $\begin{array}{l}\text { Group-wide supervision } \\
\text { The supervisory authority supervises its insurers on a solo and a group-wide basis. }\end{array}$ \\
\hline Description & $\begin{array}{l}\text { The IBA and SSFCA define what constitutes an insurance group and a conglomerate in } \\
\text { order to determine which groups are considered to be insurance groups or conglomerates; } \\
\text { and the scope of the supervision. (Cpt7a s1 \& s2 of IBA and cpt2 s1of SSFCA). } \\
\text { Supervisors within the EEA collaborate and coordinate the supervision of insurance group } \\
\text { pursuant to the Helsinki Protocol. While the Helsinki Protocol provides for closer co- } \\
\text { operation and co-ordination between supervisors, the supervision conducted by each home } \\
\text { supervisor remains unaffected. The Committee of European Insurance and Occupational } \\
\text { Pensions Supervisors (CEIOPS) have published guidelines for coordination committees as } \\
\text { a forum for cooperation on insurance supervisory matters. FI cooperates with foreign } \\
\text { supervisors and contributes to the coordination of supervision (Article } 5 \text { of the Instructions } \\
\text { to FI Order) } \\
\text { The Helsinki Protocol states that the supervisors should take into account possible } \\
\text { developments with regard to an insurer who is part of an insurance group and if necessary } \\
\text { adjust the supplementary supervision and cooperation. There are various platforms of } \\
\text { cooperation, e.g., through key-coordinator(s) or lead supervisor(s), depending on the group }\end{array}$ \\
\hline
\end{tabular}

${ }^{39}$ A Swedish life insurer had, inter alia, transferred a substantial sum of assets covering technical provision to a Swiss bank account of a third party, which was subsequently pledged as security in favour of the bank. There was a real risk that the assets might never be returned and that the registered assets would not be sufficient to cover all claims. FI and the liquidators, however, managed to arrange a portfolio transfer to another insurer. 




\footnotetext{
${ }^{40}$ Related party transactions to be reported include: items that may be included on own funds (e.g., subordinated loans), investments, loans, reinsurance and agreement for shared expenses.

${ }^{41}$ An undertaking within a conglomerate may not be exposed to financial risks or other risks which are large enough to threaten the solvency or the financial position of a regulated undertaking within the conglomerate. Material risk concentrations and including reinsurance risk concentrations shall, on an annual basis, be reported to FI. (Cpt 5 s7, s8 \&s11 of SSFCA and FFFS2006:6).
} 


\begin{tabular}{|c|c|}
\hline & $\begin{array}{l}\text { internal control systems }{ }^{42} \text { including reporting lines and fitness and propriety of board } \\
\text { members, MD and qualifying holder. } \\
\text { In the Traffic Light system, an insurer who is a parent company must take into account the } \\
\text { risks arising in subsidiaries whose core operations consist of owning or managing real } \\
\text { estate, equities, participating rights or other securities. These risks are to be included in } \\
\text { proportion to the insurer's percentage shareholding under the respective risks. } \\
\text { FI may reject an application for a license or revoke a license if the organizational (or group) } \\
\text { structure hinders effective supervision. } \\
\text { Sweden is the lead supervisor of five insurance groups for which supervisory colleges have } \\
\text { been established pursuant to the Helsinki Protocol }{ }^{43} \text { : Handels Liv Försäkringsaktiebolag, } \\
\text { IKANO, Nordea Life Holding AB, SEB Life and the former Skandia Group. } \\
\text { The large cross-border insurance groups submit risk management reports to FI, if Sweden } \\
\text { is the lead supervisor. These reports include large exposures and stress tests of the total } \\
\text { assets of the group. FI performed an assessment of concentration risks of one insurance } \\
\text { group in } 2010 \text {. FI, as the lead supervisor of another insurance group, worked together with } \\
\text { the other supervisors to formulate an annual risk assessment report for the group. }\end{array}$ \\
\hline Assessment & Largely Observed \\
\hline Comments & $\begin{array}{l}\text { Sweden's regulatory frameworks for insurance groups and conglomerates are in line with } \\
\text { current EU Directives. However, there are no specific provisions regarding: reinsurance, } \\
\text { risk concentrations, internal controls and risk management processes applicable to } \\
\text { insurance groups The impending implementation of Solvency II will strengthen supervision } \\
\text { of insurance groups, subject to the adequacy of regulatory resources. } \\
\text { The authorities are advised to consider: } \\
\text { a) reviewing the adequacy of supervisory resources, particularly for the effective } \\
\text { supervision of cross-border groups/conglomerates; } \\
\text { b) harmonizing the supervisory approach for insurance groups and conglomerates, e.g., in } \\
\text { the area of risk concentration; and } \\
\text { c) formulating appropriate regulatory requirements applicable to nonregulated holding } \\
\text { companies. }\end{array}$ \\
\hline \multicolumn{2}{|c|}{ Prudential Requirements } \\
\hline Principle 18. & $\begin{array}{l}\text { Risk assessment and management } \\
\text { The supervisory authority requires insurers to recognize the range of risks that they face } \\
\text { and to assess and manage them effectively. }\end{array}$ \\
\hline Description & FI has guidelines regarding governance and control. If the risk management system of an \\
\hline
\end{tabular}

${ }^{42}$ An insurer within a conglomerate shall adopt risk management processes and internal control mechanisms which are adequate having regard to the collective risk situation of the conglomerate. (Cpt 5 s13 of SSFCA).

${ }^{43}$ CEIOPS: List of groups for which a College of supervisors is in place.

${ }^{44}$ The group has been divided into three insurance groups (part of Old Mutual): Skandia Nordic, Skandia U.K. and Skandia Leben. There are ongoing discussions with concerned authorities due to the reorganization on the appropriate lead supervisor.

${ }^{45}$ Include non-operating holding companies, operating holding companies and non-regulated operating entities. 


\begin{tabular}{|c|c|}
\hline & $\begin{array}{l}\text { insurer deviates from the guidelines, it must justify to FI. (FFFS 2005:1). } \\
\text { However, FI has not developed any method to monitor the adequacy of insurers' risk } \\
\text { management systems on a regular basis. The submission of an annual risk management } \\
\text { report is still not mandatory. In practice, this information is available and analyzed as part } \\
\text { of supervision of major groups and undertakings. } \\
\text { FI also does not require an applicant for a license to submit any policies or procedures } \\
\text { regarding risk management and control. Insurers are also not under a duty to inform FI if its } \\
\text { policies and procedures depart from FI's guidelines. } \\
\text { During on-site inspection, FI would assess whether the risk management and control } \\
\text { systems are in place and adequate for the nature and scale of an insurer and may intervene } \\
\text { if it finds deficiencies. } \\
\text { Insurers are required to submit quarterly reports under the Traffic Light model (ICP 23). } \\
\text { However, certain risks, e.g., operational risks, are excluded from the Traffic Light model, } \\
\text { such as operational risks. In addition, the model would not take into account insurers' } \\
\text { internal models. } \\
\text { While systemic market risk, e.g., stock market crash would not lead to remedial action by } \\
\text { specific insurers, FI may work with insurers on an industry level to mitigate the potential } \\
\text { impact. FI requires insurers to take remedial action if a "red light" resulted from specific } \\
\text { risk, e.g., speculative investments. } \\
\text { While there is no specific provision regarding the establishment of board committees, } \\
\text { larger insurers typically establish a risk management function and some have set up risk } \\
\text { management committees. }\end{array}$ \\
\hline Assessment & Largely Observed \\
\hline Comments & $\begin{array}{l}\text { FI has issued guidelines on its supervisory expectation of insurers' risk management. There } \\
\text { is a lack of resources to implement policies and processes to monitor the adequacy of } \\
\text { insurers' risk management systems on a regular basis. } \\
\text { FI is advised to develop policies and processes to monitor the adequacy of insurers' risk } \\
\text { management systems on a regular basis including requiring insurers to report on their risk } \\
\text { management system as part of the annual returns. }\end{array}$ \\
\hline Principle 19. & $\begin{array}{l}\text { Insurance activity } \\
\text { Since insurance is a risk taking activity, the supervisory authority requires insurers to } \\
\text { evaluate and manage the risks that they underwrite, in particular through reinsurance, and } \\
\text { to have the tools to establish an adequate level of premiums. }\end{array}$ \\
\hline Description & $\begin{array}{l}\text { FI has issued guidelines on managing underwriting risks and reinsurance risks. The board } \\
\text { of an insurer shall adopt policies governing underwriting of insurance and reinsurance } \\
\text { business. The policy should provide for adequate spreading of risks and appropriate } \\
\text { composition of insurance portfolios, having regard to the financial condition of the insurer. } \\
\text { The board should also adopt a reinsurance program and minimize unforeseen risks. The } \\
\text { policies should be regularly reviewed and be kept up-to-date. (FFFS 2000:5). } \\
\text { The board should ensure that underwriting instructions and limits are complied with. } \\
\text { Underwriting limits, estimated maximum loss and retention limits are to be properly } \\
\text { documented. The underwriting instructions shall cover guidelines regarding risk } \\
\text { assessment, risk acceptance, determination of premiums and renewals. } \\
\text { A reinsurance program should include: a list of all reinsurance agreements in force; } \\
\text { principles for reinsurance cover within each insurance class or risk group; retention limits } \\
\text { within each insurance class or risk group; guidelines regarding choice of reinsurer; and }\end{array}$ \\
\hline
\end{tabular}




\begin{tabular}{|c|c|}
\hline & $\begin{array}{l}\text { guidelines for ceding reinsurance within the group. } \\
\text { During its on-site inspections, FI checks that insurers evaluate the risks based on sound } \\
\text { underwriting principles and establish and maintain an adequate level of premiums. FI also } \\
\text { examines whether insurers have systems in place to control their expenses related to } \\
\text { premiums and claims, including claims handling and administration expense } \\
\text { FI has no power to direct how insurers calculate premiums, but is authorized to review the } \\
\text { methodology used to set premium. FI may intervene if the technical provisions are deemed } \\
\text { to be too low. } \\
\text { At the beginning of each year, FI reviews ceded reinsurance by insurers with low retention } \\
\text { ratios. FI would assess whether the rating of the reinsurers are satisfactory and require } \\
\text { insurers to explain their reinsurance arrangements, if necessary. } \\
\text { FI may refuse deductions for reinsurance in an insurer's solvency computation if it is not } \\
\text { satisfied with the reinsurance security or where it involves financial reinsurance that does } \\
\text { not constitute a transfer of risks. However, there are no established criteria or threshold to } \\
\text { determine whether there is risk transfer. If the reinsurer is authorized in another EEA state, } \\
\text { deduction may not be denied based on deficiencies in the financial soundness of the } \\
\text { (re)insurer." (Cpt } 7 \text { s } 23 \text { \& s } 25 \text { of IBA, Cpt7 s9 of IBA). } \\
\text { FI has not implemented any specific procedures to check that risk transfer instruments are } \\
\text { properly accounted for in the annual reports of insurers. FI relies on auditors who audited } \\
\text { the annual reports and may check this during on-site inspection. }\end{array}$ \\
\hline Assessment & Largely Observed \\
\hline Comments & $\begin{array}{l}\text { FI has issued guidelines on managing underwriting risks and reinsurance risks. It reviews } \\
\text { insurers' underwriting policies and controls as well as reinsurance arrangements during on- } \\
\text { site inspections. Supervisory processes in relation to assessment of insurers' reinsurance } \\
\text { arrangements and risk transfer instruments could be enhanced. } \\
\text { FI is advised to: } \\
\text { a) review the adequacy of reinsurance programs as part of its routine off-site surveillance } \\
\text { instead of the current limited scope review; and } \\
\text { b) establish policies and procedures to check that insurers properly account for all risk } \\
\text { transfer instruments. }\end{array}$ \\
\hline Principle 20. & $\begin{array}{l}\text { Liabilities } \\
\text { The supervisory authority requires insurers to comply with standards for establishing } \\
\text { adequate technical provisions and other liabilities, and making allowance for reinsurance } \\
\text { recoverables. The supervisory authority has both the authority and the ability to assess the } \\
\text { adequacy of the technical provisions and to require that these provisions be increased, if } \\
\text { necessary. }\end{array}$ \\
\hline Description & $\begin{array}{l}\text { Technical provisions of an insurer shall correspond to the sum required to meet its } \\
\text { commitments that may be reasonably expected to arise from time to time. IBA also sets out } \\
\text { the principles and methodology for establishing and calculating technical provisions. (Cpt } 7 \\
\text { s1 to s4 of IBA and cpt } 4 \text { s9 of ARIUA). } \\
\text { FI has issued guidelines on technical provisions guidelines and basis for actuarial } \\
\text { calculations and regulations on insurers' choice of interest rate for calculation of technical } \\
\text { provisions. (FFFS 2003:8 and FFFS2008:23). } \\
\text { To address the volatility and procyclical effects of using current market interest rates as the } \\
\text { discount rate for technical provision, FI is proposing the use of a "calculated long-term }\end{array}$ \\
\hline
\end{tabular}




\begin{tabular}{|c|c|}
\hline & 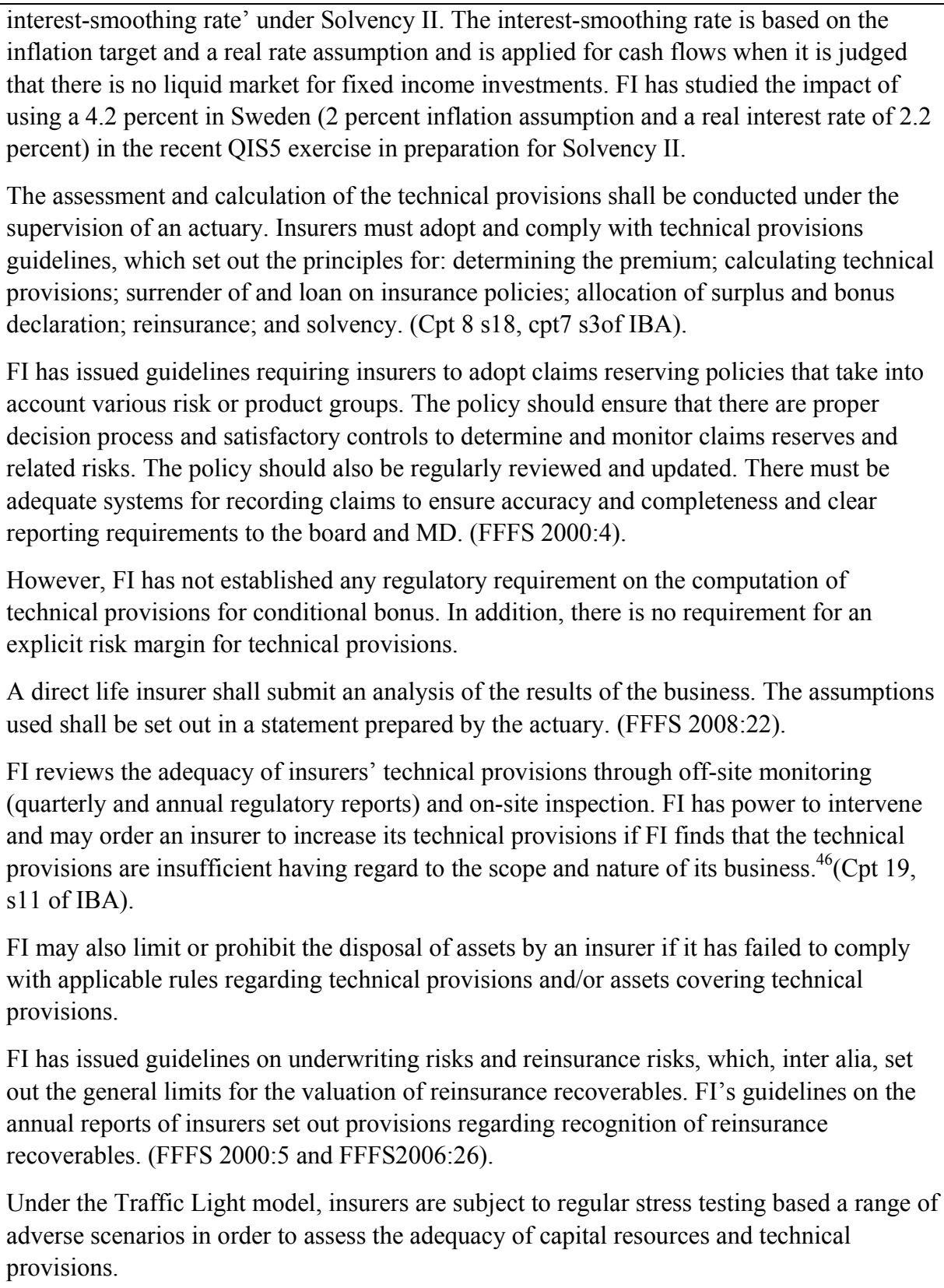 \\
\hline Assessment & Largely Observed \\
\hline Comments & $\begin{array}{l}\text { FI has established principles and regulatory guidelines on the computation of insurers' } \\
\text { technical provisions, which are subject to stress testing under the Traffic Light Model. FI is } \\
\text { empowered to require insurers to remedy any shortfall in their technical provisions, if } \\
\text { necessary. However, there is no explicit risk margin and no regulatory policy for } \\
\text { computing technical provisions in respect of conditional bonuses. }\end{array}$ \\
\hline
\end{tabular}

${ }^{46}$ Traffic Light results of a non-life insurer suggested that its technical provisions were insufficient. FI conducted informal discussions with the insurer, who then injected capital and increased the technical provisions. The insurer was subsequently sold to another insurer. 


\begin{tabular}{|c|c|}
\hline & $\begin{array}{l}\text { The implementation of Solvency II will strengthen FI's supervision over insurers' technical } \\
\text { provisions. }\end{array}$ \\
\hline Principle 21. & $\begin{array}{l}\text { Investments } \\
\text { The supervisory authority requires insurers to comply with standards on investment } \\
\text { activities. These standards include requirements on investment policy, asset mix, valuation, } \\
\text { diversification, asset-liability matching, and risk management. }\end{array}$ \\
\hline Description &  \\
\hline
\end{tabular}




\begin{tabular}{|c|c|}
\hline & $\begin{array}{l}\text { investment operations. In auditing the annual report of an insurer, the external auditor } \\
\text { would include an assessment of its investment activities. (Cpt } 6 \text { s1 of FFFS 2005:1). } \\
\text { At the time of assessment, there were no explicit regulatory requirements on: } \\
\text { a) the level of skills, experience and integrity of the staff involved in investment } \\
\text { activities; } \\
\text { b) asset-liability management; }{ }^{47} \text { and } \\
\text { c) contingency plans to mitigate the effects of deteriorating conditions. } \\
\text { The new IBL effective on April } 1,2011 \text { addresses the above issues. } \\
\text { During } 2009 \text {, FI reviewed the registers of assets covering technical provisions maintained } \\
\text { by insurers. FI found insurers' handling of the register to be unsatisfactory. }\end{array}$ \\
\hline Assessment & Largely Observed \\
\hline Comments & $\begin{array}{l}\text { The IBA and FI regulations set out the requirements for insurers' investments covering } \\
\text { technical provisions. There is scope for updating FI's regulations to reflect international } \\
\text { best practice. FI does not have adequate resources to examine insurers' investment } \\
\text { operations on a regular basis. } \\
\text { FI is advised to enhance he robustness of its supervision of insurers' investment operations } \\
\text { and update its regulations on investment management by insurers. }\end{array}$ \\
\hline Principle 22. & $\begin{array}{l}\text { Derivatives and similar commitments } \\
\text { The supervisory authority requires insurers to comply with standards on the use of } \\
\text { derivatives and similar commitments. These standards address restrictions in their use and } \\
\text { disclosure requirements, as well as internal controls and monitoring of the related positions. }\end{array}$ \\
\hline Description & $\begin{array}{l}\text { Insurers may use options and forward contracts and other similar financial instruments to } \\
\text { reduce the financial risk and achieve efficient portfolio management. (Cpt7 s17b of IBA). } \\
\text { The disclosure requirements and valuation basis in respect of derivatives are set out in the } \\
\text { ARA, ARIUA and guidelines issued by FI. Insurers shall apply IFRS } 7 \text { (Financial } \\
\text { Instruments: Disclosures) in their financial statements to all financial instruments including } \\
\text { derivatives. If an insurer uses derivatives to reduce the insurance risk, it shall disclose } \\
\text { information according to IFRS } 4 \text { (Insurance Contract). Information regarding derivatives } \\
\text { shall be reported together with underlying assets. (Cpt } 5 \text { s1 of ARIUA, cpt } 5 \mathrm{~s} 3 \text { \& s4a to } \\
\text { s4c of ARA and FFFS 2008:26). } \\
\text { FI is in the process of formulating the regulations, which would address, inter alia, the } \\
\text { following elements currently not provided for under its guidelines: } \\
\text { a) provisions regarding required expertise, qualifications or competence related to the use } \\
\text { of derivatives; } \\
\text { b) content of the investment policy relevant to derivatives; } \\
\text { c) risk management requirement covering the risks from derivatives activities so insurers } \\
\text { can monitor and manage in an integrated manner with similar risks arising from } \\
\text { nonderivatives activities on a consolidated basis; }\end{array}$ \\
\hline
\end{tabular}

47 The practice of managing a business so that decisions and actions taken with respect to assets and liabilities are coordinated

${ }^{48}$ FI's Supervisory Report for 2010. 


\begin{tabular}{|c|c|}
\hline & $\begin{array}{l}\text { d) internal controls over derivatives; } \\
\text { e) measures for ensuring that staff have appropriate skills to vet models and price the } \\
\text { instruments; } \\
\text { f) policy on the use of "over-the-counter" derivatives; and } \\
\text { g) internal audit procedures covering derivatives activities. }\end{array}$ \\
\hline Assessment & Partly Observed \\
\hline Comments & $\begin{array}{l}\text { Insurers disclose their derivative activities in accordance with relevant accounting } \\
\text { standards, ARA and ARIUA. However, FI has not issued regulations on insurers' } \\
\text { derivative activities. It is in the process of drafting the regulations; as it is authorized do so } \\
\text { under the new IBA. } \\
\text { The authorities are advised to expedite the issuance of regulations governing insurers' } \\
\text { derivative activities. }\end{array}$ \\
\hline Principle 23. & $\begin{array}{l}\text { Capital adequacy and solvency } \\
\text { The supervisory authority requires insurers to comply with the prescribed solvency regime. } \\
\text { This regime includes capital adequacy requirements and requires suitable forms of capital } \\
\text { that enable the insurer to absorb significant unforeseen losses. }\end{array}$ \\
\hline Description & 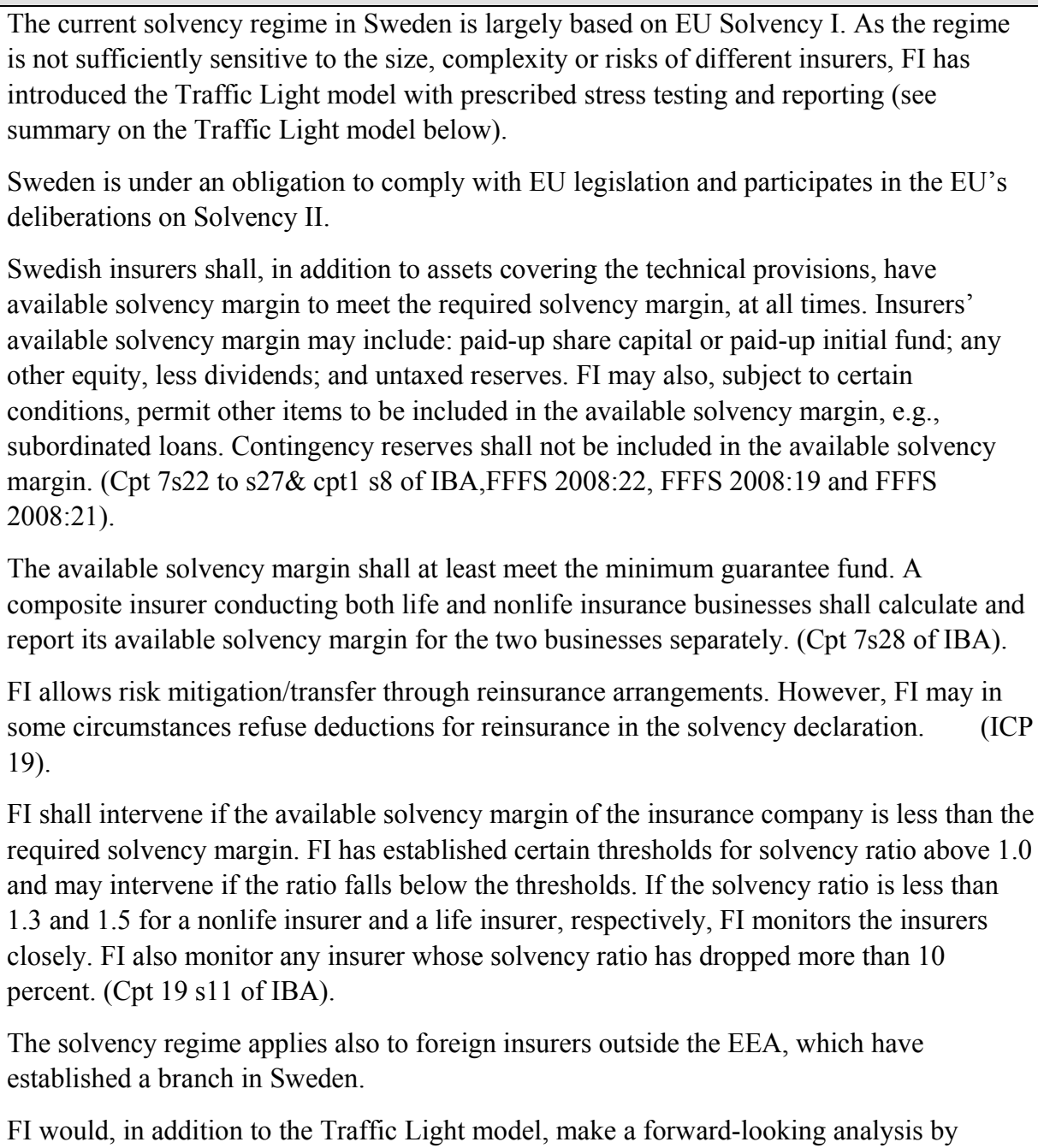 \\
\hline
\end{tabular}




\begin{tabular}{|c|c|}
\hline & 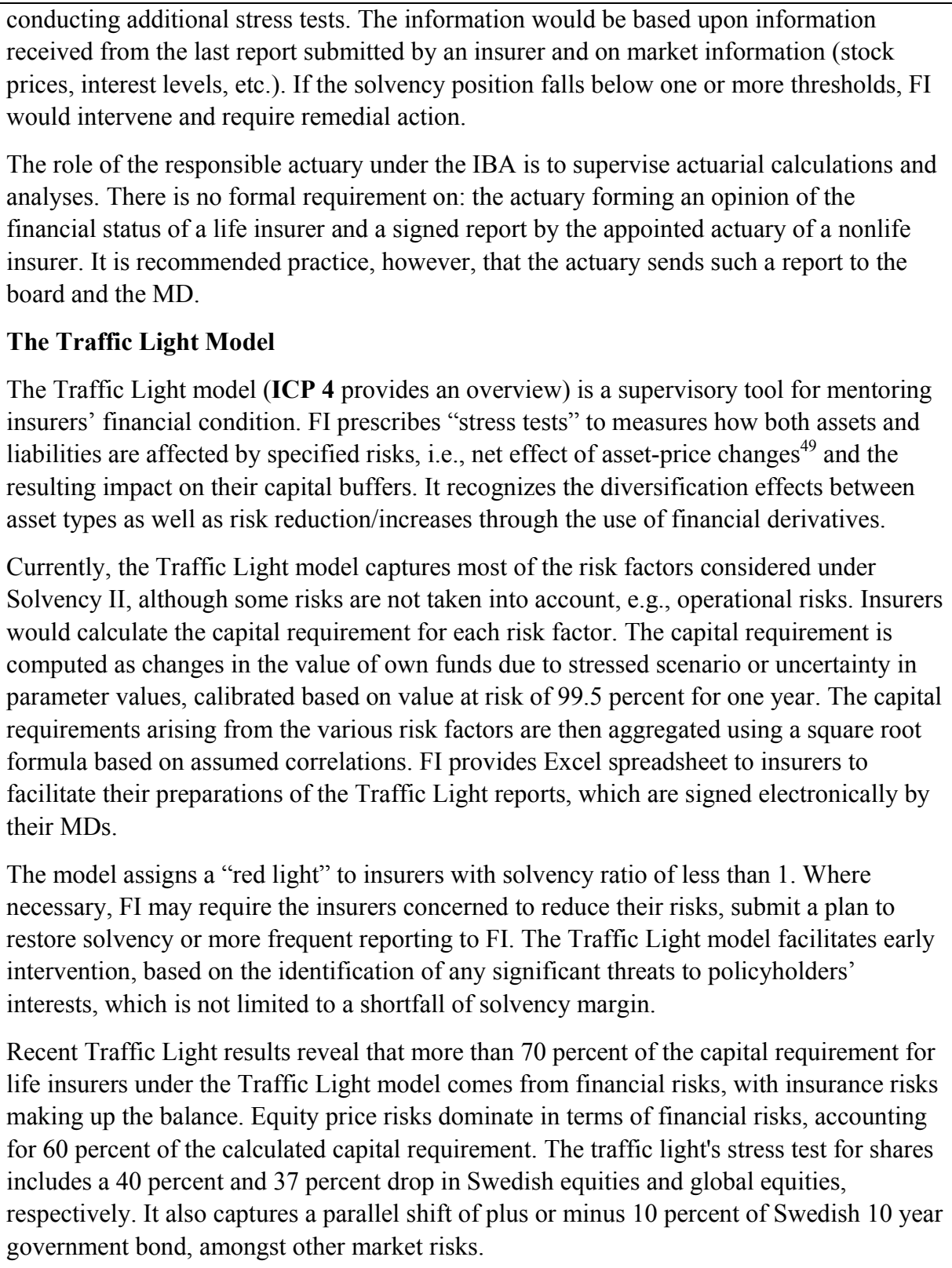 \\
\hline Assessment & Largely Observed \\
\hline Comments & $\begin{array}{l}\text { The current solvency regime in Sweden is largely based on EU Solvency I. As the regime } \\
\text { does not take account of all key risks of insurers, FI has introduced the Traffic Light model } \\
\text { with prescribed stress testing and reporting requirements as a supervisory tool to better } \\
\text { understand insurers' risks profiles and to facilitate early intervention, where appropriate. } \\
\text { The implementation of Solvency II with effect from January } 2013 \text { will facilitate FI in }\end{array}$ \\
\hline
\end{tabular}

${ }^{49}$ Example: A decline in equity prices normally only affects assets in the balance sheet. However, if the insurer has a conditional bonus in its actuarial provisions that depends on the value of its shareholdings, the change in actuarial provisions resulting from the decline in the share price must be included. The same applies to all asset-price changes that affect both assets and liabilities. 


\begin{tabular}{|c|c|}
\hline & implementing a more robust and risk-sensitive solvency regime. \\
\hline \multicolumn{2}{|c|}{ Markets and consumers } \\
\hline Principle 24. & $\begin{array}{l}\text { Intermediaries } \\
\text { The supervisory authority sets requirements, directly or through the supervision of insurers, } \\
\text { for the conduct of intermediaries. }\end{array}$ \\
\hline Description & 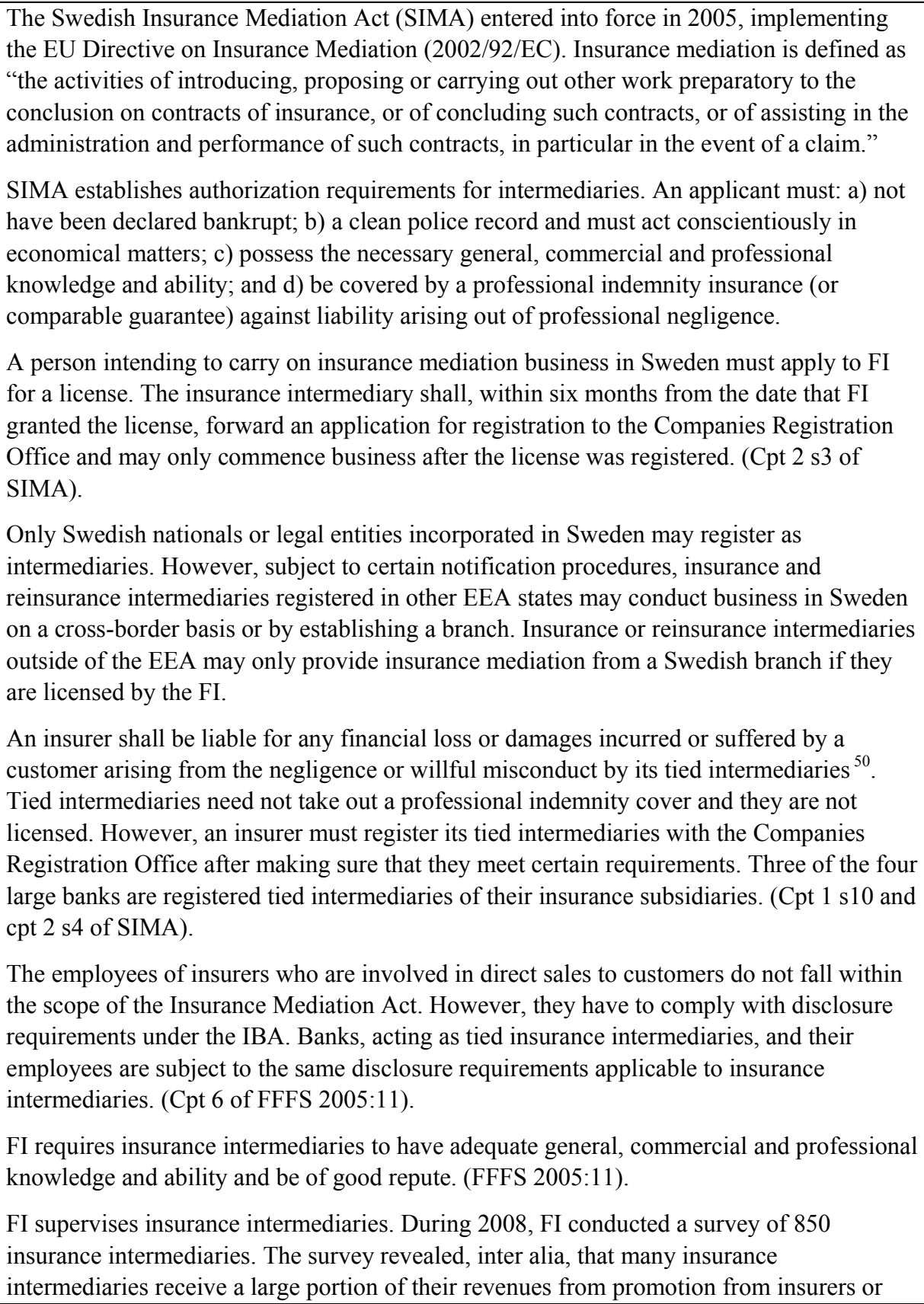 \\
\hline
\end{tabular}

${ }^{50}$ A tied intermediary is defined as a natural or legal person who has entered into an agreement with one or several insurers regarding the mediation of insurance products. 


\begin{tabular}{|c|c|}
\hline & $\begin{array}{l}\text { investment firms, which may pose conflict of interests and affect their obligations to act in } \\
\text { the best interests of their clients. As a result of the survey, FI issued } 30 \text { sanctions ranging } \\
\text { from warnings with fines, to injunctions and reprimands. FI also concluded that it is } \\
\text { important to have clear distinction between marketing and mediation (see ICP 25). (Cpt } 7 \\
\text { s1\& s4 of SIMA and FI Report 2009-04-07). } \\
\text { Due to limited supervisory resources, there were very few inspections of banks in their role } \\
\text { as tied intermediaries in } 2009 \text { and } 2010 \text {. } \\
\text { FI has sanctioned a number of insurance intermediaries in the past } 3 \text { years. In particular, FI } \\
\text { sanctioned a tied insurance intermediary in } 2008 \text {, by issuing a warning and imposing a fine } \\
\text { of SEK } 800,000 \text { for regulatory breaches. (Cpt } 7 \text { s3 of SIMA). } \\
\text { FI may intervene if an insurance intermediary has failed to perform its duties under the law. } \\
\text { FI may order the insurance intermediary to take remedial action or issue an injunction or a } \\
\text { reprimand. If the infringement is serious, FI may revoke the license of the insurance } \\
\text { intermediary or the registration of a tied intermediary or issue a warning. }{ }^{51} \text { (Cpt } 8 \text { s1of } \\
\text { SIMA). } \\
\text { An insurance intermediary who handles client's money or assets must keep them separate } \\
\text { from his or her own assets. The intermediary must open a separate account designated as } \\
\text { "clients account." Assets held in the clients account must be properly segregated. The } \\
\text { Client Accounts Act provides that the assets of a client would be protected from the } \\
\text { insolvency or bankruptcy of an intermediary if the assets were kept in a separate account. } \\
\text { (Cpt } 5 \text { s5of SIMA). } \\
\text { An insurance intermediary shall provide its/his name and address and information } \\
\text { regarding the relevant registry where its/his details are recorded. An insurance intermediary } \\
\text { shall, before the execution of an insurance contract, inform the customer whether it/he is } \\
\text { under a contractual obligation to mediate insurance products of one or more insurance } \\
\text { undertakings and provide the name(s). (Cpt } 6 \text { s1 \& s } 2 \text { of SIMA). } \\
\text { fine if it fails to do so. (Cpt } 8 \text { s } 19 \text { \&s } 20 \text { of SIMA). } \\
\text { license to discontinue with the business. The person may be liable to pay an administrative }\end{array}$ \\
\hline Assessment & Observed \\
\hline Comments & $\begin{array}{l}\text { FI administers the licensing of intermediaries with established criteria and monitors } \\
\text { intermediaries' compliance with applicable regulatory requirements. }\end{array}$ \\
\hline Principle 25. & $\begin{array}{l}\text { Consumer protection } \\
\text { The supervisory authority sets minimum requirements for insurers and intermediaries in } \\
\text { dealing with consumers in its jurisdiction, including foreign insurers selling products on a } \\
\text { cross-border basis. The requirements include provision of timely, complete and relevant } \\
\text { information to consumers both before a contract is entered into through to the point at } \\
\text { which all obligations under a contract have been satisfied. }\end{array}$ \\
\hline Description & $\begin{array}{l}\text { The responsibility for consumer protection is divided between FI and the SCA, with the } \\
\text { involvement of other government agencies. FI acts on the basis of financial sector } \\
\text { legislations and regulations, while the SCA administers the Swedish marketing Act and the }\end{array}$ \\
\hline
\end{tabular}

${ }^{51}$ FI issued a warning against a tied intermediary and imposed a fine of SEK 800,000 for failing to comply with obligations under the SIMA and FFFS 2005:11. The intermediary did not meet the requirements regarding knowledge and experience, the business was not carried on in accordance with good insurance mediation practice and it had failed to adopt customer complaints procedures. 


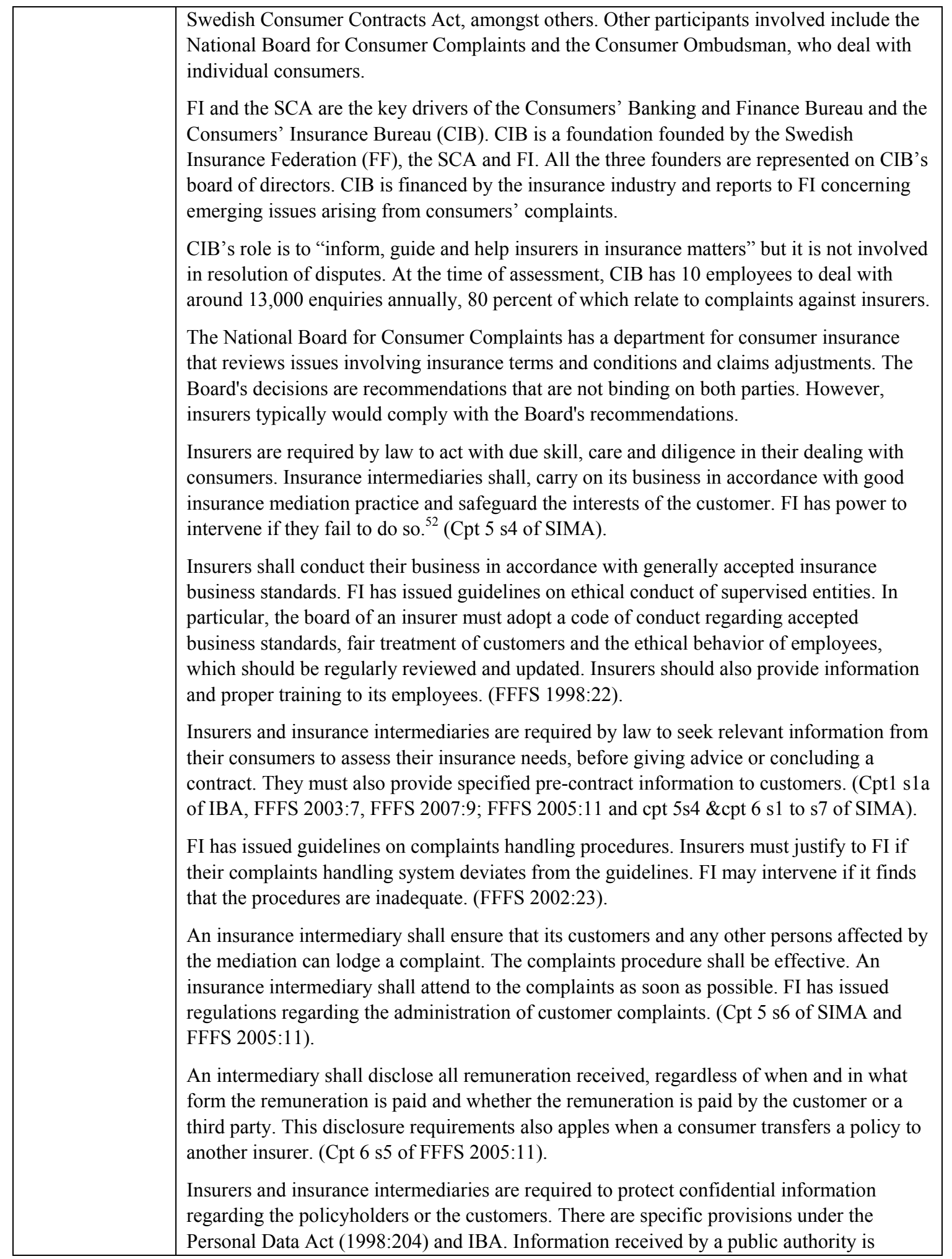

${ }^{52}$ FI found that an insurance intermediary had failed to act in accordance with good insurance mediation practice and imposed a fine in the sum of SEK 700,000. 


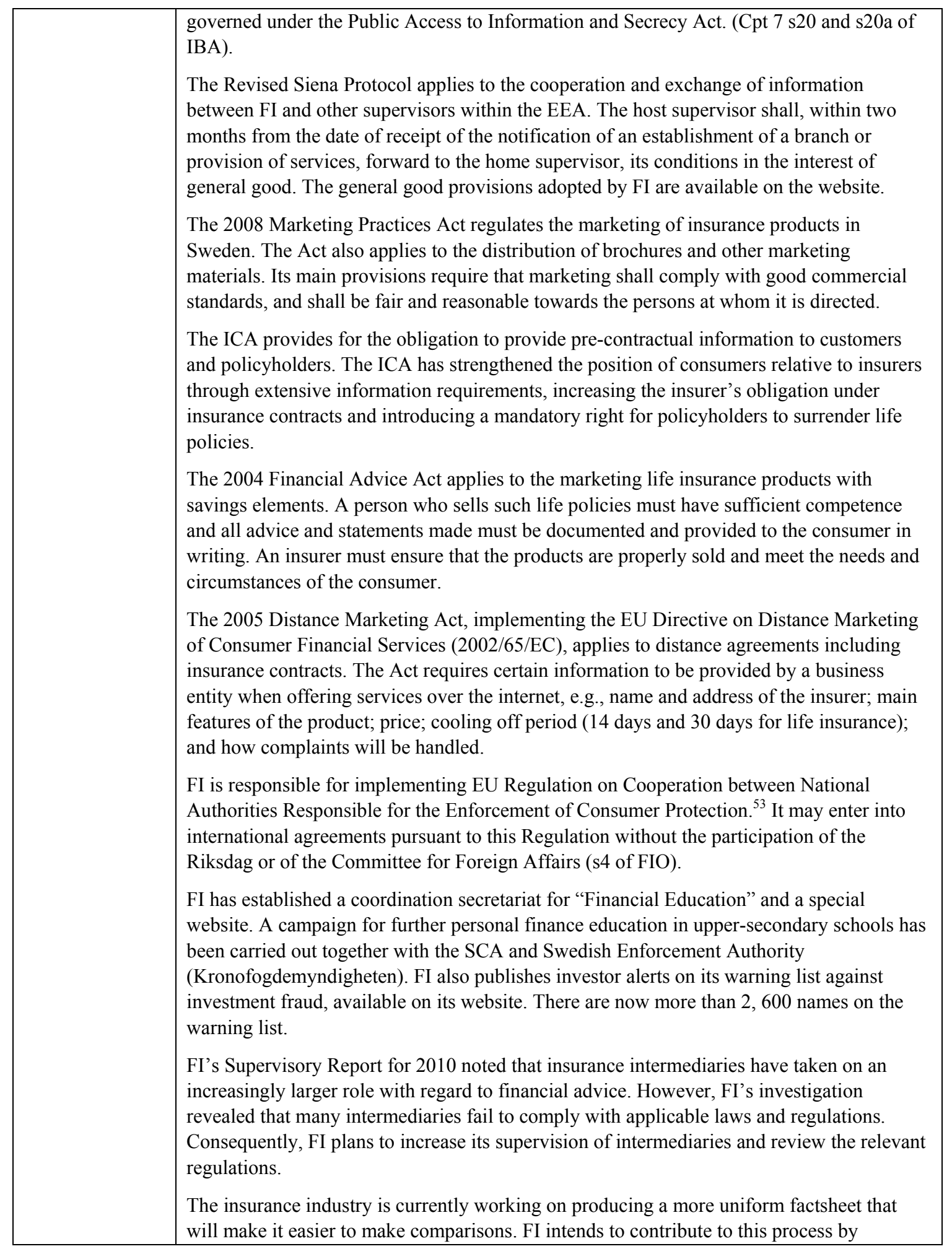

${ }^{53}$ Regulation (EC) No. 2006/2004 of the European Parliament and of the Council dated October 27, 2004. 


\begin{tabular}{|c|c|}
\hline & $\begin{array}{l}\text { publishing general guidelines setting out what the factsheets should contain. } \\
\text { Some life policies provide for conditional bonuses that are not guaranteed but would vary } \\
\text { according to the investment performance of the underlying assets. FI has not issued } \\
\text { guidelines on how insurers are expected to exercise their discretion in deciding on the level } \\
\text { of conditional bonus and the related disclosures to policyholders. Historically, the principle } \\
\text { and basis for sharing surpluses between shareholders and policyholders is not a significant } \\
\text { issue in Sweden as most insurers were structured as mutual societies. However, as insurers } \\
\text { are increasingly incorporated as companies, there is scope for the authorities to formulate } \\
\text { regulatory requirements to achieve equity between policyholders and shareholders as well } \\
\text { as equity between different classes or generations of policyholders. } \\
\text { Insurers expressed concerns on the increasing incidence of policyholders transferring their } \\
\text { policies without proper advice on whether such transfers are in their best interests. It is } \\
\text { recognized that most transfers of traditional policies are likely to result in lower benefits to } \\
\text { policyholders due the reduced assumed yield rates over the years. The authorities are } \\
\text { advised to review whether existing regulatory measures are adequate to ensure that } \\
\text { policyholders are given proper advice in their best interests in respect of policy transfers. }\end{array}$ \\
\hline Assessment & Largely Observed \\
\hline Comments & $\begin{array}{l}\text { The regime for consumer protection in Sweden is established under various legislations, } \\
\text { administered mainly by FI and SCA with the support of industry associations. Other } \\
\text { agencies involved include the National Board for Consumer Complaints and the Consumer } \\
\text { Ombudsman. Consumer protection should be strengthened by establishing regulatory } \\
\text { requirements for conditional bonuses and review of effectiveness of regulatory measures } \\
\text { for transfer of policies. } \\
\text { The authorities are advised to: } \\
\text { a) review the adequacy of current regulatory requirements for conditional bonus and } \\
\text { transfer of policies; and } \\
\text { b) consider articulating more clearly the roles and accountabilities of various agencies } \\
\text { involved in consumer protection to improve efficiency and promote better } \\
\text { understanding by consumers. }\end{array}$ \\
\hline Principle 26. & $\begin{array}{l}\text { Information, disclosure \& transparency towards the market } \\
\text { The supervisory authority requires insurers to disclose relevant information on a timely } \\
\text { basis in order to give stakeholders a clear view of their business activities and financial } \\
\text { position and to facilitate the understanding of the risks to which they are exposed. }\end{array}$ \\
\hline Description & $\begin{array}{l}\text { Insurers are required to disclose information to stakeholders in their annual reports, } \\
\text { prepared in accordance with the provisions set out in the ARIUA, ARA as well as } \\
\text { regulations and guidelines issued by FI. There are also additional disclosure requirements } \\
\text { for listed insurers. } \\
\text { Specifically, insurers are required to provide in the directors' report: } \\
\text { - technical results for the last five financial years; and a key figure with reference to } \\
\text { capital strength at the end of the last five financial years. (Cpt } 6 \text { s } 2 \text { of ARIUA); } \\
\text { - technical provisions; the proportion of reinsurer's part of technical provisions; and } \\
\text { income, costs and the result of the business operations. (Cpt } 6 \text { s3 of ARIUA); } \\
\text { information regarding the use of financial instruments including objectives and } \\
\text { principles applied for financial risk management; the principles for hedging for which } \\
\text { hedge accounting is used; and exposure for price risks, credit risks, liquidity risks and } \\
\text { cash flow risks. (Cpt } 6 \mathrm{~s} 1 \text { of ARIUA); and }\end{array}$ \\
\hline
\end{tabular}




\begin{tabular}{|c|c|}
\hline & $\begin{array}{l}\text { Management and corporate governance. (Cpt } 6 \text { s1 of ARIUA). } \\
\text { Insurers shall file, at the Companies Registration Office, certified copies of the annual } \\
\text { report and the auditors' report in respect of the previous financial year within one month } \\
\text { following their approval. The annual report and the auditor's report are available to the } \\
\text { general public. (Cpt } 8 \mathrm{~s} 5 \text { of ARA). }\end{array}$ \\
\hline Assessment & Largely Observed \\
\hline Comments & $\begin{array}{l}\text { The ARIUA, ARA as well as regulations and guidelines issued by FI governs insurers' } \\
\text { public disclosure. However, the disclosures do not fully cover the requirements under the } \\
\text { IAIS standards on public disclosure. } \\
\text { To facilitate market discipline, FI should formulate plans to implement the IAIS } \\
\text { supervisory standards on public disclosures. }\end{array}$ \\
\hline Principle 27. & $\begin{array}{l}\text { Fraud } \\
\text { The supervisory authority requires that insurers and intermediaries take the necessary } \\
\text { measures to prevent, detect and remedy insurance fraud. }\end{array}$ \\
\hline Description & $\begin{array}{l}\text { Under the current organizational structure in Sweden on combating economic/financial } \\
\text { crimes, FI does not have the formal authority to establish and enforce regulations to combat } \\
\text { fraud. The SECA is responsible for coordination measures against economic crime. SECA } \\
\text { investigates false accounting, crime relating to bankruptcy, tax crimes, insider dealing, EU } \\
\text { fraud and other complex economic crime that requires financial and business expertise. FI } \\
\text { communicates with enforcement authorities as well as with other supervisors to deter, } \\
\text { detect, and record, but not to remedy fraud in insurance. } \\
\text { Fraud is generally addressed in the Criminal Code, which covers insurance fraud, e.g., } \\
\text { where an insured person deliberately causes him/herself injury in order to claim insurance } \\
\text { compensation. Claims fraud is a punishable offence. } \\
\text { FI does not have the legal obligation to require insurers to report fraud to appropriate } \\
\text { authorities. FI has, however, issued nonbinding regulations and insurers are expected to } \\
\text { report events that may jeopardize its stability or policyholders' assets. SECA exchanges } \\
\text { information with FI including suspected cases of instance fraud. } \\
\text { During its inspections, FI staff regularly raises the question of counter-fraud measures. This } \\
\text { may include underwriting process or independent reviews of sampled closed claims files. } \\
\text { The Swedish Insurance Federation has on its own initiative, organized counter-fraud } \\
\text { activities. The industry has also organized a common claims database. } \\
\text { FI recently cooperated with other supervisors to investigate the Aspis Liv } \\
\text { Försäkringsaktiebolag case, where cooperation took place with supervisory authorities in } \\
\text { Greece, Portugal and U.K. }\end{array}$ \\
\hline Assessment & Observed \\
\hline Comments & $\begin{array}{l}\text { FI and industry participants have taken a proactive approach to combating insurance fraud. } \\
\text { There is also close cooperation and information exchange with SECA and other }\end{array}$ \\
\hline
\end{tabular}

\footnotetext{
${ }^{54}$ Standard on Disclosures Concerning Technical Performance and Risks for Nonlife Insurers and Reinsurers (October 2004), Standard on Disclosures Concerning Investment Risks and Performance for Insurers and Reinsurers (October 2005) and Standard on Disclosures concerning Technical Risks and Performance for Life Insurers (October 2006).
} 


\begin{tabular}{|c|c|}
\hline & $\begin{array}{l}\text { enforcement agencies and other supervisors, both locally and internationally, to address } \\
\text { fraud to preserve the integrity of the insurance sector. }\end{array}$ \\
\hline \multicolumn{2}{|c|}{ Anti-money laundering, combating the financing of terrorism } \\
\hline Principle 28. & $\begin{array}{l}\text { Anti-money laundering/combating the financing of terrorism } \\
\text { The supervisory authority requires insurers and intermediaries, at a minimum those insurers } \\
\text { and intermediaries offering life insurance products or other investment related insurance, to } \\
\text { take effective measures to deter, detect and report money laundering and the financing of } \\
\text { terrorism consistent with the Recommendations of the Financial Action Task Force (FATF) } \\
\text { on Money Laundering. }\end{array}$ \\
\hline Description & $\begin{array}{l}\text { Sweden was evaluated by FATF in } 2006 \text { and was placed into regular follow-up. Since then, } \\
\text { Sweden has been taking action to enhance its AML/CFT regime in line with the } \\
\text { recommendations in the FATF Mutual Evaluation Report. }{ }^{55} \text { FATF has noted that Sweden } \\
\text { has taken measures to bring } 18 \text { out of the } 20 \text { recommendations previously rated partially } \\
\text { compliant or noncompliant to at least a level equivalent to largely compliant. In recognition } \\
\text { of the progress made, the FATF plenary has agreed to take Sweden out of the regular } \\
\text { follow-up process. } \\
\text { In } 2009 \text {, Sweden adopted a new legislation to counteract money laundering and terrorism } \\
\text { financing, namely the Act on Measures against Money Laundering and Terrorist Financing } \\
\text { (SFS } 2009 \text { :62) (AML/CFT Act). The AML/CFT Act implements EU Directive 2005/60/EC } \\
\text { and the accompanying Commission Directive } 2006 / 70 / E C \text {, which give effect to the FATF } \\
\text { 40 + } 9 \text { recommendations. } \\
\text { The AML/CFT Act is applicable to life insurance businesses and insurance mediation. FI } \\
\text { has been mandated to set up a coordinating body for AML/CFT supervisory authorities, } \\
\text { supervising both financial entities and nonfinancial entities. In particular, FI is responsible } \\
\text { for supervising life insurers' and insurance intermediaries' compliance with the AML-CFT } \\
\text { Act. FI has issued regulations on Measures against Money Laundering and Terrorist } \\
\text { Financing. (Cpt1 s2 and cpt } 6 \text { s1 \& s2 of AML-CFT Act and FFFS 2009:1) } \\
\text { The AML-CFT Act and FFFS } 2009: 1 \text { requires insurers and insurance intermediaries to } \\
\text { comply with AML/CFT requirements which are consistent with the FATF } \\
\text { Recommendations, including: } \\
\text { - designating a Money Laundering Reporting Officer; } \\
\text { FI has established a special unit in its Markets Supervision department, with } 8 \text { staff } \\
\text { members to support the other departments on AML/CFT issues. The unit also conducts } \\
\text { and terrorist financing including policies and procedures for CDD, i.e., normal CDD, } \\
\text { simplified CDD and enhanced CDD), record retention, detection of unusual and } \\
\text { suspicious transactions and reporting, staff training, as well as protection against threats } \\
\text { towards staff; }\end{array}$ \\
\hline
\end{tabular}

${ }^{55}$ Fourth Follow-up Report on Sweden, October 2010: http://www.fatf-gafi.org/dataoecd/58/30/46253171.pdf 


\begin{tabular}{|c|c|}
\hline & 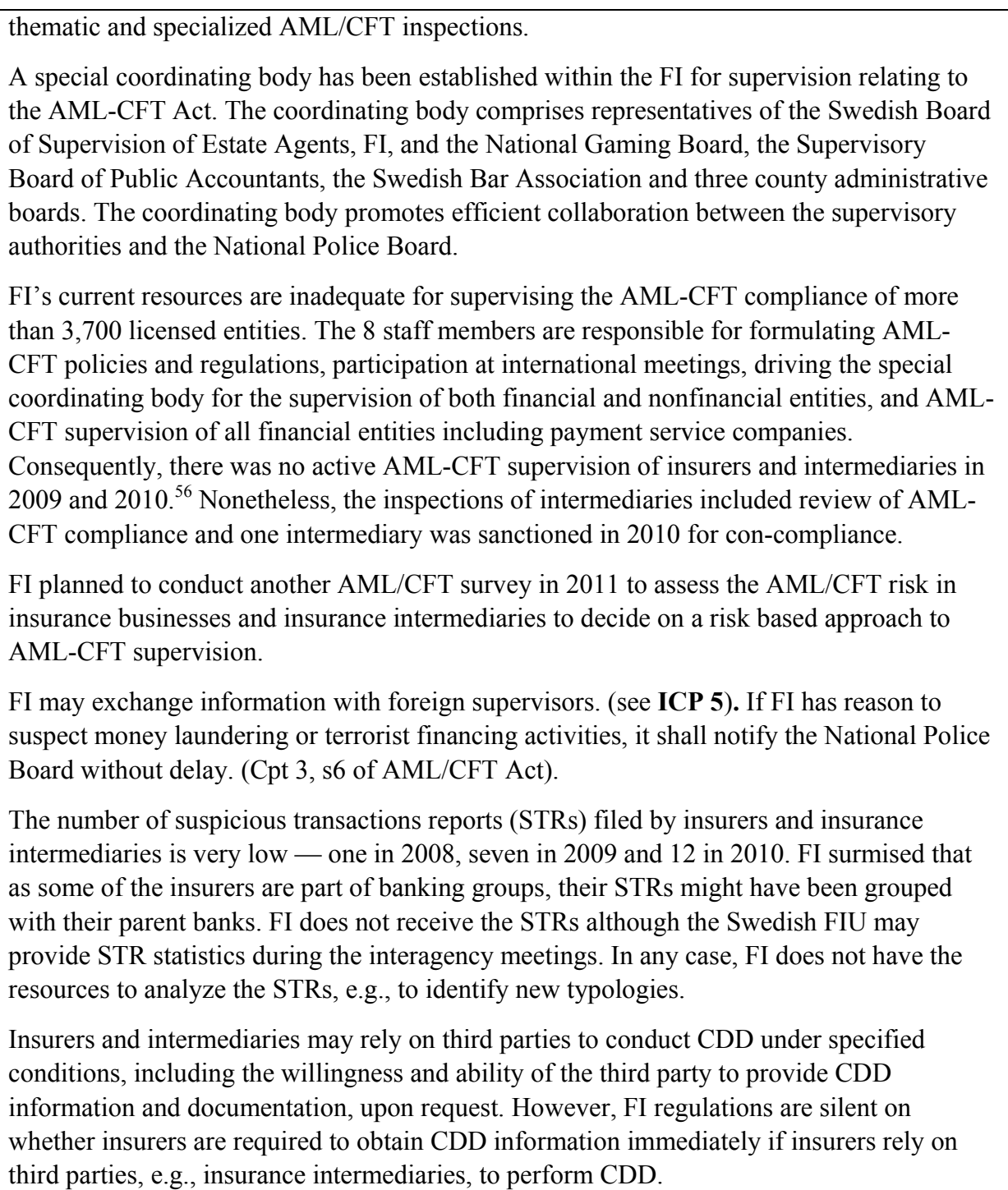 \\
\hline Assessment & Largely Observed \\
\hline Comments & $\begin{array}{l}\text { Recent FATF follow-up report has noted that Sweden has taken measures to bring } 18 \text { out of } \\
\text { the } 20 \text { recommendations previously rated partially compliant or noncompliant to at least a } \\
\text { level equivalent to largely compliant. More supervisory resources are needed to ensure } \\
\text { effective supervision of AML-CFT compliance by insurers' and insurance intermediaries. } \\
\text { The authorities are advised to: } \\
\text { a) review the adequacy of resources for AML-CFT supervision; and } \\
\text { b) update the legal requirements where insurers rely on intermediaries to perform CDD. }\end{array}$ \\
\hline
\end{tabular}

\footnotetext{
${ }^{56}$ In 2006, FI conducted a survey of 126 financial companies on a cross-sectoral basis. Each company had to respond to approximately 80 questions concerning their AML/CFT regime. Through this exercise, FI assessed levels of compliance and the possible risks. Review of all 828 insurance intermediaries in 2006 resulted in many insurance intermediaries having to make corrections to their internal procedures for AML/CFT. In 2007, on-site inspections of three major life insurers led to corrections to their internal procedures for AML/CFT.
} 
APPENDIX I. KEY RECOMMENDATIONS OF THE 2002 FSAP AND THEIR IMPLEMENTATION

\begin{tabular}{|c|c|}
\hline Recommendations & Reported Action \\
\hline $\begin{array}{l}\text { Strengthen staff resources in order to fulfill FI's legal } \\
\text { tasks }\end{array}$ & $\begin{array}{l}\text { While staff resources have increased since } 2002 \text {, } \\
\text { more may be needed in certain areas. }\end{array}$ \\
\hline $\begin{array}{l}\text { Introduce reporting requirements on outsourcing } \\
\text { arrangements and guidelines to auditor. }\end{array}$ & $\begin{array}{l}\text { Not implemented. FI reviews insurers } \\
\text { outsourcing, especially in major insurers/groups. }\end{array}$ \\
\hline $\begin{array}{l}\text { Enhance licensing requirements including clarifying } \\
\text { and extending fit and proper test to senior } \\
\text { management/key persons of insurers. }\end{array}$ & $\begin{array}{l}\text { Not implemented. Requirements apply only board } \\
\text { members and the CEO. }\end{array}$ \\
\hline $\begin{array}{l}\text { Require mandatory annual reports on risk } \\
\text { management report by insurers }\end{array}$ & $\begin{array}{l}\text { Submission is not mandatory. FI reviews such } \\
\text { information in supervising major groups and } \\
\text { undertakings. }\end{array}$ \\
\hline $\begin{array}{l}\text { Review the normal distribution assumption used for } \\
\text { analyzing technical provisions of nonlife insurers. }\end{array}$ & $\begin{array}{l}\text { FI's current practice is no longer dependent on } \\
\text { any probability distribution. }\end{array}$ \\
\hline $\begin{array}{l}\text { Establish disclosure requirements for derivatives and } \\
\text { off-balance sheet items. }\end{array}$ & Not implemented. Work is in progress. \\
\hline $\begin{array}{l}\text { Implement supervisory procedures to ensure } \\
\text { compliance with market conduct requirements. }\end{array}$ & $\begin{array}{l}\text { Compliance is part of FI's supervisory focus. } \\
\text { Insurers have to appoint compliance officers. }\end{array}$ \\
\hline Set up a legal basis for issuing a formal criticism. & FI is empowered to do so. \\
\hline Enhance reporting by actuaries. & $\begin{array}{l}\text { Not implemented. The role of the responsible } \\
\text { actuary is limited by the IBA. }\end{array}$ \\
\hline Supervise branches of Swedish insurers in the EEA. & $\begin{array}{l}\text { Swedish branches in the EEA are supervised, } \\
\text { subject to resources available. }\end{array}$ \\
\hline $\begin{array}{l}\text { Safeguard confidentiality of information shared by } \\
\text { other supervisors. }\end{array}$ & $\begin{array}{l}\text { Confidentiality is observed on a level acceptable } \\
\text { to all parties involved. }\end{array}$ \\
\hline
\end{tabular}

